\title{
Floods in the
}

Skagit River Basin

Washington

GEOLOGICAL SURVEY WATER-SUPPLY PAPER 1527

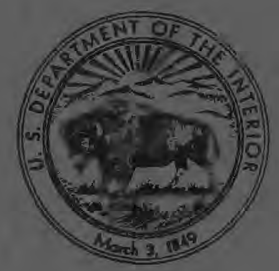




\section{IAN 221962 \\ Floods in the \\ Skagit River Basin \\ Washington}

By JAMES E. STEWART and G. LAWRENCE BODHAINE

GEOLOGICAL SURVEY WATER-SUPPLY PAPER 1527

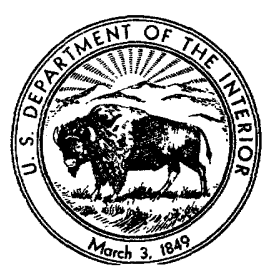


UNITED STATES DEPARTMENT OF THE INTERIOR

STEWART L. UDALL, Secretary

\section{GEOLOGIGAL SURVEY}

Thomas B. Nolan, Director

The U.\$. Geological Survey Library has cataloged this publication as follows :

Stewart, James E 1933-

Floods in the Skagit River basin, Washington, by James E. Stewart and G. Lawrence Bodhaine. Washington, U.S. Govt. Print. Off., 1961.

v, 65 p. illus., maps (part fold., part col. in pocket) diagrs., tables. $24 \mathrm{~cm}$. (U.S. Geological Survey. Water-supply paper 1527)

Bibliography : p. 63.

1. Floods-Washington (State)-Skagit River basin. 2. Stream measurements-Washington (State) I. Bodhaine, George Lawrence, 1917- joint author. II. Title. (Series) 


\section{CONTENTS}

Page

Abstract

Introduction.......... 1

Description of the basin

Geography

Climate........ 6

Geology ...

Description of floods.......... 9

Winter floods .

Summer floods . .

Duration of peaks.

Short-duration flood of November 1949

Long-duration flood of February 1951...

Effect of reservoirs ..........

Dikes on lower Skagit River . .

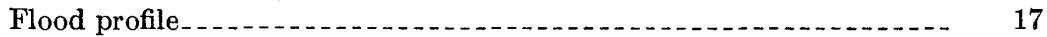

Flood plain $\ldots \ldots$

Flood damage

History of floods. . 20

Historic flood data...

Indian legend flood of about $1815 \ldots \ldots \ldots$

Tree-staining flood of about $1856 \ldots$

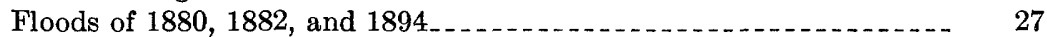

Flood of November $1897 \ldots \ldots \ldots$

Flood of November 1909 _ . 28

Flood of December 1917

Flood of December 1921

Flood of February $1932 \ldots$

Flood of November 1949

Flood of February 1951

Flood records. . . .

Gaging station records. .

Skagit River near Hope, British Columbia_._._. . . . . . . 32

Skagit River above Devils Creek, near Newhalem, Wash...... 32

Beaver Creek near Newhalem, Wash........ 33

Skagit River near Newhalem, Wash_...

Ruby Creek below Panther Creek, near Newhalem, Wash._._._ 34

Skagit River below Ruby Creek, near Newhalem, Wash_._._... 35

Ross Reservoir near Newhalem, Wash...................... 35

Thunder Creek near Newhalem, Wash._._.

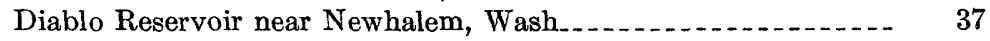

Skagit River at Reflector Bar, near Newhalem, Wash_........ 38

Stetattle Creek near Newhalem, Wash. ................. 39

Skagit River at Newhalem, Wash........................ 40 
Flood records-Continued

Gaging station records-Continued

Skagit River above Alma Creek, near Marblemount, Wash....-

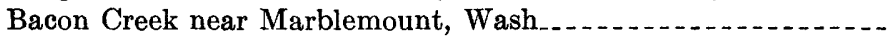

Skagit River at Marblemount, Wash.........

Cascade River at Marblemount, Wash......................

South Fork Sauk River near Barlow Pass, Wash..............

Sauk River above Whitechuck River, near Darrington, Wash...

Sauk River at Darrington, Wash . . . . .

Suiattle River near Mansford, Wash . . . .

Sauk River near Sauk, Wash

Baker River below Anderson Creek, near Concrete, Wash......

Lake Shannon at Concrete, Wash.....

Baker River at Concrete, Wash....

Skagit River near Concrete, Wash.........

Alder Creek near Hamilton, Wash. . .

Day Creek near Lyman, Wash.....

Skagit River near Sedro Woolley, Wash.....................

East Fork Nookachamps Creek near Clear Lake, Wash.........

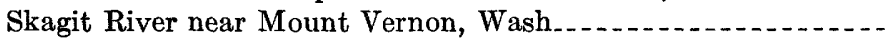

Frequency of floods.

Single station frequency

Frequency series...

Plotting positions...

Historical data

Fitting frequency graphs

Regional frequency .

Selection of base period .

Comparable means. . . . . .

Test for homogeneity

Combining records

Flood-frequency relationships

Flood-frequency curves....

Selected bibliography

Index

\section{ILLUSTRATIONS}

Plate 1. Map of Skagit River basin showing location of gaging stations

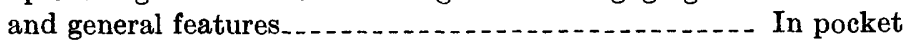

2. Map of Skagit River basin showing major dike failures_- In pocket

3. Views of the flood of 1951 in vicirity of Conway, Wash

4. Views of the flood of 1951 near Mount Vernon and

Hamilton . . . . . . .

Figure 1. Hydrographs of short duration flood peaks...

2. Hydrographs of long-duration flood peaks..... 13

3. Capacity curve for Ross Reservoir.....

4. Hydrograph showing effect of dams on flood peaks........ 16

5. Flood profiles.

6. Map showing area probably inundated by major flood...... 19 
FigdRe 7. Composite flood-frequency curve, Skagit River basin....... 58

8. Variation of mean annual flood with drainage area........ 60

9. Frequency of annual floods, Skagit River at Newhalem, Wash_ 61

10. Frequency of annual floods, Cascade River at Marblemount, Wash

11. Frequency of annual floods, Sauk River at Darrington, Wash_

12. Frequency of annual floods, Baker River below Anderson

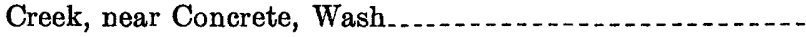

13. Frequency of annual floods, Skagit River near Concrete, Wash

14. Frequency of annual floods, Skagit River near Sedro Woolley, Wash 



\title{
FLOODS IN THE SKAGIT RIVER BASIN, WASHINGTON
}

\author{
By James E. Stewart and G. Lawrence Bodhaine
}

\begin{abstract}
\end{abstract}
According to Indian tradition, floods of unusually great magnitude harassed the Skagit River basin about 1815 and 1856. The heights of these floods were not recorded at the time; so they are called historical floods. Since the arrival of white men about 1863, a number of large and damaging floods have been witnessed and recorded.

Data concerning and verifying the early floods, including those of 1815 and 1856 , were collected prior to 1923 by James E. Stewart. He talked with many of the early settlers in the valley who had listened to Indians tell about the terrible floods. Some of these settlers had referenced the maximum stages of floods they had witnessed by cutting notches at or measuring to high-water marks on trees. In order to verify flood stages Stewart spent many weeks finding and levelling to high-water marks such as drift deposits, sand layers in coves, and silt in the bark of certain types of trees.

Gaging stations have been in operation at various locations on the Skagit River and its tributaries since 1909 , so recorded peak stages are available at certain sites for floods occurring since that date. All peak discharge data available for both historical and recorded floods have been listed in this report.

The types of floods as to winter and summer, the duration of peaks, and the effect of reservoirs are discussed.

In 1899 Sterling Dam was constructed at the head of Gages Slough near Sedro Woolley. This was the beginning of major diking in the lower reaches of the Skagit River. Maps included in the report show the location of most of the dike failures that have occurred during the last 73 years and the area probably inundated by major floods. The damage resulting from certain floods is briefly discussed.

The report is concluded with a brief discussion of the U.S. Geological Survey method of computing flood-frequency curves as applied to the Skagit River basin. The treatment of single-station records and a means of combining these records for expressing regional significance are exemplified. Historical data are used in the development of both the single-station and the regional curves.

\section{INTRODUCTION}

Skagit River, the largest in northwestern Washington, rises in the main Cascade Range and empties into Skagit Bay near Mount Vernon. The total drainage area is about 3,100 square miles, of which 400 square miles are in Canada. A map of the area shows location and general features on plate 1. 
The date of the first exploration of the Skagit Valley is unknown, but Hudson's Bay and Northwestern fur trappers probably started working the Skagit Valley about 1810. The first white settlement on the delta at Mount Vernon occurred about 1863. The actual settlement of the valley upstream from the delta started about 1878 when gold was discovered on Ruby Creek, which empties into the Skagit River at the point where the river starts to break through the secondary Cascade barrier. With the impetus of excitement over gold, there was a comparatively rapid influx of population to the whole valley. However, the gold-boom settlement of about 5,000 people on Ruby Creek died out within a very few years. The main increases in permanent valley population have occurred since the Northern Pacific Railway pushed northward across the Skagit delta in 1890 , and have been attributable mainly to logging and lumbering, mining, and agriculture.

The Skagit River valley has a history of floods that dates from about 1815. The basin has been subjected to several damaging floods since the year 1863 when it was first settled by white men. Indian legends indicate that even greater floods occurred in the nineteenth century prior to 1863 . The exact elevations of all of these floods are not known, but their relative magnitudes have been fairly well determined by intensive research and study in the valley. A brief resume of the floods is as follows:

1. About 1815: Highest flood.

2. 1856: Second highest flood.

3. 1880,1882 , and 1894: Spring floods that inundated lower valley for long period.

4. November 16, 1896: Highest flood since the settlement of the valley in or about 1878 and probably the highest since 1856.

5. November 19, 1897: Floods everywhere higher than the 1896 flood, especially high from the mouth of the Cascade River to just below Birdsview. In general, in this section of the river the 1897 peak has not been exceeded to date (1958). The 1897 flood rose with remarkable suddenness, due to a very warm Chinook wind and heavy rain. The Cascade, Sauk, and Baker Rivers were very high and caused a high peak in the Skagit River near the mouth of each stream. Owing to the sudden starting and stopping of flood conditions, the peaks were rapidly reduced by channel storage as the crest moved downstream.

6. November 16, 1906: Flood exceeded the 1897 flood in the diked districts on the delta, because of the dikes. In all other sections of the river the flood of 1906 was lower than that of 1897 .

7. November 30, 1909: Since the settlement of the valley, this flood has exceeded all floods from the headwaters in Canada to the mouth of the Cascade River; the same is true from just below Birdsview to the sea, except where $\log$ jams forced the floods of 1897 and 1921 to higher elevations.

8. December 30, 1917: Flood was remarkable for the length of time it remained high, rather than for its peak stage. Comparable to 1896 and 1906 flood in regard to height. The damage on the delta was due partly to the long flood period producing a great deal of overflow after the dikes had broken. 


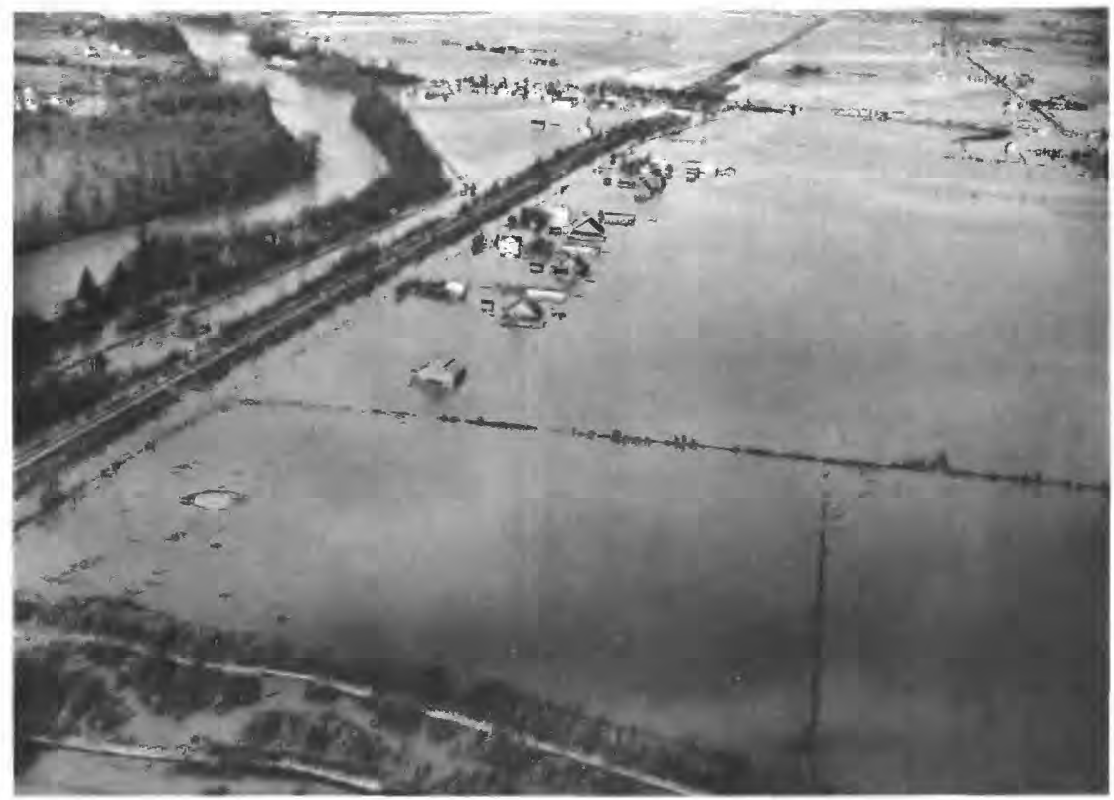

$A$, Aerial view of Conway and vicinity.

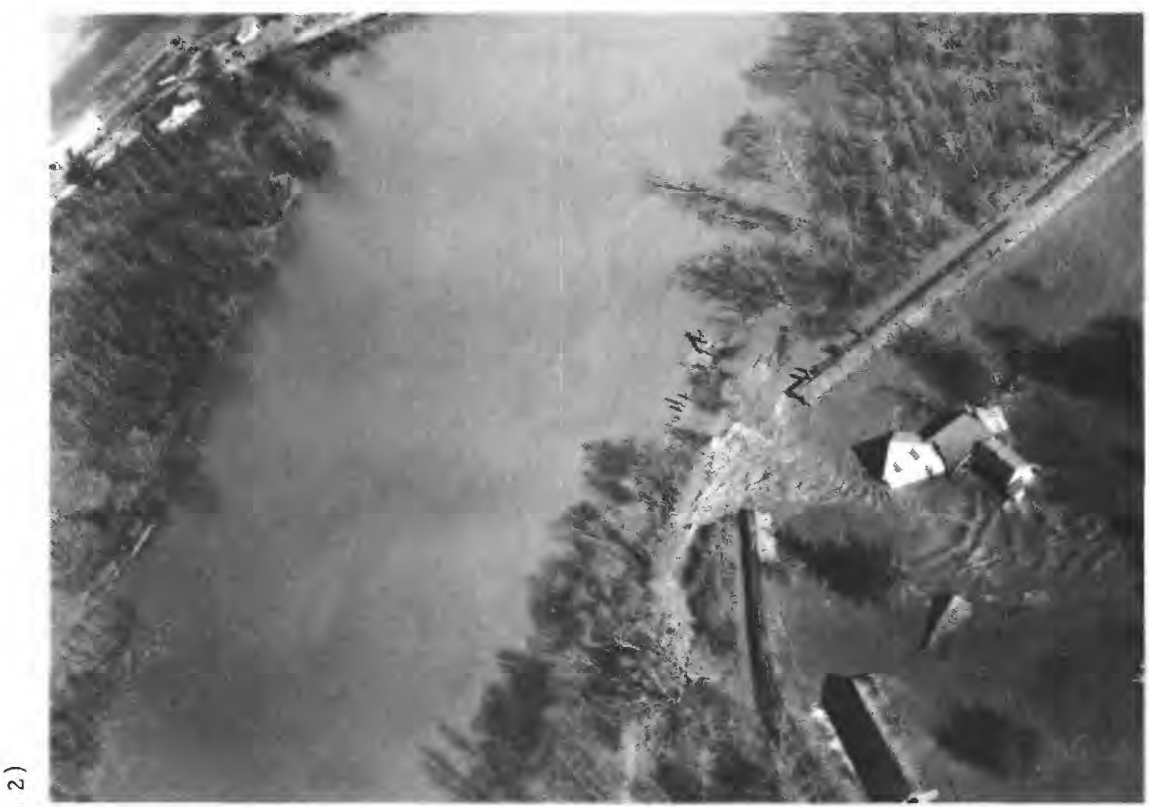

$B$, North Fork distributary below the bridge on U.S. Highway 99, showing the break in the dike. Photographs by U.S. Army Corps of Engineers.

\section{FLOOD OF 1951 IN VICINITY OF CONWAY, WASH.}




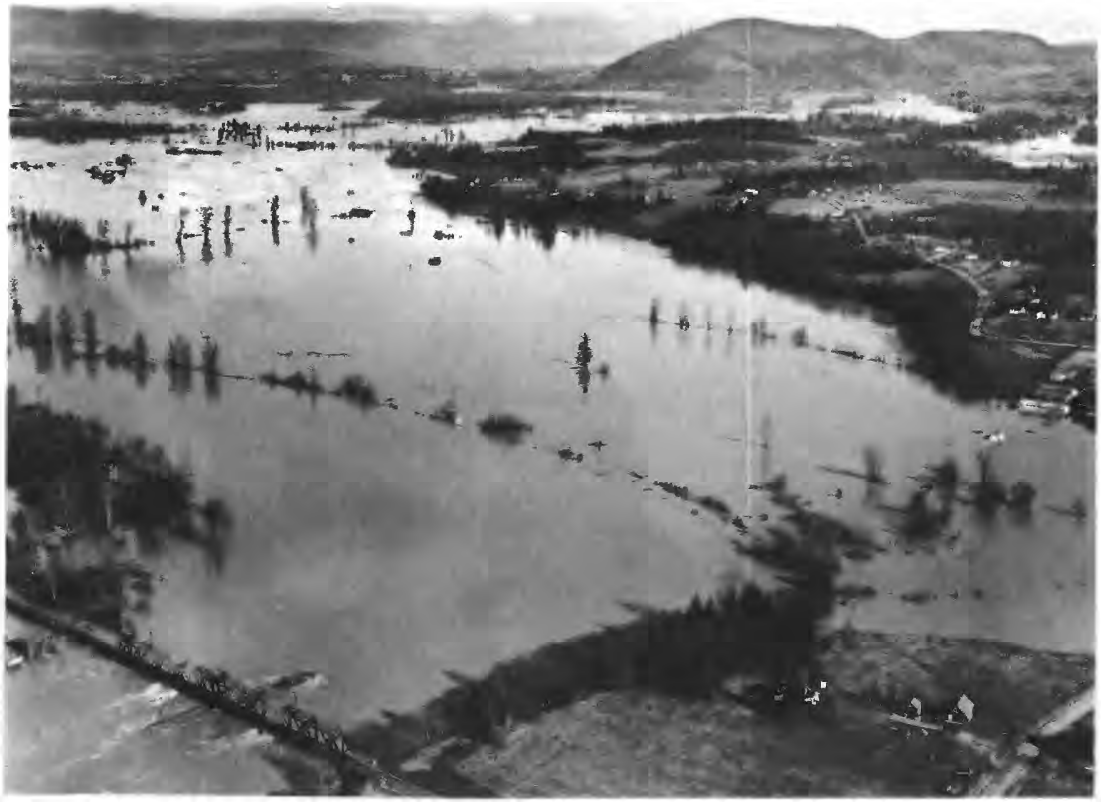

$A$, View upstream from Great Northern Railway bridge north of Mount Vernon.

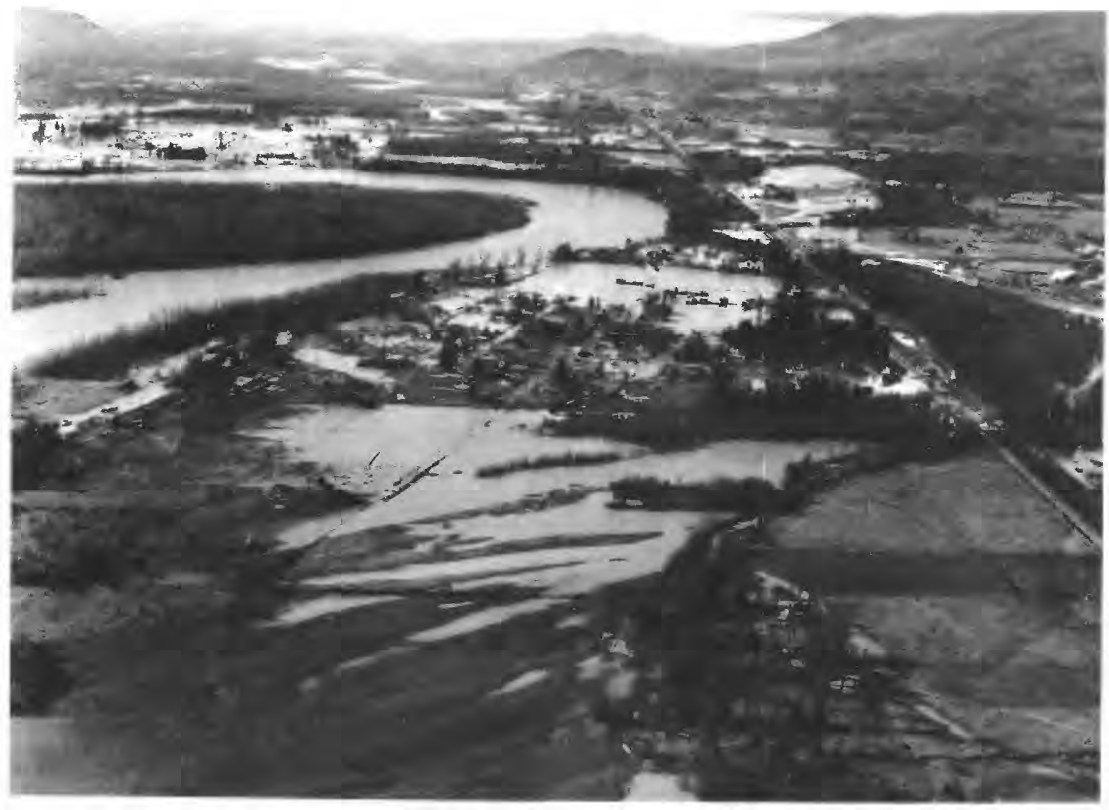

$B$, Aerial view of town of Hamilton and valley downstream. Photographs by U.S. Army Corps of Engineers.

\section{FLOOD OF FEBRUARY 1951 IN VICINITY OF MOUNT VERNON AND HAMILTON, WASHINGTON}


9. December 12, 1921: Flood was nearly as great as the flood of 1909 and in most of the basin was higher than the flood of 1917 .

10. February 1932: Flood would have been much more serious if there had been no upstream storage. Peak at gaging station on Skagit River (in a canyon known locally as "The Dalles") near Concrete was estimated to have been reduced by 35,000 efs. Natural discharge at The Dalles estimated to be about 40,000 efs less than the 1917 flood.

11. November 1949: Upstream storage estimated to have reduced the peak at The Dalles near Concrete by 45,000 efs. Under natural conditions this flood probably would have been greater than the 1932 flood and onlv slightiy smaller than the 1917 flood.

12. February 1951: Estimated natural discharge less at The Dalles near Concrete than for any of the above floods. Because of the long duration of this flood, the crest reaching Mount Vernon had been reduced very little by channel storage and exceeded the 1949 flood at that location by about 2.5 feet.

Major floods have caused considerable monetary damage, especially in the lower reaches of the valley. Estimates of known flood losses compiled by the U.S. Army Corps of Engineers total $\$ 4,850,000$ from 1894 to 1932 . The number of lives lost is not known.

Floods of recent years have been less damaging because they have been of lesser magnitude and the power dams in the upper reaches of the river have provided some storage.

In 1922, as a result of damage from the 1921 and earlier floods, there was a desire by those suffering damage to have studies initiated as a preliminary step to possible flood protection measures. Dikes had been built to confine the lower reaches of the river but they offered protection only against the lesser floods. The first logical step was to determine the size of the floods to be controlled. Representatives of Skagit County made arrangements with G. L. Parker, then district engineer of the U.S. Geological Survey Surface Water Branch at Tacoma, to determine the sizes of the floods. J. E. Stewart was given the assignment of compiling field data and writing a preliminary report, which was completed in 1923 but not published.

In the study for the 1923 report, redeterminations were made of the peak discharge of such floods as had occurred on the streams in the area since the beginning of streamflow records. Also, approximate calculations were made of the peak discharge of all the great floods that occurred between the time of the first white settlement of the Skagit Valley and the beginning of the streamflow records. In addition, field investigations and computations were made of the stage, discharge, and approximate dates of two great floods that occurred prior to the arrival of the first white settlers. The conclusion was reached that the earlier and greater of these two floods probably was as large or nearly as large as the greatest flood that has occurred here within the last several hundred years. Information of floods, occurring before 1863, 
was handed down orally by the Indians, and by finding silt and stains in the bark of trees and sand deposits in protected coves along the stream.

The 1923 report recommended that certain areas be given early flood protection and that a warning system be installed. Also, suggestions were made as to some preliminary steps toward permanent flood protection. The pertinent data from the report written by J. E. Stewart are included in this report. Interest in the report was revived in 1942 by F. M. Veatch, who succeeded G. L. Parker as district engineer. As a result, some work on it was done in the Washington office during the next few years, chiefly by W. S. Eisenlohr, Jr. In 1949 additional field data were obtained, and work was resumed to evaluate previous data. Most of this report was written by G. L. Bodhaine, Tacoma district. He used the basic data and reports of J. E. Stewart and recent data concerning floods in the Skagit River basin.

The present report contains discussions of many features bearing on the magnitudes of past and present floods, of the geologic history as it may affect floods and flood evidence, and of dike failures and inundated areas. It also contains a regional flood-frequency study based on the methods most recently developed by the U.S. Geological Survey.

Good photographs of the earlier historic floods are not available, but pictures were obtained by the U.S. Army Corps of Engineers during the flood of February 1951. These pictures were taken at noon a few hours after the peak, which occurred at about 7 a.m. on February 11 near Mount Vernon, and are presented as plates 3 and 4 .

The photographs on plate 3 were taken in the area of the distributaries near the mouth of the river where dike breakage occurred. Plate $3 A$ shows the inundated area in the town of Conway and vicinity. Levee break on the North Fork distributary is shown in plate $3 B$.

Plate $4 A$ shows the inundated area between the railroad bridge north of Mount Vernon (just upstream from the gaging station near Mount Vernon) and the town of Sedro Woolley. The flood at the town of Hamilton, about 12 miles upstrean from Sedro Woolley, is shown in plage $4 B$.

\section{DESCRIPTION OF THE BASIN}

\section{GEOGRAPHY}

The Skagit River may properly be said to head in Skaist Creek, its most upstream tributary, of which the most northerly branch begins on the slopes of Skaist Mountain in British Columbia, Canada, about 20 miles north of the international boundary. From there, the river flows in a generally southwestward direction for about 25 miles; thence about 7 miles in a generally southeastward direction to a point 
about 2 miles north of the international boundary; thence in a generally southward direction to a place in the State of Washington about 20 miles south of the international boundary, where it turns southwestward and begins to break through the Skagit Range.

Through the Skagit Range the river flows in a deep, narrow, steep, and almost continuous canyon about 10 miles long. This section of the river is now the center of a great hydroelectric-power project of the city of Seattle. The project involves three major developments; namely, Ross (formerly Ruby), Diablo, and Gorge.

The Ross development at the head of the canyon involves a dam that, when completed, will raise the water more than 600 feet and create a reservoir with capacity of $3,450,000$ acre-feet, completely controlling the normal river flow below that point and a powerhouse that ultimately will have a capacity of 360,000 kilowatts. At present, the dam is 540 feet high, provides $1,400,000$ acre-feet of storage, and supplies water to 3 generators producing a total of 270,000 kilowatts.

The Diablo development is located at about the center of the 10mile section of canyon. It involves a dam that raises the water 325 feet and backs it to the toe of Ross dam, but there is a reservoir capacity of only 90,000 acre-feet because of the narrowness of the canyon. A powerplant of 132,000 kilowatt capacity has been completed and is in operation.

The Gorge powerplant now has a capacity of 108,000 kilowatts. The development consists of a temporary masonry diversion dam and 11,000 feet of 20.5-foot diameter tunnel which furnishes a head of 294 feet at the powerhouse. The temporary diversion dam is now being replaced by a permanent dam more than 100 feet high which will back water to the toe of Diablo dam but will provide only about 6,000 acre-feet of storage. The head on the Gorge plant will thereby be increased to 385 feet and the plant capacity, including the additional units being installed, will be 153,000 kilowatts.

The foregoing developments, mainly Ross, will materially reduce flood flows downstream and particularly reduce the smaller floods.

The drainage area where the river emerges from its canyon section at the Gorge powerplant is about 1,160 square miles. After leaving the canyon section, the Skagit River within a distance of 20 miles is enlarged by the Cascade, the Sauk, and the Baker Rivers, its three largest tributaries. Near the mouth of the Sauk River, the Skagit River changes its general direction from southwest to west. It emerges upon its delta plain about 35 miles farther downstream near the city of Sedro Woolley, where the drainage area is about 3,000 square miles. At Sedro Woolley, the river again changes its course to southwest and flows along the southeastern and landward side of its delta. Finally, it divides into typical delta distributaries and 
empties into Skagit Bay which lies nearly east of the Straits of Juan de Fuca. The Skagit River delta is about 45 miles south of the international boundary.

The following table shows the locations of various features with respect to the mouth of the Skagit River at Skagit Bay:

\begin{tabular}{|c|c|c|c|}
\hline Location & $\begin{array}{l}\text { Miles } \\
\text { above } \\
\text { mouth }\end{array}$ & Location & $\begin{array}{l}\text { Miles } \\
\text { above } \\
\text { mouth }\end{array}$ \\
\hline $\begin{array}{l}\text { Mouth at Skagit Bay } \\
\text { North Fork distributary } \\
\text { Mount Vernon } \\
\text { Gage near Mount Vernon } \\
\text { Nookachamps Creek } \\
\text { Gage near Sedro Woolley } \\
\text { Day Creek } \\
\text { Alder Creek } \\
\text { Birdsview } \\
\text { Gage near Concrete } \\
\text { Baker River } \\
\text { Sauk River } \\
\text { Cascade River } \\
\text { Gage at Marblemount } \\
\text { Bacon Creek }\end{array}$ & \begin{tabular}{r|}
0.0 \\
7.0 \\
10.2 \\
14.5 \\
17.4 \\
21.1 \\
34.1 \\
40.2 \\
44.3 \\
52.6 \\
55.0 \\
65.7 \\
76.6 \\
77.2 \\
81.4
\end{tabular} & $\begin{array}{l}\text { Gage above Alma Creek } \\
\text { Gage at Newhalem } \\
\text { Gorge Dam } \\
\text { Stetattle Creek } \\
\text { Gage at Reflector Bar } \\
\text { Diablo Dam } \\
\text { Thunder Creek } \\
\text { Ross Dam } \\
\text { Gage below Ruby Creek } \\
\text { Ruby Creek } \\
\text { Gage near Newhalem } \\
\text { Beaver Creek } \\
\text { Gage above Devils Creek } \\
\text { International boundary } \\
\text { Gage near Hope, B.C }\end{array}$ & $\begin{array}{r}84.2 \\
92.2 \\
95.3 \\
98.5 \\
99.3 \\
99.6 \\
100.9 \\
103.8 \\
104.0 \\
104.8 \\
106.0 \\
108.8 \\
116.1 \\
134.0 \\
138.8\end{array}$ \\
\hline
\end{tabular}

Many times in the past, the river in its lower course, even upstream from the delta, has abandoned its channel and many of these abandoned channels remain as sloughs through which a little water flows, even during low river stages.

\section{CLIMATE}

The climate of the North Pacific coastal region, in which lies the greater portion of the Skagit basin, is mild and moderately moist owing to the prevailing westerly air currents that advance inland from the Pacific Ocean, and to the shielding effects of the Cascade Range, which serve to exclude and deflect the cold continental air towards the east. The prevailing westerly air currents cross vast reaches of the ocean, and acquire much water vapor and a temperature near that of the sea. The air currents receive their warmth and moistness from the general currents of the ocean rather than from the Japanese current, the Kuroshio, which curves northward into Alaskan waters. As a result of the rather steady influx of marine air the winters are comparatively warm and the summers cool. Extremes of heat or cold are moderate and of short duration, and the daily range of temperatures is small.

The main river valley lies very nearly along latitude $48^{\circ} 30^{\prime}$ which is slightly north of the northern tip of Maine and approximately in the latitude of St. Johns, Newfoundland. The midwinter temperatures are similar to those on the Atlantic coast at latitudes several hundred miles farther south.

Heavy rains or snows, especially in winter, occur when the moistureladen winds encounter the cool higher altitudes of the Coast and 
Cascade Ranges. Large quantities of snow seldom fall at sea level. During especially warm winter weather, rain may prevail up to elevations of nearly 6,000 feet. When combined with melting snow, the rains often result in severe floods in the lower, heavily settled section of the Skagit River valley.

The climatological stations within the Skagit basin are, in general, at low elevations; therefore, the actual temperature and precipitation at high elevations are not known. The following table shows meteorological data for stations in the Skagit basin, including data for the warmest, coldest, wettest, and driest months:

\begin{tabular}{|c|c|c|c|c|c|c|c|}
\hline \multirow{2}{*}{ Station } & \multirow{2}{*}{$\begin{array}{c}\text { Elevation } \\
\text { in feet } \\
\text { above mean } \\
\text { sea level }\end{array}$} & \multicolumn{3}{|c|}{$\underset{\left({ }^{\circ} \mathrm{F}\right)}{\text { Mean temperature }}$} & \multicolumn{3}{|c|}{$\begin{array}{l}\text { Mean precipitation } \\
\text { (inches) }\end{array}$} \\
\hline & & Jan. & Aug. & Annual & July & Dec. & Annual \\
\hline $\begin{array}{l}\text { Anacortes. } \\
\text { Sedro Wooley } \\
\text { Concrete } \\
\text { Skagit Powerplant } \\
\text { Darrington. }\end{array}$ & $\begin{array}{r}30 \\
56 \\
270 \\
525 \\
550\end{array}$ & $\begin{array}{l}39.1 \\
37.7 \\
35.2 \\
33.5 \\
34.1\end{array}$ & $\begin{array}{l}61.6 \\
62.1 \\
64.9 \\
65.8 \\
62.6\end{array}$ & $\begin{array}{l}50.6 \\
50.4 \\
50.9 \\
50.3 \\
48.7\end{array}$ & $\begin{array}{l}0.67 \\
1.36 \\
1.13 \\
1.29 \\
1.27\end{array}$ & $\begin{array}{r}4.00 \\
6.35 \\
9.32 \\
12.00 \\
13.63\end{array}$ & $\begin{array}{l}26.6 \\
45.5 \\
60.8 \\
72.6 \\
76.0\end{array}$ \\
\hline
\end{tabular}

The average annual depth of runoff from the Skagit basin above Concrete is about 74 inches. Therefore, the average annual rainfall over the basin must be about 94 inches because evaporation, transpiration and other losses generally are considered to consume approximately 20 inches of the rainfall in this type of country.

The upper or southward-flowing section of the Skagit River and its tributary basin lie between ridges of the Cascade Range and are somewhat isolated from the coastal marine climate. The minimum altitude of that section of the river is about 1,200 feet; and, consequently, the winter snow is retained until spring and summer to a greater extent than in the lower section of the river. Furthermore, before reaching the upper part of the basin, the atmosphere, in passing over the first ridges of the Cascade Range, becomes considerably depleted of its heat and moisture. As a result of the natural isolation afforded the upper part of the basin, the runoff is much less than from the lower area. For comparison the runoff at several gaging stations for the period 1941-55 is listed below:

Station

Skagit River near Hope.

Skagit River at Newhalem

Skagit River near Concrete

Skagit River near Mount Vernon.

Sauk River near Sauk

Cascade River at Marblemount

Baker River at Concrete

$\begin{array}{rr}\begin{array}{c}\text { Runoff } \\ \text { (inches) }\end{array} & \begin{array}{c}\text { Drainage area } \\ \text { (square miles) }\end{array} \\ 38.6 & 357 \\ 50.1 & 1,160 \\ 74.2 & 2,700 \\ 70.7 & 3,060 \\ 81.5 & 714 \\ 80.9 & 171 \\ 115.2 & 297\end{array}$


Several prominent mountain peaks border the Skagit basin in the ramifying branches of the Cascade Range. The two highest peaks are Mount Baker, 10,800 feet, and Glacier Peak, 10,400 feet. Several peaks are more than 9,000 feet and many more than 8,000 feet. Owing to the high altitude and heavy precipitation, the higher peaks are mantled with glaciers and snow fields which are productive of a heavy runoff during the summer and fall periods of low rainfall.

\section{GEOLOGY}

Prior to the glacial epochs, the Sauk and Suiattle Rivers formed a part of the Stillaguamish drainage basin.

During the glacial ages, the Skagit basin was much more heavily mantled with local ice than at present. In addition, the Skagit delta was overrun by an invasion of ice from Canada. The Canadian ice sheet, augmented by local glaciers in the State of Washington, pushed southward through the Puget Sound area between the Cascade Range and the Coast Ranges until it passed latitude $47^{\circ} \mathrm{N}$, and established its terminal moraine a short distance north of Centralia, nearly 170 miles south of the Canadian border. The Skagit River was blocked not only by this tremendous glacier near its mouth, but also further upstream near the town of Concrete where a large local glacier came down the Baker River valley.

The dam formed by one of the glaciers forced the Skagit River to cross a pass, now occupied by the lower Sauk valley, into the Suiattle River basin. During a portion of this glacial epoch, while the ice dam held, the entire Skagit River above Concrete poured across the Skagit-Suiattle divide and thence down the Stillaguamish River. The ice dam probably held for many thousands of years and during this time the Skagit-Suiattle pass was rapidly cut down to form a regular river channel. After the glacial epoch, the Skagit River returned to its old lower valley and was able to capture the Suiattle and Sauk Rivers from the Stillaguamish River through the new channel cut through the Skagit-Suiattle divide.

In the Puget Sound region there were great changes in elevation during the glacial epochs. Geologists have stated that during various geologic eras this region probably has been as much as 1,000 feet higher and perhaps 300 feet lower than it is at the present time. During the various glacial actions the stream valleys became deeply filled with glacial drift. It may be nearly 1,000 feet to bedrock in the old river channel on the Skagit delta. Construction projects have shown about 110 feet of depth to bedrock at Gorge Dam and about 30 feet to bedrock at Ross Dam.

The most abundant rocks in the Skagit valley between Marblemount and Sedro Woolley are unmetamorphosed andesite and basalt 
associated with unmetamorphosed to slightly metamorphosed sedimentary rocks such as slate, greywacke and subordinate amounts of limestone, and low-grade metamorphosed equivalents, such as phyllite and green schist. All these rocks are pre-Tertiary. Tertiary sandstones are less abundant. There are local small outcrops of serpentinite. Higher up in the valley-from Marblemount up-are metaquartz diorite, schist with minor serpentinite pods, quartz diorite and granodiorite, and gneiss of the Skagit volcanic formation of Daly (1912).

In many places the sandstones are completely covered by glacial debris. Throughout the valley, there are many clay deposits in the hillsides. Some coal is present in the lower reaches of the valley.

\section{DESCRIPTION OF FLOODS}

The Skagit River is subject to two distinct types of floods-winter and summer. In the past, most of the exceptional winter floods have occurred in November or December; the summer floods in May or June.

The largest flood during the winter of 1878-79 occurred on March 17,1879 , and the largest flood during the winter of 1914-15 occurred on April 2, 1915. Since the arrival of the first white settlers, these two floods, produced by factors that ordinarily bring about winter floods, occurred on the latest dates known for winter floods.

The earliest date that a crest of a true summer flood is known to have occurred was May 11, 1910. A recent early summer flood occurred on May 13, 1949. On the basis of the assumption that these are the latest winter and the earliest summer floods that are likely to occur, a time interval of about a month is all that exists between the two types of floods.

In summer when the lowlands are overflowed, the crops are damaged by the long continued high stages of the snow-melt floods. However, winter floods cause the greatest overall damage because the crest heights of the winter floods are higher on the average than those of the summer floods.

\section{WINTER FLOODS}

Large winter floods in the Skagit River basin are caused by water released through the action of strong and long-continued winds which bear warm moistureladen atmosphere from the Pacific Ocean to the Cascade Range; this action causes precipitation and snowmelt. These winds are known locally, at least, as "chinook" winds and are caused by air currents blowing toward the center of an area of low barometric pressure. 
Dr. Charles F. Brooks, secretary of The American Meteorologic Society, in No. 117 of "Why the Weather," states,

The chinook is the warm wind of the northwest. Its name is that of a tribe of Indians from the direction of whose camp the warm southwest wind reached the trading post, Astoria, at the mouth of the Columbia River. The use of the name soon spread to all warm winds in winter in the Northwest; and now the term is applied mostly to warm winds descending onto the Great Plains after passing over the Rocky Mountains.

Precipitation is produced during a chinook when the air currents, as they are being forced up and over a mountain barrier, reach a higher altitude than the condensation level.

The floodwater released through the action of a chinook is composed of both rainwater and water from melted snow and ice. The rainwater and part of the water from snow and ice are from precipitation that occurs during the chinook in the form of rain, snow, and sleet. The remainder of the floodwater results from the melting of old snow and ice, which consists not only of snow but also of rainwater that has been absorbed and entrapped by the snow during earlier occurrences of precipitation.

A rainfall-runoff study for the Skagit River, based on discharge records at Sedro Woolley and precipitation records in the upper part of the basin, at and near Reflector Bar, was made by J. E. Stewart. This study shows that during the years 1909-23 the average yearly runoff in inches at Sedro Woolley was very nearly equal to the average precipitation at the upper basin sites. This indicates that a much heavier precipitation must have occurred at higher altitudes in order to provide the additional amount of water lost through evaporation, transpiration, retention, and ground water. These data show extremely heavy precipitation and high runoff during the months in which the greater floods occurred. For example, the precipitation in November 1909 was 27.7 inches and the runoff was 12.5 inches; in December 1917 the precipitation was 29.8 inches (7.4 inches occurring December 27-29) with a runoff of 14.1 inches; and in December 1921, 12.8 inches of precipitation (10.21 inches occurring December 10-12) produced a runoff of 13.3 inches, which indicates the melting of large quantities of snow accumulated during the previous two months of heavy precipitation. These examples show that winter floods result almost entirely from the large quantities of precipitation that occur during a storm, but are supplemented to some extent by the melting of previously deposited snow.

Four of the highest floods for which the exact date of occurrence is known were in November in the years 1896, 1897, 1906, and 1909. Two other high floods occurred in December in 1917 and 1921. Precipitation records at Vancouver, Wash., show that the great flood of 1856 also occurred in December. 
The flood profiles of the great winter floods vary in shape depending upon the length of time the flood lasts (short- or long-duration storm) and on the time of day the flood crests from the larger tributaries enter the main river channel.

\section{SUMMER FLOODS}

The crests of summer floods are caused mainly by the hot summer sun melting the glaciers and the snowfields in the high sparsely timbered or open areas. The crests of the summer floods are probably swelled to a minor degree by snowmelt from the heavily timbered regions which lie just below the glaciers and adjacent snowfields.

The peak stages of the greatest summer floods are considerably lower than those for the great winter floods. The summer floods, however, are of much longer duration and are greater in volume than the winter floods. The crops are growing at the time of summer floods and, if the dikes break, the great damage done is accentuated by the fact that the long duration and great volume of the floods prevent repairing of the dikes. The greatest summer flood was that of 1894 comparing closely with those of 1880 and 1882 . For two weeks the flood of 1894 remained higher than the highest peak of any of the recent summer floods. The flood of 1880 remained at a high stage for more than a month.

\section{DURATION OF PEAKS}

The duration of the flood peaks in the upper part of Skagit River is an important factor in determining whether the flood will be destructive in the lower reaches. This may be especially true of the large floods that do not quite reach the stages and discharges of the known great floods. The peaks of the floods of November 1949 and February 1951 were selected to demonstrate this point. The peaks would have been considerably higher had there been no storage in the power reservoirs upstream, but this would not affect the comparison of the duration of the two peaks.

\section{SHORT-DURATION FLOOD OF NOVEMBER 1949}

The flood of November 1949 is a good example of the flattening of a flood crest as it moves downstream. The hydrographs of the peak that occurred at the gaging stations near Concrete and near Mount Vernon are shown in figure 1. Channel storage had a marked effect on the sharpness of the peak by the time the crest reached Mount Vernon. The peak discharge of 153,000 cfs near Concrete was reduced to 114,000 near Mount Vernon.

Precipitation records in the basin at time of this flood partly explain the reduction in crest in the lower reaches of the channel. The Sedro Woolley precipitation gage indicates that very little rainfall occurred 


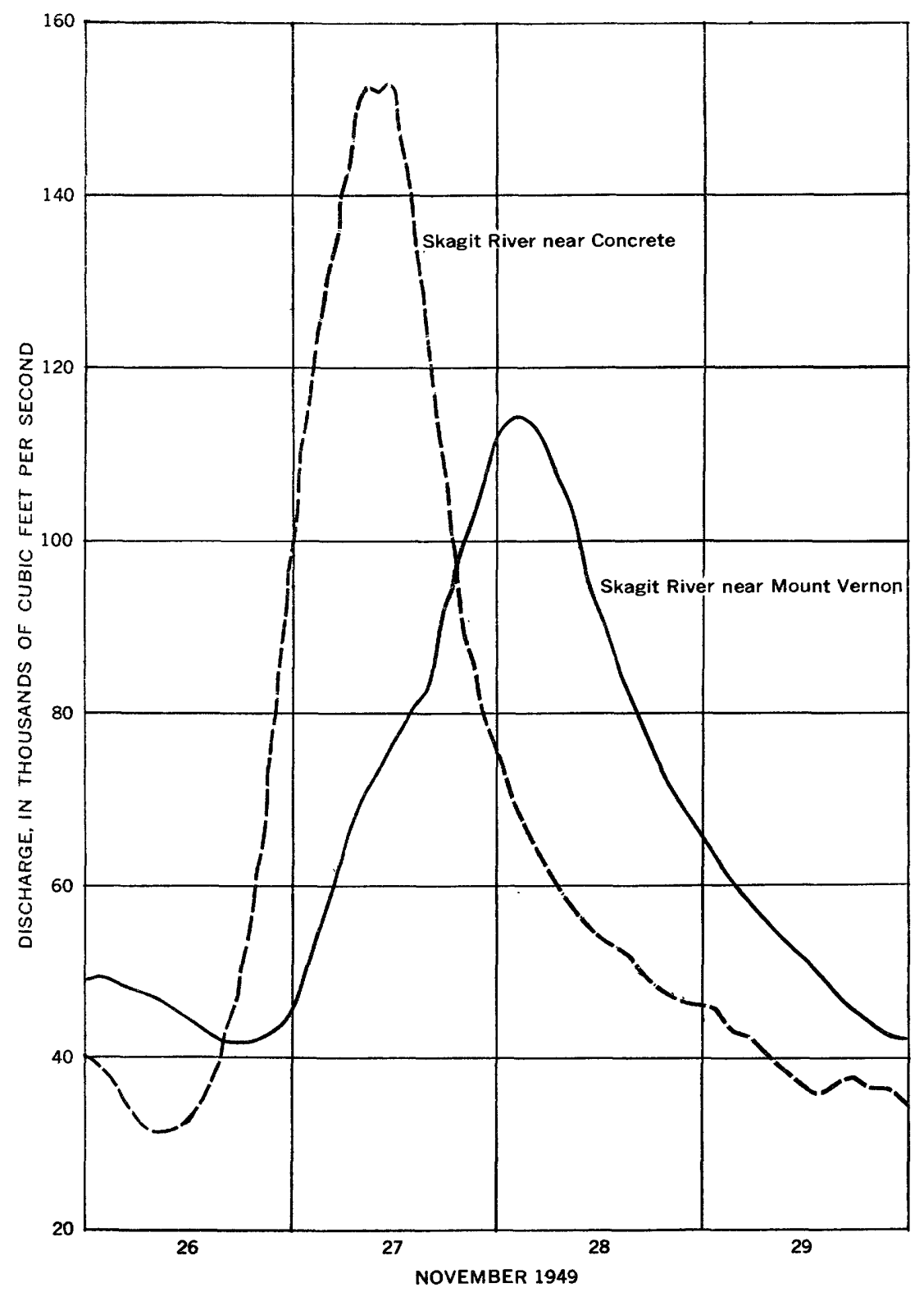

FIGURE 1.-Hydrographs of short-duration flood peaks.

in the lower part of the basin. Weather records show that there was no snow on the ground as far upstream as Diablo Dam, and that the minimum and maximum temperatures at Diablo Dam were $39^{\circ}$ and $58^{\circ}$, respectively. The precipitation data are shown in the following table: 


\begin{tabular}{|c|c|c|c|c|c|}
\hline \multirow{2}{*}{ November 1949} & \multicolumn{5}{|c|}{ Precipitation, in inches } \\
\hline & Diablo Dam & $\begin{array}{c}\text { Skagit } \\
\text { powerplant }\end{array}$ & $\begin{array}{l}\text { Marble- } \\
\text { mount }\end{array}$ & Concrete & $\begin{array}{l}\text { Sedro } \\
\text { Woolley }\end{array}$ \\
\hline $\begin{array}{l}23 \\
24 \\
25 \\
27 \\
28 \\
29\end{array}$ & $\begin{array}{l}2.00 \\
1.50 \\
1.67 \\
.95 \\
4.05 \\
.71 \\
.67\end{array}$ & $\begin{array}{r}1.03 \\
.93 \\
.68 \\
4.21 \\
.72 \\
.60 \\
.46\end{array}$ & $\begin{array}{r}0.65 \\
.60 \\
.75 \\
2.57 \\
1.18 \\
.81 \\
.17\end{array}$ & $\begin{array}{r}0.43 \\
.32 \\
1.17 \\
1.43 \\
1.73 \\
.46 \\
.20\end{array}$ & $\begin{array}{l}0.09 \\
.37 \\
.46 \\
.28 \\
.32 \\
.29 \\
.09\end{array}$ \\
\hline
\end{tabular}

1 Peak near Concrete.

2 Peak near Mount Vernon.

LONG-DURATION FLOOD OF FEBRUARY 1951

The flood of February 1951 is a good example of a flood crest of long duration. The peak near Concrete lasted many hours longer than the peak of November 1949 although it did not reach as great a discharge. The hydrographs of the crests that occurred at the gaging stations near Concrete and near Mount Vernon are shown on figure 2. It can be

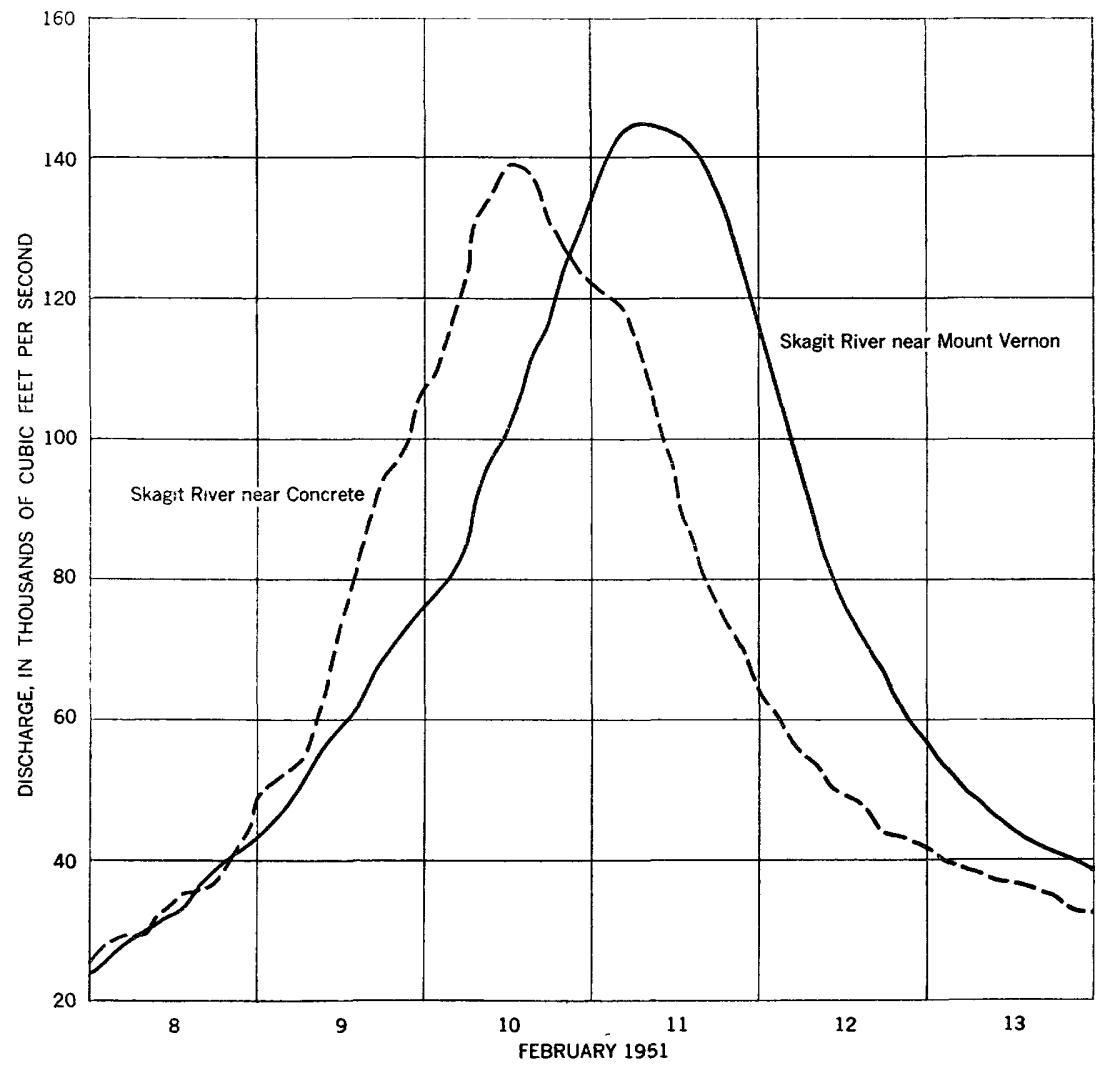

FjaURE 2.-Hydrographs of long-duration flood peaks. 
seen that the duration of the peak reduced the effect of channel storage and that the peak downstream was increased by a large contribution from the low elevations.

Weather records show that on February 7, 15 inches of snow was on the ground. By February 11 this was reduced to 5 inches. No snow was on the ground at or downstream from Concrete. The temperature at Diablo Dam during the flood ranged from a minimum of $33^{\circ}$ to a maximum of $53^{\circ}$. The precipitation data are shown in the following table:

\begin{tabular}{|c|c|c|c|c|c|}
\hline \multirow{2}{*}{ February 1951} & \multicolumn{5}{|c|}{ Precipitation, in inches } \\
\hline & Diablo Dam & $\begin{array}{c}\text { Skagit } \\
\text { powerplant }\end{array}$ & $\begin{array}{l}\text { Marble- } \\
\text { mount }\end{array}$ & Concrete & $\begin{array}{l}\text { Sedro } \\
\text { Woolley }\end{array}$ \\
\hline $\begin{array}{l}8 \\
10 \\
11\end{array}$ & $\begin{array}{l}1.82 \\
2.61 \\
6.21 \\
3.76 \\
.61\end{array}$ & $\begin{array}{l}0.67 \\
1.39 \\
3.02 \\
5.77 \\
2.89 \\
\text { T }\end{array}$ & $\begin{array}{l}\text { 1. } 54 \\
2.29 \\
\text { 4. } 67 \\
2.76 \\
0.43\end{array}$ & $\begin{array}{l}1.03 \\
.80 \\
2.42 \\
1.10 \\
1.11 \\
0\end{array}$ & $\begin{array}{r}0.42 \\
.50 \\
1.83 \\
1.11 \\
.28\end{array}$ \\
\hline
\end{tabular}

1 Peak near Concrete.

2 Peak near Mount Vernon.

The large amount of precipitation in the lower reaches of the basin accounts for a part of the increase in peak discharge as the flood progresses downstream. Snowmelt would have added materially to the peak, if snow had been on the ground when the rain began.

\section{EFFECT OF RESERVOIRS}

The reservoirs in the upper Skagit River basin have had a material effect on the peak discharge of the river occurring since the dams were constructed. The dam on Baker River at Concrete was constructed in 1926 and has had an effect on many peak flows in Skagit River. Diablo Dam was constructed in 1930, and practically all peaks since that date have been reduced somewhat by storage in Diablo Reservoir. The first level in the construction of Ross Dam was completed in 1940, and all peaks since that date have been affected to some degree by storage in Ross Reservoir. By August 1949, Ross Dam had been raised two more levels and was capable of reducing the peak to a great extent on all but the largest floods at that point. If Ross Dam is ever raised to its proposed ultimate height, another 125 feet, it will be capable of almost completely controlling the entire flow from the 980 square miles of the Skagit River drainage basin upstream from the dam. The amount flood peaks would be diminished is not known, but it may be assumed that the flow of all except extreme peaks would be considerably reduced. In all probability even peak flows as great as those of 1815 and 1856 would be reduced by an appreciable amount. 


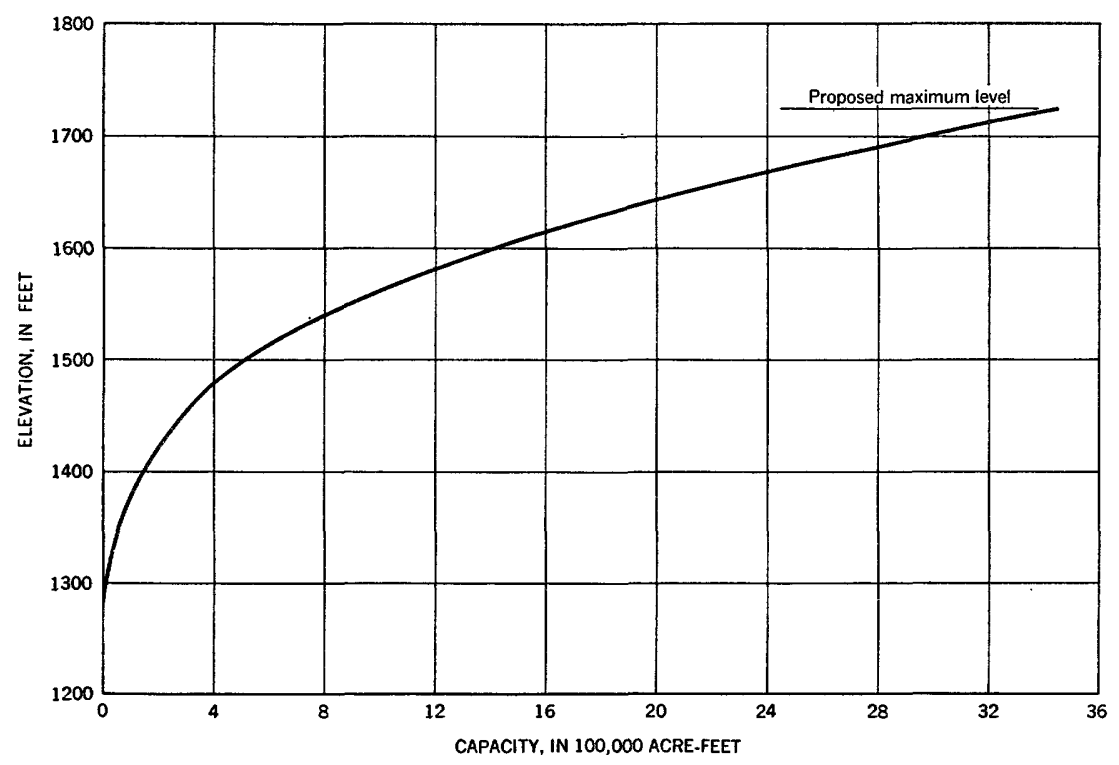

FIGURE 3.-Capacity curve for Ross Reservoir.

The storage capacity curve for Ross Reservoir at the present height of Ross Dam is shown in figure 3. The capacity at watersurface elevation 1,600 feet is 1,400,000 acre feet. The additions of only 125 feet of height, to elevation 1,725 feet, would increase the capacity to $3,450,000$ acre-feet, or to more than double its present capacity.

During the floods of November 1949 and February 1951, Lake Shannon was held at practically a constant level at the time of the peaks, so the Baker River peaks were not appreciably reduced by storage. However, during both floods Diablo and Ross Reservoirs stored large volumes of flow, and the peak discharges on the Skagit River at the gaging station near Concrete were substantially reduced. It has been estimated that the peak flow of the November 1949 flood at the gage near Concrete was reduced by $45,000 \mathrm{cfs}$ owing to storage in the two main-stem reservoirs. This indicates a natural peak discharge of $200,000 \mathrm{cfs}$ near Concrete which probably would have been of disastrous proportions in the lower valley even if the effect of channel storage on the sharp peak was considered. An estimate has been made that the peak discharge of the February 1951 flood at the gage near Concrete was reduced 13,000 cfs by upstream storage. If this flow had not been stored, it probably would have increased the peak at Sedro Woolley and at Mount Vernon to about $158,000 \mathrm{cfs}$ as a result of the long peak, which also might have proved disastrous to the lower valley. The crest of the February 1951 flood 
was at the top of the dikes in several places so an additional 13,000 cfs probably would have caused a failure at some point.

A study of the effect of upstream storage on the peak of the February 1932 flood at the gaging station near Concrete was made by G. L. Parker. Figure 4 shows the computed results. Diablo Dam and Baker Dam were the only ones in existence in the basin at that time, but their reservoirs apparently reduced the peak by a large amount. Diablo Reservoir stored about 26,000 cfs of the peak flow and Lake Shannon accounted for about 35,000 cfs which shows a total reduction of $61,000 \mathrm{cfs}$. This peak, also, could have produced disastrous results downstream under natural conditions.

The more recent floods have been quite small in comparison to the great floods of the past. Even though the present dams could con-

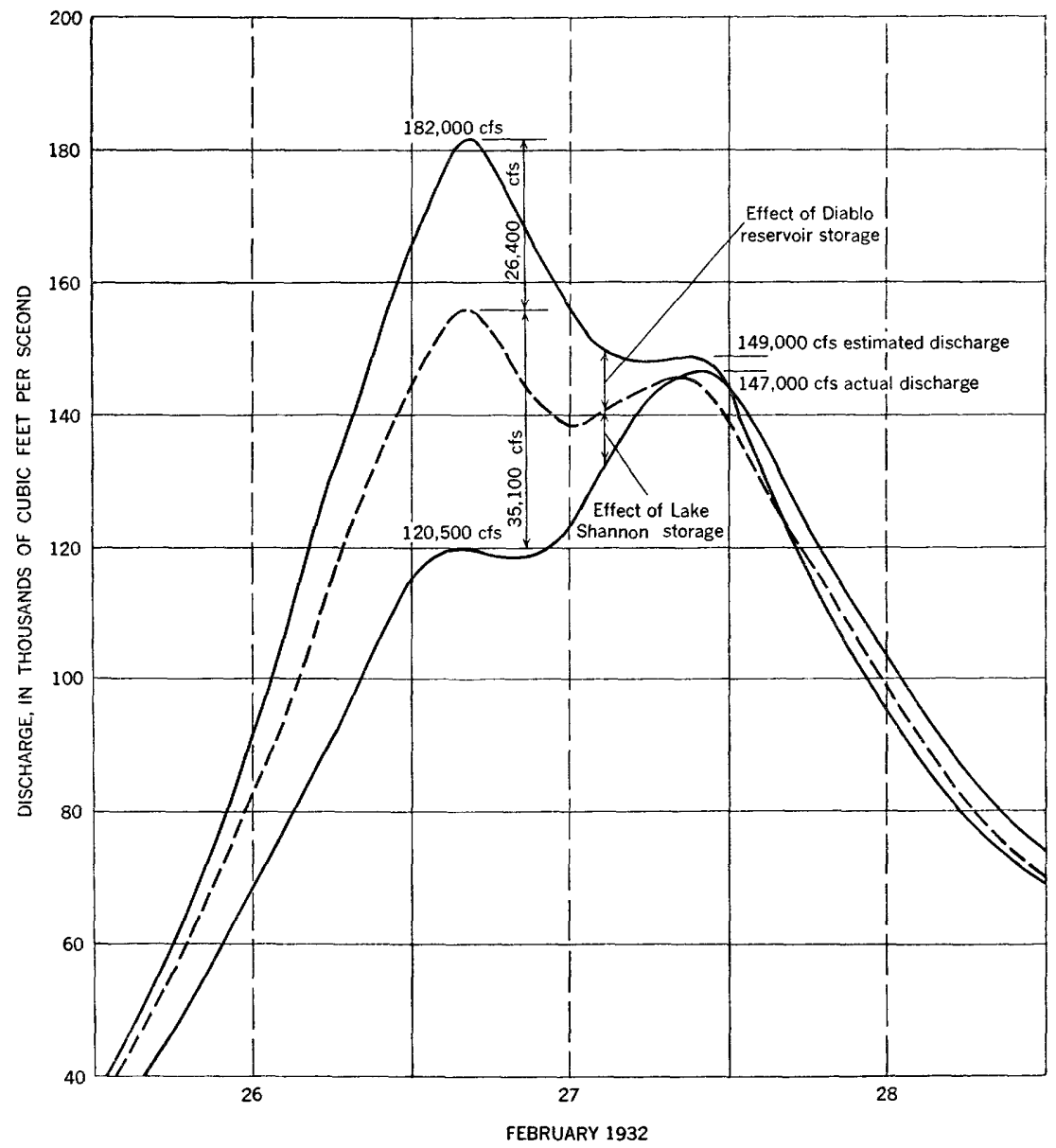

Frodre 4.-Hydrographs showing effect of dams on flood peak. 
ceivably reduce a great peak by many thousands of cubic feet per second, the total peak discharge of an extreme flood would be so great as to cause tremendous damage to the valley, especially to the area west of Sedro Woolley.

\section{DIKES ON LOWER SKAGIT RIVER}

Diking is known to have been practiced in the lower reaches of Skagit River in the early 1890's. In general, it was due to the efforts of individuals who were interested in keeping the summer floods away from their seeded farm land. Some areas near the river mouth were completely surrounded by dikes at an early date. In the beginning, the dikes were not very high but were raised to a sufficient elevation to confine minor floods to the river channel.

A map showing the locations of most of the major dike failures is shown as plate 2. Many breaks occurred downstream from Avon during the years 1894 and 1897.

In 1899 Sterling Dam was constructed at the head of Gages Slough which was a distributary of the Skagit River from the northern part of Sterling Bend. This was the commencement of major diking in the vicinity of Burlington and Sedro Woolley. Since that date, the entire river from near Burlington to Skagit Bay has been diked. These dikes have been strengthened almost continually and especially after each major flood.

During the February 1951 flood, the water surface was approximately at the top of the dike in two places near Burlington. Yet the peak discharge for this flood at the gaging station near Mount Vernon (at the highway bridge $1 \frac{1}{2}$ miles north of town) was only $144,000 \mathrm{cfs}$. This indicates the great possibility that future floods will breach these dikes and flood the lowlands. The dikes near the mouth did fail in several places in 1951.

The map of the lower reaches of Skagit River, plate 2, shows the location of most of the dike failures that have occurred during the last 73 years. From the location of these breaks, it is quite easy to determine approximately the areas that were inundated during each flood. The dike failures were not all detrimental to the landowners. Many dikes that normally protected low lying land along the shores of Puget Sound from salt water were breached to release Skagit River floodwater to Skagit and Padilla Bays, thereby preventing farmland from remaining submerged for a long period of time.

\section{FLOOD PROFILE}

Enough flood data are available to make a rough flood profile for the reach of channel from mile 7 to mile 21 (see log on page 6) and this profile can be extended to mile 50 (gage near Concrete). 


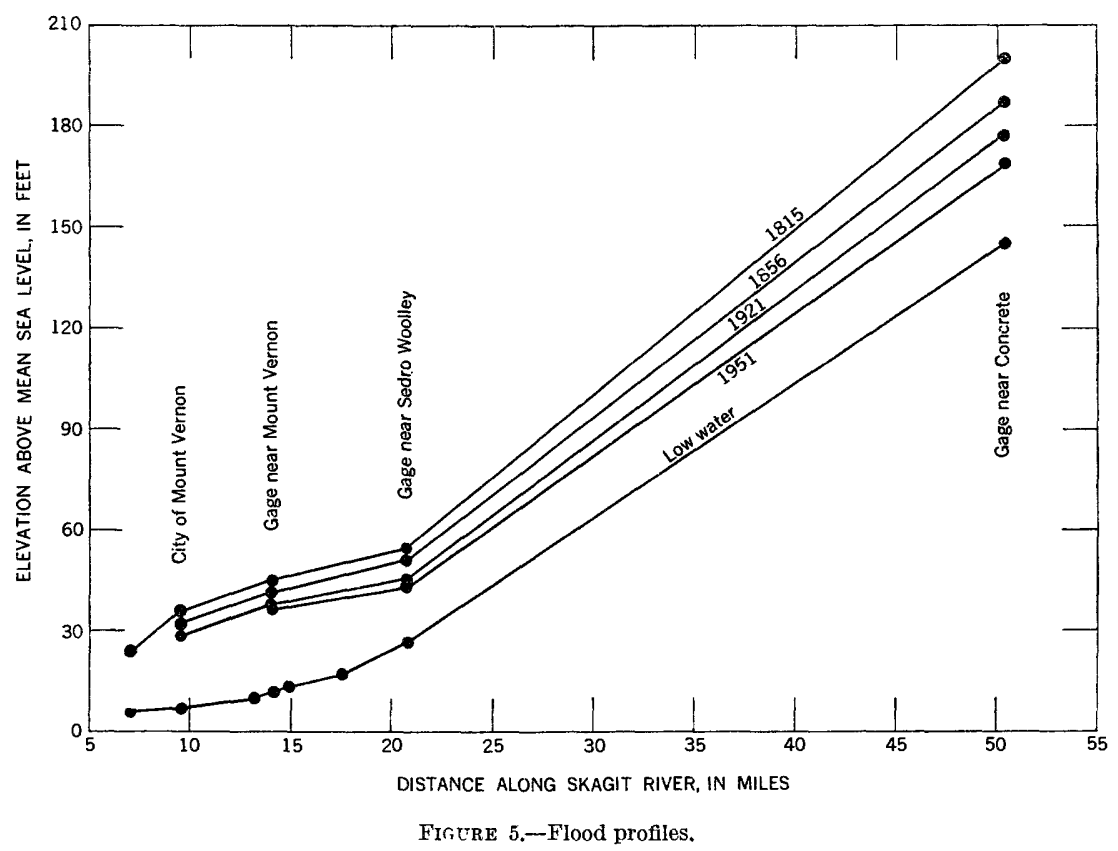

Profiles for several floods are shown on figure 5. These profiles were obtained from the Corps of Engineers, U.S. Army, and are based on data obtained from the Great Northern Railway Company. A 1951 flood was confined by the dikes throughout this reach of channel, so below Sedro Woolley its profile is not parallel with the profile for the 1921 flood when the dikes in this area failed.

\section{FLOOD PLAIN}

A map showing the area that probably would be inundated by floods of the magnitude of those that occurred in 1815 and 1856 is shown on figure 6 . Lesser floods would still cover a great part of this area as the flood of 1909 did inundate the greater part of it. This map was copied from a print of an old map obtained in 1945 from the Skagit County Engineer. The source of the map is unknown but it has been checked and found to be quite accurate in detail.

\section{FLOOD DAMAGE}

Considerable damage results from the greater floods in the valley. The area upstream from Concrete sustains a comparatively small amount of damage and the greatest amount occurs downstream from Sedro Woolley.

The U.S. Army Corps of Engineers, summarized the total flood damage at about $\$ 4,850,000$ for the floods of $1894,1906,1909$, 1917, 1921, and 1932. The two greatest losses were in 1894 and 1909 


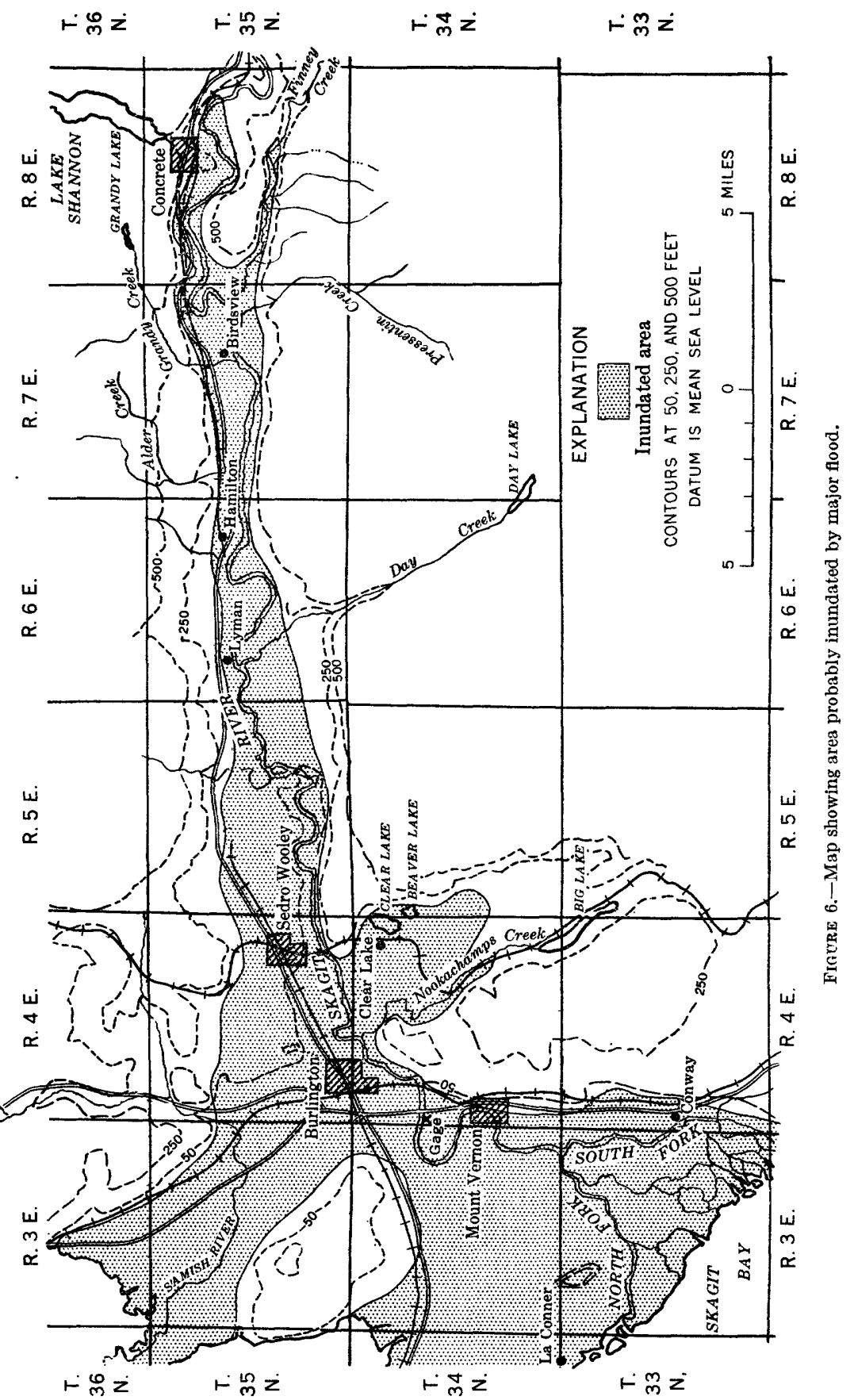


with estimates of $\$ 1,500,000$ for each flood. The average annual loss during the period 1894 to 1932 was $\$ 127,500$. The above figures were obtained from House Document 187, 73d Congress (U.S. Congress, House of Representatives, 1933).

The damage from the flood of 1949 has been estimated as $\$ 587,000$ based on 1951 prices. It is interesting to note that the 1909 flood damage, based on 1951 prices, has been estimated as $\$ 6,600,000$, or about 4 times the original figure. This shows that floods of great magnitude would now cause large monetary damage and have a serious effect on the economy of the valley.

\section{HISTORY OF FLOODS}

Settlers first arrived in Skagit Valley about 1878. At that time they noticed that the bark on all of the larger fir and cedar trees, and on all of the spruce trees more than 1.5 feet in diameter was stained up to a certain height. The cause of this staining was the subject of much discussion until, in 1879, one of the oldest Sedro Woolley Indians described how the trees had been stained by an extremely high flood that occurred when he was a small boy. ${ }^{1}$ The flood evidently made a deep impression upon him, because it came quickly and terribly one winter night. The flood probably caught the Indians asleep because in this old Indian's camp they barely escaped with their lives. They had no time to save their smoked salmon and dried venison. Apparently all the Indian camps along the river had the same experience because during that winter the Indians nearly starved. No doubt there was some loss of life, as there have been traditions handed down of drownings during the great flood.

From the estimated age of the Indian who remembered the flood, it was determined that this flood occurred between the years 1805 and 1825. The middle year of the period, 1815, is used as a convenient designation in referring to this flood of Indian legend.

The stain on the bark of the fir and cedar trees was quite clear in 1878 but it dimmed rapidly, so that by 1900, it was no longer noticeable except on a very few trees. From the rapid dimming of the stains it appears that those visible in 1879 must have been caused by a flood more recent than "about 1815." During the flood of 1909, Johnny Towne, an old Sauk Indian, told a white man that he had seen a much higher flood when he was a boy. In 1923 an Indian, thought to be 90 years old, told a Mr. James Cochraham that he remembered a flood several feet higher than the floods of 1909 and 1921. He did not remember any flood that had drowned Indians,

${ }^{1}$ Story was told to J. E. Stewart in June 1918 by Mr. Hart who lived on the right bank, between wagon and ratiroad bridges, in Sedro Wolley and had heard the Indian's story in 1879. 
although in his younger days he had known old Indians who remembered such a flood.

It would appear that a flood higher than that of 1909 had stained the fir and cedar trees prior to the coming of the white man but subsequent to the Indian legend flood of about 1815. Physical evidence of that flood was discovered in 1923 at The Dalles near Concrete. At that point there is a sandbar bench on the north side of the head of the canyon. The highest floods since the arrival of the white man have not covered this bar to a depth of more than two feet. On this bench were a number of young fir trees apparently all of the same age and much younger than the surrounding trees. A plausible explanation of this phenomena is that the bar was cleared of all trees during a large flood. In February 1923 one of the trees was cut down and found to have 62 rings at a stump height of 2.5 feet. It was estimated that it would take four years for such a tree to attain a height of 2.5 feet, and the tree would have been 66 years old in 1922, the last year of its growth. The flood that cleared the trees from the bar could have occurred as late as 1857, allowing a year for error, but probably occurred earlier. It is assumed that this flood caused the stains on the trees noted by the settlers in 1878 .

At Vancouver, Wash., precipitation records are available for the years $1849-68,1888-92$, and 1898 to date (1958). During these 80 years of record the total monthly precipitation exceeded 10 inches only 19 times, and with one exception, it was always in either November, December, or January. Of these 19 months of high precipitation, 6 occurred in the 6 -year period $1852-57$ with the total precipitation for 2 consecutive months exceeding 20 inches 4 times during this period. Although there may be little direct relation between precipitation in the Skagit River basin and that at Vancouver, Wash., yet such unusually heavy precipitation at a point even that close lends support to the evidence of a large flood on the Skagit River "about 1856."

From the description by early settlers, the flood of November 16, 1896, was the highest that had occurred since the beginning of the settlement in 1878. The heights of the intermediate floods in the springs of 1880,1882 , and 1894 and the fall seasons of 1879,1882 , 1883 , and 1887 are known only within a foot or two and principally in relation to the flood of 1896 .

The flood of November 19, 1897 was higher than the flood of 1896 at all points. It was especially high in the reach from Cascade River to a short distance below Birdsview where, in general, it remains the highest flood since 1878.

The flood of November 16, 1906 is not well remembered although it severely damaged the draw span of the Great Northern Railway 
bridge and destroyed one span of the highway bridge in Mount Vernon. It was on the latter bridge that a Mr. H. Peterson lost his life by running into the turning bar while trying to escape from the imperiled bridge. This flood was not so high as the flood of 1897 except in certain districts on the delta where the confining effects of the dikes caused higher stages.

The flood of November 1909 was the largest flood on the Skagit River since the coming of the white man in 1878, except for the reach from Cascade River to a short distance below Birdsview where it was surpassed by the flood of November 1897. Higher stages may also have occurred at other points during other floods as a result of log jams.

Evidence indicates that the flood of December 30, 1917 was comparable to those of 1896 and 1906 with respect to crest height. The damage on the delta was largely the result of the sustained flood flows inundating large areas after the dikes had broken.

The flood of December 12, 1921 was nearly as great as the flood of 1909 and was higher than that of 1917 except where some abnormal local condition prevailed.

It has been estimated that the natural discharge of the February 27, 1932 flood near Concrete (corrected for effect of upstream storage) would have been about the same as the discharge of the floods of 1896 and 1906 (U.S. Congress, 1933).

It has been estimated that the natural discharge of the November 27, 1949 flood near Concrete (corrected for effect of upstream storage) would have been about the same as the discharge of the 1917 flood.

The flood of February 10, 1951 reached a stage at the gage near Concrete only 1.8 feet lower than the flood of 1949 and 6.7 feetlower than the flood of 1917 .

The long period since 1921 without the occurrence of a destructive flood does not indicate that the chances of a devastating flood have decreased in any way. The size of floods to be expected in the future are discussed in sections on flood types and frequencies.

\section{HISTORIC FLOOD DATA}

The data for historic floods were taken directly from notes and statements of J. E. Stewart, the co-author of this publication. He spent considerable time in the field obtaining high-water marks and making studies of flood flows. Some of the statements in this section are similar to those made previously under the section on history, but they are repeated here in order to present the data on how the stages were obtained with other pertinent data concerning the floods.

Available data for the 1917 and 1921 floods are included in this section for comparative purposes. 
The gage heights for all floods at all stations are based on the maximum height reached by the surging water. This method became necessary because the height of all the earlier and some of the recent floods could be determined only in this manner. The resulting gage heights and discharges are somewhat greater than they would have been if the mean of the surges was used as is done at the present time. Data for several sites are given below.

Skagit River at Reflector Bar near Marblemount, Wash.

[See gaging station 10, page 38.]

\begin{tabular}{|c|c|c|c|c|}
\hline \multirow{2}{*}{ Date of flood } & \multicolumn{2}{|c|}{ Stewart's data } & \multicolumn{2}{|c|}{ Gaging station data } \\
\hline & $\begin{array}{c}\text { Elevation } \\
\text { (feet) }\end{array}$ & $\begin{array}{c}\text { Discharge } \\
\text { (cfs) }\end{array}$ & $\begin{array}{c}\text { Gage height } \\
\text { (feet) }\end{array}$ & $\begin{array}{l}\text { Discharge } \\
\text { (cfs) }\end{array}$ \\
\hline $\begin{array}{l}1815 \\
\text { November } 18,1897 \\
\text { November } 29,1909 \\
\text { December } 29,1917 \\
\text { December } 12,1921\end{array}$ & $\begin{array}{l}20.5 \\
18.5 \\
12.5 \\
15.4 \\
12.5 \\
14.5\end{array}$ & $\begin{array}{r}115,000 \\
95,000 \\
48,000 \\
70,000 \\
43,000 \\
63,000\end{array}$ & $\begin{array}{l}12.0 \\
14.1\end{array}$ & $\begin{array}{r}37,300 \\
58,000\end{array}$ \\
\hline
\end{tabular}

The flood dated 1815 probably occurred between 1805 and 1825 . This is based on the age of an Indian interviewed in 1879 concerning that flood.

The flood dated 1856 did not occur after 1857 and probably not before 1850. This is known by precipitation data and by the age of trees on a bench that was cleared by this flood.

The stages of the 1815 and 1856 floods were determined near the gage from the elevation of high-water marks on canyon walls and from flood sand deposited by those floods.

The stage of the 1909 flood was determined from drift and flood sand at, and upstream from, the gage.

Cascade River near Marblemount, Wash.

[This site is about 6 miles upstream from Cascade River at Marblemount, gaging station 16, page 42.]

\begin{tabular}{|c|c|c|}
\hline Date of flood & $\begin{array}{c}\text { Elevation } \\
(\text { feet })\end{array}$ & $\begin{array}{c}\text { Discharge } \\
(c f s)\end{array}$ \\
\hline & 22. 0 & 46,000 \\
\hline & 20.0 & 40,000 \\
\hline ber 29,19 & 15.0 & 26,000 \\
\hline ber $1917 \ldots$ & 17.2 & 32,000 \\
\hline
\end{tabular}

The 1909 flood peak was published in 1911 in Water-Supply Paper 272 (Stevens and others) as $31,700 \mathrm{cfs}$.

Early settlers stated that the river was much higher in 1897 than it was in 1909; also, that it was much higher in 1917 than in 1909.

The Cascade River emptied into the Skagit River at a point upstream from its present confluence until during the 1897 flood when its course was changed to the present location. 
Sauk River at Darrington, Wash.

[Gaging station 19, page 44.]

Date of flood

1815

1897

Date of flood

November 1909

December 29, 1917

$\begin{array}{rr}\begin{array}{c}\text { Elevation } \\ \text { (feet) }\end{array} & \begin{array}{c}\text { Discharge } \\ (\text { cfs })\end{array} \\ 18.0 & 48,000 \\ 17.0 & 44,000 \\ 16.0 & 40,000 \\ 15.0 & 36,000\end{array}$

Studies of river banks, including bars left from old channels, indicate that stages from 2 to 3 feet higher than 1917 have occurred. The flood of 1815 probably was not more than 1 foot higher than the 1897 flood.

The flood of 1897 was higher than the 1909 flood on the Cascade River to the north and the South Fork Skykomish River to the south, so it probably was higher on the Sauk.

The crest of the 1909 flood was obtained from a comparison by the gage observer of the relative stages of the 1909 and 1917 floods in his garden.

Baker River below Anderson Creek, near Concrete, Wash.

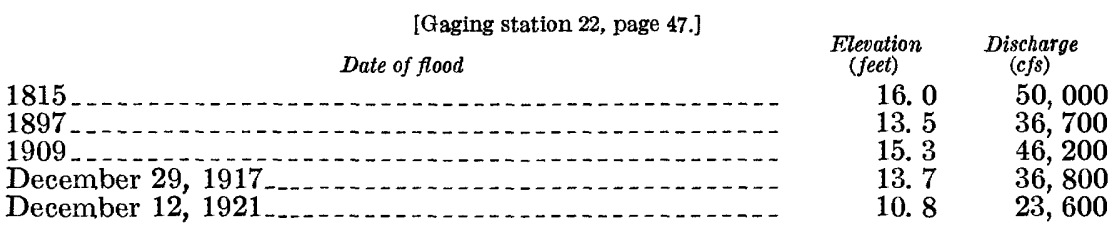

The great flood of 1815 probably reached a gage height of 16.0 feet.

The flood of 1897 probably was about the same height as the 1917 flood, or possibly slightly lower.

The crest of the 1909 flood was obtained from drift marks on trees and from the high water beach line.

Skagit River near Concrete, Wash.

[Gaging station 25, page 50.]

Date of flood

1815

1856

November $19,189 \overline{7}$

November 30,1909

December 30, 1917

December 13,1921

$\begin{array}{cc}\begin{array}{c}\text { Elevation } \\ (\text { feet })\end{array} & \begin{array}{c}\text { Discharge } \\ (\text { cfs })\end{array} \\ 56.6 & 500,000 \\ 44.6 & 350,000 \\ 38.4 & 275,000 \\ 36.4 & 260,000 \\ 33.0 & 220,000 \\ 34.9 & 240,000\end{array}$

The stage for the 1815 flood was determined from the maximum height of flood sand found just above The Dalles and about 300 feet upstream from the present gage.

The stage of the 1856 flood was determined from its high-water mark left on the canyon wall in The Dalles at the present gage site.

The floods of 1897 and 1917 have been dated on the assumption that the floods occurred shortly after midnight. 
The stages for the floods of 1897,1909 , and 1917 have been estimated from flood marks about 1 mile upstream. The stage of the 1897 flood is not as certain as the stages for the other two floods.

Skagit River near Sedro Woolley, Wash.

[Gaging station 28, page 52.]

Date of flood

1815

1856

November 16,1896

November 19,1897

November 16, 1906

November 30,1909

December 30, 1917

December 13, 1921

$\begin{array}{cc}\begin{array}{c}\text { Elevation } \\ (\text { feet })\end{array} & \begin{array}{c}\text { Discharge } \\ (\text { (cfs) }\end{array} \\ 63.5 & 400,000 \\ 60.0 & 300,000 \\ 54.8 & 185,000 \\ 54.9 & 190,000 \\ 54.7 & 180,000 \\ 56.5 & 220,000 \\ 54.1 & 195,000 \\ 54.3 & 210,000\end{array}$

The stage for the 1815 flood has been estimated from the height of the flood plain, from the stage and discharge at The Dalles, and by comparison with the stages of the 1856 and 1909 floods.

The stages of floods from 1815 to 1869 , except that of 1856 , are unknown. However, they were all of a lower crest stage than the flood of 1856. It is fairly certain, also, that the stages of any floods between 1856 and 1869 were lower than that of the 1909 flood.

There were no floods from 1869 to 1895 as great as those in 1896 and 1906 according to statements of the early settlers.

The stage for the 1897 flood was determined from its relation to the 1896 flood about one quarter of a mile upstream.

The discharges for all floods except those in 1909, 1917, and 1921 are, to a large extent, based on comparative stages and discharges at other points.

\section{INDIAN LEGEND FLOOD OF ABOUT 1815}

Reflector Bar (Diablo Dam). - The stories which were told by the Indians support the evidence that the highest flood marks not associated with a more recent flood, and still visible when J. E. Stewart made his investigations over a hundred years later, were left by a flood that occurred "about 1815." Mr. Frank Davis found where sand had been deposited on the ground in a gulch near the present Diablo Dam at an elevation of 22 feet about the datum of the former gaging station at Reflector Bar. It was assumed from the nature of the deposit that the sediment had been left by the stream during a high flood. On the south side of Canyon Diablo opposite the gulch, J. E. Stewart found a dim mark on the canyon wall at an elevation of 21.3 feet that marked the height to which some flood had washed the rock clean. He also found deposits of flood sand in crevices of the rock wall at the mouth of Canyon Diablo as high as 20.8 feet, Reflector Bar gage datum, and a small piece of bark apparently left by a flood in a rock crevice nearly as high. A deposit of sand and gravel was 
found on the right bank at the upper end of Reflector Bar that probably had been left by the river during a flood. This deposit was of clean material devoid of leaves, dirt, logs, and humus when viewed by Stewart in 1918. The cleanness was considered an indication that the deposit was not much more than 100 years old. An excavation was made on the bar near the ranger station quite a long distance from the point where the river would overflow the bank. Alternate layers of sand and charcoal were revealed which showed that floods large enough to deposit sand on the bar that far back from the river had occurred several times previously. The charcoal found between the layers of sand probably was produced by forest fires.

The deposit of fresh sand was very coarse, almost small gravel, and extended about 600 feet back from the bank. For a flood to carry the sand that far, it would have had to overtop the bank by a least a foot. An estimation that the flood overtopped the bank by 1.5 feet gives a gage height of 19.5 feet. A gage height of about 20 feet for the flood was obtained by averaging the flood evidence at Reflector Bar and by taking the slope of the water surface into consideration.

Rockport.-The magnitude of the 1815 flood is supported further by a legend among the Indians at Rockport that a number of their tribe were drowned on the bench where the Cuthbert ranch is located, during a great flood that occurred at night. This bench is at least 15 feet above the floodmark of 1917.

Concrete.-At The Dalles, L. J. Wright, Assistant County Engineer of Skagit County, found deposits of flood sand on the ground in the small northside gulch which lies back of an old cabin at the head of the canyon. This deposit corresponds to a gage height of 69.3 feet present datum.

Sedro Woolley.-Stewart estimated that this flood probably exceeded the flood of 1909 by about 7 feet and covered the highest ground in the town of Sedro Woolley with 1.5 feet of water. This would be equivalent to 10 feet of water in the present business district. Also, a stage of 63.5 feet (gage datum) is indicated for the 1815 flood.

\section{TREE-STAINTNG FLOOD OF ABOUT 1856}

During his investigations in 1918, Stewart found that the marks of the 1856 flood were so easily and frequently found that its crest could be traced throughout the valley more easily than those of the floods of 1896,1897 , and 1906 . In most places it was marked only by sand in the deep crevices of the bark of old cedar trees. There was no mud in the bark of the fir trees, because of the rapid rate at which they shed their bark. The stains formerly in the bark of the cedar trees had apparently faded by weathering or had been dissipated by the growth of the trees. 
Reflector Bar.-In 1923 near Reflector Bar, Stewart observed a deposit of fresh flood sand, 3.5 feet above the crest of the flood of 1909, that he believed indicated the crest of the flood of 1856. On that basis it was estimated that the flood reached a stage of 18.5 feet at the gage.

Concrete.- On the north rock wall close to the mount of The Dalles near Concrete a distinct high-water line at a gage height of 57.3 feet (present datum) was visible in 1923.

Birdsview.-Charles Presentine settled on his ranch above Birdsview in 1876. He found the ground surface, where his buildings now stand, underlain by very fresh-looking leaves and grass. The leaves and grass had been covered by sediment deposited by a flood that covered the flat to an unknown depth. The flat has not been overflowed since.

Mr. Kemmerick, an early settler, noted fresh flood sand inside hollow logs at his ranch below Birdsview. The logs were above any later floods. The fact that the logs were old and hollow when the sand was was deposited showed the flood to be recent; otherwise, the logs probably would have rotted away before Mr. Kemmerick saw them.

Sedro Woolley.-In 1897 the stain marks of 1856 still could be found on the trees with little difficulty. The crest heights of the floods of 1896 and 1897 were within 0.1 foot of each other. After one of those floods Mr. Hart ${ }^{2}$ measured up from the high-water mark to the tree stains and found the distance to be exactly 4.0 feet. Mr. E. J. Woods, a former gage reader at the Northern Pacific Railway bridge, saw only one tree after the flood of 1909 with the crest mark of the old flood on it, and that was 3.5 feet higher than the 1909 floodmark. Later that tree was burned, but in January 1918 Stewart found an old cedar tree in which mud from the tree-staining flood was found in the bark 3.5 feet above the 1909 floodmark. Both the latter trees were about two miles downstream from the Hart ranch at Sedro Woolley. As the gage height of the 1909 flood is 56.5 feet, the gage height of the 1856 flood would be about 60 feet.

\section{FLOODS OF 1880, 1882, AND 1894}

The summer floods of 1880,1882 , and 1894 are remembered for the long periods during which the bottom lands around Mount Vernon were inundated.

\section{FLOOD OF NOVEMBER 1897}

This flood was the highest since the valley was settled in 1878 . The river rose with remarkable suddenness, because a very warm chinook was accompanied by heavy rains. The Cascade, Sauk, and Baker Rivers were unusually high, which caused a high peak in the Skagit

- See footnote p. 20.

$577864-61-3$ 
River near the mouth of each stream. The chinook stopped suddenly after 36 hours; and, as a result, the peaks were rapidly reduced by channel storage as they passed down the Skagit River.

Reflector Bar.-At Reflector Bar this flood was of about the same magnitude as that of 1917. Both floods put about one foot of water over the floor of an old cabin on the Davis ranch 1.5 miles below Reflector Bar.

Marblemount.-Below Cascade River at Marblemount the flood of 1897 was 1.3 and 2.2 feet higher than the floods of 1909 and 1917, respectively, as measured between high-water marks made by residents at Marblemount during each flood. The difference was caused by an enormous flood in Cascade River in 1897.

Rockport.-The flood of 1897 is the highest ever observed by white men; however the amount by which it exceeded the floods of 1909 and 1917 is unknown.

Concrete.-Stewart found two floodmarks near Concrete for the flood of 1897. One, on a barn on the right bank about a mile upstream from Concrete, was transferred by levels to the footing of a hotel in Concrete on which the other floodmark had been made in 1909. The difference between the two marks was 5 feet. After allowing 2 feet for the slope of the water surface, the flood of 1897 was estimated to be 3 feet higher than the flood of 1909 . Later, in 1922, Stewart ran levels to a stump that a Mr. Magnus Miller stated was 1.5 feet out of water during the flood of 1897 . From these levels the flood of 1897 was found to be 3.6 feet higher than the flood of 1909 at Concrete.

The flood elevations in Concrete probably were affected to a considerable extent by the flow of Baker River. The relationship between the two floods at that point may have been quite different from the relationship at the gaging station site.

\section{FLOOD OF NOVEMBER 1909}

When Stewart made his investigations in 1918, the drift from the 1909 flood still lay along the river and was but slightly rotted. Drift for a previous higher flood could not be found; this indicated that none had occurred within the period required for drift to decay and disintegrate, perhaps 50 years.

Reflector Bar.-At Reflector Bar several distinct high-water marks were found by Stewart. One, on the front door of the Davis ranch house $1 \frac{11}{2}$ miles below the gage, was found to be 2.4 feet higher than the crest elevation obtained for the 1897 and 1917 floods at a nearby cabin. This stage was confirmed by the high-water mud lines still visible in 1918 on the rock wall of Canyon Diablo 700 feet above the gage and by the height of a drift log 100 feet below the gage. 
Newhalem.-The observer at the gaging station at Newhalem (near Marblemount) estimated the crest gage height the following morning from drift at the gage. This stage was checked in 1918 by Stewart using a hand level.

Concrete.-In 1918 Stewart found many marks of the flood of 1909 in and near Concrete. The footing of a hotel near the cement plant was just reached by the water. There were oil marks 4.5 feet above the floor on the outside galvanized siding of an old Washington Cement Plant shop building; these marks were referred to as being "as plain as though made yesterday."

\section{FLOOD OF DECEMBER 1917}

The flood of December 1917 was remarkable for the length of time it remained high, rather than for the height which it reached.

The gaging station at Reflector Bar was in operation; therefore, a good record of the flood was obtained at that point. As shown in the description of the flood of 1909 , the crest was 2.5 feet below that of 1909 .

\section{FLOOD OF DECEMBER 1921}

Gaging stations were in operation below Ruby Creek, at Reflector Bar, at Newhalem, and near Sedro Woolley at the time of the 1921 flood. Gage heights for the flood at those places are part of the gaging-station records.

Concrete.-Stewart made extensive studies of this flood at The Dalles near Concrete. He visited the place while the floodmarks still were so clear that the profile of the flood could be determined within one or two tenths of a foot. At The Dalles the Skagit River flows through a relatively narrow canyon for a short distance. Conditions there are fairly satisfactory for the computation of the peak flow by the contracted-opening method. Just below The Dalles is a straight reach of channel which is suitable for the computation of flow by the slope-area method. Stewart obtained the data for both types of measurements; the upper end of the rating curve for this gaging station is based on those computations.

\section{FLOOD OF FEBRUARY 1932}

The flood of February 1932 would probably have been much more serious if there had been no upstream storage. The storage probably reduced the peak by about 35,000 cfs at the gaging station near Concrete. In the lower reaches of the river, between Sedro Woolley and Mount Vernon, the dikes failed in two places and caused flooding of farm land and many homes. Also, several dike failures occurred along the distributaries near the mouth. 
Two gages were in operation along the main stem during this flood and good records were obtained at these points. The gages were located at Newhalem and at The Dalles near Concrete. The crest at Newhalem, which was affected to some extent by storage, was only 1.4 feet below that of the 1921 flood. The crest at the gage near Concrete has been listed as being 5.7 feet lower than that of the 1917 flood, but again upstream storage was a factor.

\section{FLOOD OF NOVEMBER 1949}

The flood of November 1949 would probably have been among those causing considerable damage if there had been no upstream storage. The storage in the power reservoirs has been estimated to have reduced the crest at the gaging station near Concrete by about $45,000 \mathrm{cfs}$. The peak near Concrete was of short duration, and there was only a moderate amount of inflow between Concrete and Mount Vernon. Channel storage reduced the peak in the lower reaches of the channel to a point where the diked channel was able to carry the peak flow without danger of a major dike failure. There were two minor breaks near the mouth.

Several gages were in operation along the main stem during this flood so good records were obtained at those points. Gages were in operation at Newhalem, at Marblemount, near Concrete, and near Mount Vernon. The crest near Concrete was 4.9 feet lower than that of the 1917 flood and 0.8 foot higher than the crest of the 1932 flood.

Immediately following the 1949 flood, a slope-area reach was laid out and high-water and other field data obtained at the approximate site of J. E. Stewart's reach just below The Dalles near Concrete. These data were used to verify the value of the channel roughness coefficient, $n$, at this site for use in estimating the validity of the results obtained by Stewart.

\section{FLOOD OF FEBRUARY 1951}

The flood of February 1951 was almost as high as the flood of 1949 at the gage near Concrete and was higher at the gage near Mount Vernon. The effect of upstream storage was much less for this flood than for some of the others and has been estimated to be about 13,000 cfs for the peak at the gage near Concrete. However, this peak was of quite long duration and a large amount of inflow occurred between Concrete and Mount Vernon so that channel storage had very little effect in reducing the peak stage in the lower reaches of the channel. In at least two places between Sedro Woolley and Mount Vernon the river reached the top of the dike. In one place the dike sprung a 
leak, but this dike did not fail, and as a result there was only minor damage in that area. However, several dike failures occurred on the distributaries near the mouth, and considerable areas of land and many homes were inundated.

Several gages were in operation along the main stem of the river during this flood so good records were obtained at those points. Gages were in operation at Newhalem, above Alma Creek near Marblemount, at Marblemount, near Concrete, near Sedro Woolley (unpublished), and near Mount Vernon.

\section{FLOOD RECORDS}

Records of maximum flood stages and discharges that have been obtained at gaging stations operated in the Skagit River basin for five or more years are presented in the following tables. They are of two kinds: records of historic floods, based largely on the investigations of J. E. Stewart; and records obtained during the period of operation of the gaging stations, when continuous records were obtained.

The order of listing gaging-station records begins with the most upstream main-stem station, near Hope, British Columbia, and proceeds downstream along the main stem. All stations on a tributary entering above a main-stem station are listed before that station, and if a tributary enters between two main-stem stations, it is listed between them. The gaging stations are numbered in the above order and may be located by number on plate 1 .

\section{GAGING STATION RECORDS}

The information on the following pages for each gaging station for which records are shown consists of a station description and a list of flood peaks.

The station description gives information as to location, drainage area, type of gage and elevation of gage datum, how well the stagedischarge relation is defined, remarks concerning effects of diversion and regulation, and other pertinent information.

Flood peaks listed for periods of gaging station operation are the maximum momentary peaks that occurred each water year, the year beginning October 1 and ending September 30. Also listed are stages and discharges for historical floods, including all those that occurred prior to time of beginning of systematic collection of data. A horizontal line across the year column indicates a break in the period of record and one across the gage height columr indicates a change in datum. 


\section{Skagit River near Hope, British Columbia, International gaging station}

Location.-Lat $49^{\circ} 02^{\prime} 50^{\prime \prime}$, long $121^{\circ} 05^{\prime} 45^{\prime \prime}$, on left bank just downstream from

Galena Creek, 4 miles upstream from the international boundary, and 27

miles southeast of Hope, British Columbia.

Drainage area.-357 sq mi.

Gage.-Water-stage recorder. Altitude of gage is $1,670 \mathrm{ft}$ (from topographic

map). Prior to October 1934, water-stage recorder at site $550 \mathrm{ft}$ downstream at different datum.

Stage-discharge relation.-Defined by current-meter measurements below 6,500 $\mathrm{cfs}$. Remarks.-Records furnished by Canadian Department of Resources and Development.

Annual peak stages and discharges of Skagit River near Hope, British Columbia

\begin{tabular}{|c|c|c|c|}
\hline Water year & Date & $\begin{array}{l}\text { Gage height } \\
\text { (feet) }\end{array}$ & $\begin{array}{l}\text { Discharge } \\
\text { (cfs) }\end{array}$ \\
\hline $\begin{array}{l}1915 \\
1916 \\
1917 \\
1918 \\
1919\end{array}$ & $\begin{array}{l}\text { Apr. 4, 1915 } \\
\text { June 17, } 1916 \\
\text { May 29, } 1917 \\
\text { June } 10,1918 \\
\text { May 26, } 1919\end{array}$ & 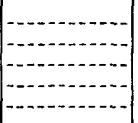 & $\begin{array}{l}11,280 \\
17,560 \\
15,920 \\
15,980 \\
15,140\end{array}$ \\
\hline 1921.1922 & $\begin{array}{l}\text { June } 7,1921 \\
\text { June 4, } 1922\end{array}$ & & $\begin{array}{l}16,920 \\
16,850\end{array}$ \\
\hline 1935 & $\begin{array}{l}\text { Jan. } 25,1935 \\
\text { May } 31,1936 \\
\text { June } 3,1937 \\
\text { May } 26,1938 \\
\text { May } 16,1939 \\
\text { May } 24,1940 \\
\text { May } 26,1941 \\
\text { May } 27,1943 \\
\text { May } 29,1944 \\
\text { May } 30,1945 \\
\text { May } 27,1946 \\
\text { May } 8,1947 \\
\text { May } 28,1948 \\
\text { May } 16,1949 \\
\text { May } 21,1950 \\
\text { May } 19,1951 \\
\text { June } 13,1952 \\
\text { May } 19,1954 \\
\text { June } 12,1955\end{array}$ & $\begin{array}{r}8.83 \\
7.90 \\
8.84 \\
8.71 \\
8.17 \\
6.52 \\
5.15 \\
7.49 \\
8.12 \\
6.46 \\
8.60 \\
8.85 \\
8.47 \\
10.75 \\
10.20 \\
12.20 \\
10.49 \\
10.21 \\
10.58 \\
11.95 \\
11.96\end{array}$ & $\begin{array}{r}6,560 \\
5,070 \\
6,570 \\
6,370 \\
5,440 \\
2,990 \\
1,560 \\
4,440 \\
5,420 \\
2,510 \\
5,560 \\
5,960 \\
5,630 \\
9,720 \\
6,850 \\
10,200 \\
5,560 \\
4,970 \\
5,720 \\
6,820 \\
9,760\end{array}$ \\
\hline
\end{tabular}

1 Maximum daily.

\section{Skagit River above Devils Creek, near Newhalem, Wash.}

Location.-Lat. $48^{\circ} 50^{\prime} 30^{\prime \prime}$, long $121^{\circ} 02^{\prime} 20^{\prime \prime}$, in W1/2 sec. 30 , T. 39 N., R. 14 E., on left bank 2 miles upstream from Devils Creek, $9 \frac{1}{2}$ miles upstream from Ross Dam, and 15 miles northeast of Newhalem.

Drainage area.-650 sq mi, approximately, of which $400 \mathrm{sq} \mathrm{mi}$ is in Canada. Gage.-Water-stage recorder. Altitude of gage is $1,410 \mathrm{ft}$ (from river-profile map).

Stage-discharge relation.-Defined by current-meter measurements below $6,600 \mathrm{cfs}$ and extended by logarithmic plotting. 
Annual peak stages and discharges of Skagit River above Devils Creek, near Newhalem, Wash.

\begin{tabular}{|c|c|c|c|}
\hline Water year & Date & $\underset{\text { (feet) }}{\text { Gage height }}$ & $\begin{array}{c}\text { Discharge } \\
\text { (cfs) }\end{array}$ \\
\hline 1940 & $\begin{array}{l}\text { May 24, } 1940 \\
\text { Oct. 21, } 1940 \\
\text { Dec. } 3,1941 \\
\text { June } 10,1943 \\
\text { May 16, } 1944 \\
\text { May 31, } 1945 .\end{array}$ & $\begin{array}{l}5.55 \\
4.58 \\
6.20 \\
6.80 \\
4.84 \\
7.27\end{array}$ & $\begin{array}{l}5,900 \\
4,210 \\
6,570 \\
8,220 \\
4,630 \\
9,140\end{array}$ \\
\hline
\end{tabular}

\section{Beaver Creek near Newhalem, Wash.}

Location.-Lat $48^{\circ} 46^{\prime} 40^{\prime \prime}$, long $121^{\circ} 04^{\prime} 20^{\prime \prime}$, in S $y_{2}$ sec. 14, T. 38 N., R. 13 E. (unsurveyed), on left bank three-quarters of a mile upstream from Ross Reservoir, 3 miles north of Ross Dam on Sakgit River, and 101/2 miles northeast of Newhalem.

Drainage area.- $52 \mathrm{sq} \mathrm{mi}$, approximately.

Gage.-Water-stage recorder. Altitude of gage is $1,600 \mathrm{ft}$ (from river-profile map).

Stage-discharge relation.-Defined by current-meter measurements below $2,000 \mathrm{cfs}$ and extended by logarithmic plotting.

Annual peak stages and discharges of Beaver Creek near Newhalem, Wash.

\begin{tabular}{|c|c|c|c|}
\hline Water year & Date & $\begin{array}{c}\text { Gage height } \\
\text { (feet) }\end{array}$ & $\begin{array}{l}\text { Discharge } \\
\text { (cfs) }\end{array}$ \\
\hline 1940 & $\begin{array}{l}\text { May } 24,1940 \\
\text { Oct. } 19,1940 \\
\text { Dec. } 2,1941 \\
\text { July } 4,1943 \\
\text { Dec. 3, } 1943 . \\
\text { May } 31,1945 \\
\text { Oct. 26, } 1945 \\
\text { Oct. 25, } 1946 \\
\text { May } 28,1948\end{array}$ & $\begin{array}{l}4.97 \\
7.34 \\
\text { 7.76 } \\
\text { 5. } 11 \\
\text { 4. } 63 \\
\mathbf{5 . 3 2} \\
\text { 7. } 57 \\
\text { 5. } 33 \\
\mathbf{6 . 3 7}\end{array}$ & $\begin{array}{l}1,320 \\
3,540 \\
3,980 \\
1,550 \\
1,280 \\
1,680 \\
3,760 \\
1,760 \\
2,490\end{array}$ \\
\hline
\end{tabular}

\section{Skagit River near Newhalem, Wash.}

[Published as "above Ruby Creek, near Marblemount" 1930-31]

Location.-Lat $48^{\circ} 44^{\prime} 50^{\prime \prime}$, long $121^{\circ} 01^{\prime} 50^{\prime \prime}$, in $\mathrm{S} 1 / 2$ sec. 30 , T. 38 N., R. 14 E. (unsurveyed), on right bank 1/4 miles upstream from Ruby Creek and 11 miles northeast of Newhalem.

Drainage area. $-765 \mathrm{sq} \mathrm{mi}$, of which $400 \mathrm{sq} \mathrm{mi}$ is in Canada.

Gage.-Water-stage recorder. Altitude of gage is $1,250 \mathrm{ft}$ (from river-profile map).

Stage-discharge relation.-Defined by current-meter measurements below 13,000 cfs and extended by velocity-area studies. 
Annual peak stages and discharges of Skagit River near Newhalem, Wash.

\begin{tabular}{|c|c|c|c|}
\hline Water year & Date & $\underset{\text { (foet) }}{\text { Gage height }}$ & $\underset{\text { (cfs) }}{\text { Discharge }}$ \\
\hline $1922 \ldots$ & Dec. $12,1921 \ldots$ & 17.8 & 33,000 \\
\hline $\begin{array}{l}1930 \\
1931 \\
1933 \\
1935 \\
1936\end{array}$ & \begin{tabular}{|l} 
June 11, 1930 \\
May 2, 1931 \\
Feb. 27,1932 \\
June 16, 1933 \\
Apr. 24,1934 \\
Nov. 5, 1934 \\
May 31, 1936 \\
June 3, 1937 \\
May 26, 1938 \\
May 29, 1939
\end{tabular} & \begin{tabular}{l|}
9.5 \\
10.2 \\
15.9 \\
13.1 \\
12.0 \\
13.05 \\
11.11 \\
11.39 \\
11.74 \\
11.13
\end{tabular} & $\begin{array}{r}8,270 \\
9,860 \\
25,700 \\
17,300 \\
14,300 \\
17,000 \\
12,000 \\
12,700 \\
13,600 \\
12,100\end{array}$ \\
\hline
\end{tabular}

\section{Ruby Creek below Panther Creek, near Newhalem, Wash.}

[Published as "Ruby Creek near Marblemount" prior to 1932 and as "Ruby Oreek near Newhalem" $1932-49]$

Location.-Lat $48^{\circ} 42^{\prime} 30^{\prime \prime}$, long $120^{\circ} 58^{\prime} 10^{\prime \prime}$, in NW 1/4 sec. 10, T. 37 N., R. $14 \mathrm{E}$. (unsurveyed), on right bank $200 \mathrm{ft}$ downstream from Panther Creek, 4 miles upstream from mouth, and 13 miles northeast of Newhalem.

Drainage area.-199 sq mi. At sites prior to October 1948, $210 \mathrm{sq} \mathrm{mi}$, approximately.

Gage.-Water-stage recorder. Altitude of gage is $1,640 \mathrm{ft}$ (by barometer). Prior to Mar. 8, 1940, water-stage recorder at site $3 \frac{1}{2}$ miles downstream and Mar. 8,1940 , to Sept. 27,1948 at site 2 miles downstream from present site, both at different datums.

Stage-discharge relation.-Defined by current meter measurements below 5,600 cfs and extended by logarithmic plotting.

Annual peak stages and discharges of Ruby Creek below Panther Creek, near Newhalem, Wash.

\begin{tabular}{|c|c|c|c|}
\hline Water year & Date & $\underset{\text { (feet) }}{\text { Gage height }}$ & $\begin{array}{l}\text { Discharge } \\
\text { (cfs) }\end{array}$ \\
\hline 1939 & $\begin{array}{l}\text { May 22, } 1929 \\
\text { June 6, } 1930 \\
\text { May 14, } 1931, \\
\text { Fob. 27, } 1932 \\
\text { June } 14,1933 \\
\text { Apr. 23, } 1934 \\
\text { Nov. 5, } 1934 \\
\text { June } 2,1936 \\
\text { June } 2,1937 \\
\text { May } 25,1938 \\
\text { May } 28,1939\end{array}$ & $\begin{array}{l}12.57 \\
12.10 \\
12.47 \\
14.15 \\
14.09 \\
13.74 \\
13.92 \\
13.51 \\
13.12 \\
13.08\end{array}$ & $\begin{array}{l}3,460 \\
3,030 \\
3,570 \\
6,730 \\
6,510 \\
4,920 \\
3,460 \\
4,850 \\
4,480 \\
4,530 \\
4,650\end{array}$ \\
\hline 1940 & $\begin{array}{l}\text { May } 23,1940 \\
\text { Oct. } 20,1940 \\
\text { May } 25,1942 \\
\text { June } 0,1943 \\
\text { May } 15,1944 \\
\text { May } 30,1945 \\
\text { May } 26,27,1946 \\
\text { May } 8,1947 \\
\text { May } 27,1948\end{array}$ & $\begin{array}{l}6.91 \\
5.88 \\
7.69 \\
7.45 \\
6.41 \\
7.56 \\
7.43 \\
7.50 \\
9.2\end{array}$ & $\begin{array}{l}3,070 \\
1,630 \\
4,650 \\
4,160 \\
2,370 \\
4,360 \\
4,160 \\
4,260 \\
9,920\end{array}$ \\
\hline $\begin{array}{l}1949 \\
1950 \\
1952 \\
1954 \\
1956\end{array}$ & $\begin{array}{l}\text { May 15, } 1949 \\
\text { Nov. 29, } 1949 \ldots \\
\text { May 23, } 1951 . \\
\text { May 18, 1952 } \\
\text { June 13, } 1953 . \\
\text { July } 1,1954 \\
\text { July } 16,1955 \\
\text { Oct. 25, } 1955\end{array}$ & $\begin{array}{r}8.42 \\
10.95 \\
7.50 \\
6.38 \\
7.16 \\
7.82 \\
9.50 \\
9.25\end{array}$ & $\begin{array}{l}5,170 \\
8,640 \\
4,170 \\
3,150 \\
3,820 \\
4,630 \\
6,540 \\
6,240\end{array}$ \\
\hline
\end{tabular}


6. Skagit River below Ruby Creek, near Newhalem, Wash.

[Published as "near Marblemount"]

Location.-Lat $48^{\circ} 44^{\prime} 20^{\prime \prime}$, long $121^{\circ} 03^{\prime} 40^{\prime \prime}$, in SEY 4 sec. 35 , T. 38 N., R. 13 E., (unsurveyed), on right bank three-quarters of a mile downstream from Ruby Creek and 9 miles northeast of Newhalem.

Drainage area.-978 sq mi, of which $400 \mathrm{sq} \mathrm{mi}$ is in Canada.

Gage.-Water-stage recorder. Altitude of gage is $1,190 \mathrm{ft}$ (from river-profile map).

Stage-discharge relation.-Defined by current-meter measurements below 11,000 cfs and extended by reducing discharge at Reflector Bar by measured inflow.

Annual peak stages and discharges of Skagit River below Ruby Creek, near Newhalem, Wash.

\begin{tabular}{|c|c|c|c|}
\hline Water year & Date & ${ }_{\text {(feet) }}^{\text {Gage height }}$ & $\begin{array}{c}\text { Discharge } \\
\text { (cfs) }\end{array}$ \\
\hline $\begin{array}{l}1920 \\
1921 \\
1923 \\
1924 \\
1926 \\
1927 \\
1928\end{array}$ & 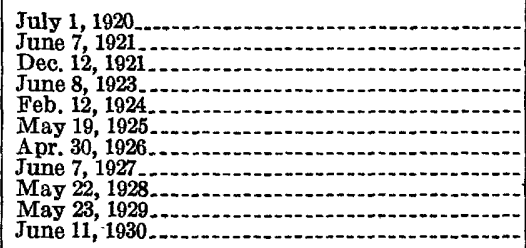 & $\begin{array}{c}9.39 \\
11.95 \\
16.1 \\
10.75 \\
12.2 \\
11.6 \\
7.76 \\
11.35 \\
11.4 \\
9.65 \\
8.9\end{array}$ & $\begin{array}{r}12,600 \\
25,200 \\
45,700 \\
19,200 \\
26,200 \\
23,200 \\
7,460 \\
22,200 \\
22,200 \\
13,600 \\
10,700\end{array}$ \\
\hline
\end{tabular}

7. Ross Reservoir near Newhalem, Wash.

[Published as "Ruby Reservoir" prior to 1945]

Location.-Lat $48^{\circ} 44^{\prime} 00^{\prime \prime}$, long $121^{\circ} 04^{\prime} 10^{\prime \prime}$, in SE $/ 4$ sec. 35, T. 38 N., R. 13 E., at Ross Dam on Skagit River, 1 mile downstream from Ruby Creek, and 9 miles northeast of Newhalem.

Drainage area. $-980 \mathrm{sq} \mathrm{mi,} \mathrm{approximately.}$

Gage.-Water-stage recorder. Datum of gage is at mean sea level (city of Seattle benchmark). Prior to Sept. 24, 1940, staff gage, and Sept. 24, 1940, to June 27, 1943, water-stage recorder at same site and datum. June 28, 1943, to Apr. 29, 1948, staff gage $500 \mathrm{ft}$ upstream at same datum.

Remarks.-Reservoir is formed by concrete arch dam completed to elevation $1,615 \mathrm{ft}$ in 1949; storage began Mar. 11, 1940. Capacity 1,202,920 acre-feet between elevations 1,250 ft (lowest outlet) and 1,582 ft (spillway crest).

Annual maximum elevation and storage of Ross Reservoir near Newhalem, Wash.

\begin{tabular}{|c|c|c|c|}
\hline Water year & Date & $\begin{array}{c}\text { Elevation } \\
\text { (feet, m.s.l.) }\end{array}$ & $\begin{array}{l}\text { Storage } \\
\text { (acre-feet) }\end{array}$ \\
\hline $\begin{array}{l}1941 \\
1942 \\
1944 \\
1945 \\
1946 \\
1948 \\
1949 \\
1950 \\
1952 \\
1954 \\
1955657\end{array}$ & $\begin{array}{l}\text { July } 19,1941 \\
\text { July } 23,1942 \\
\text { June } 30,1943 \\
\text { June } 11,1944 \\
\text { July } 31,1945 \\
\text { May } 27,1946 \\
\text { Aug. } 3,1947 \\
\text { July } 1,1948 \\
\text { Aug. } 5,1949 \\
\text { July } 10,1950 \\
\text { July } 27,1951 \\
\text { Aug. } 11,1952 \\
\text { Aug. 16, } 1953 \\
\text { Aug. } 23,1954 \\
\text { Aug. } 15,1955 \\
\text { Aug. } 1,1956 \\
\text { Aug. } 25,1957\end{array}$ & $\begin{array}{l}1,384.6 \\
1,384.7 \\
1,384.05 \\
1,381.8 \\
1,384.0 \\
1,415.85 \\
1,500.90 \\
1,562.52 \\
1,580.13 \\
1,582.88 \\
1,582.37 \\
1,582.06 \\
1,600.00 \\
1,600.10 \\
1,599.86 \\
1,600.00 \\
1,599.91\end{array}$ & $\begin{array}{r}112,600 \\
113,100 \\
111,800 \\
107,400 \\
111,700 \\
182,800 \\
514,490 \\
1,004,600 \\
1,184,000 \\
1,214,000 \\
1,208,000 \\
1,205,000 \\
1,405,300 \\
1,406,500 \\
1,404,100 \\
1,405,300 \\
1,404,100\end{array}$ \\
\hline
\end{tabular}




\section{Thunder Creek near Newhalem, Wash.}

[Published as "near Marblemount" prior to 1931 and as "above Colonial Creek, near Marblemount" in 1931]

Location.-Lat $48^{\circ} 40^{\prime} 20^{\prime \prime}$, long $121^{\circ} 04^{\prime} 20^{\prime \prime}$, in SE $1 / 4$ sec. 23, T. 37 N., R. 13 E. (unsurveyed), on right bank half a mile upstream from Diablo Reservoir, 8 miles east of Newhalem, and 20 miles northeast of Marblemount.

Drainage area. $-98 \mathrm{sq} \mathrm{mi}$, approximately. $111 \mathrm{sq} \mathrm{mi}$ at site prior to October 1930.

Gage.-Water-stage recorder. Altitude of gage is $1,220 \mathrm{ft}$ (from river-profile map). Prior to October 1930, water-stage recorder at site 3 miles downstream at different datum.

Stage-discharge relation.-Defined by current-meter measurements below 2,900 cfs and extended by logarithmic plotting.

Remarks.-Discharges for period 1920-30 at lower site were adjusted to upper site by 0.8 power of ratio of drainage areas.

Annual peak stages and discharges of Thunder Creek near Newhalem, Wash.

\begin{tabular}{|c|c|c|c|}
\hline Water jear & Date & $\underset{\text { (feet) }}{\text { Gage height }}$ & $\begin{array}{l}\text { Discharge } \\
\text { (cfs) }\end{array}$ \\
\hline 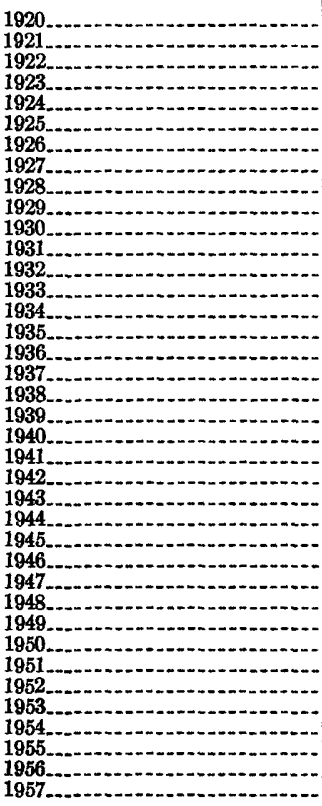 & $\begin{array}{l}\text { Sept. } 11,1920 \\
\text { June } 7,1921 \\
\text { Dec. } 12,1921 \\
\text { June } 9,1923 \\
\text { Feb. } 12,1924 \\
\text { Dec. } 12,1924 \\
\text { July } 5,1926 \\
\text { Oct. } 16,1926 \\
\text { May } 22,1928 \\
\text { Oct. } 9,1928 \\
\text { July } 13,1930 \\
\text { June } 26,1931 \\
\text { Feb. } 26,1932 \\
\text { Nov. } 13,1932 \\
\text { July } 16,1934 \\
\text { Nov. } 5,1934 \\
\text { May } 30,1936 \\
\text { June } 21,1937 \\
\text { Oct. } 28,1937 \\
\text { May } 28,1939 \\
\text { May } 23,1940 \\
\text { Oct. } 20,1940 \\
\text { Oct. } 3,1941 \\
\text { July } 10,1943 \\
\text { Sept. } 20,1944 \\
\text { Sept. } 4,1945 \\
\text { Oct. } 25,1945 \\
\text { Oct. } 25,1946 \\
\text { Oct. } 19,1947 \\
\text { May } 13,1949 \\
\text { Nov. } 27,1949 \\
\text { Feb. } 10,1951 \\
\text { June } 4,1952 \\
\text { Sept. } 28,1953 \\
\text { Aug. } 23,1954 \\
\text { July } 16,1955 \\
\text { Oct. } 25,1955 \\
\text { June } 11,1957 \\
\end{array}$ & $\left.\begin{array}{|r|} \\
\end{array}\right]$ & $\begin{array}{r}4,490 \\
4,140 \\
13,900 \\
2,880 \\
5,760 \\
3,800 \\
2,420 \\
9,410 \\
3,280 \\
7,960 \\
2,420 \\
3,630 \\
8,150 \\
5,010 \\
4,440 \\
6,120 \\
3,800 \\
2,650 \\
7,630 \\
4,740 \\
2,060 \\
5,430 \\
3,530 \\
2,300 \\
2,780 \\
3,080 \\
4,220 \\
5,550 \\
4,410 \\
2,560 \\
9,630 \\
3,870 \\
2,580 \\
2,690 \\
2,850 \\
3,170 \\
10,800 \\
2,790\end{array}$ \\
\hline
\end{tabular}




\section{Diablo Reservoir near Newhalem, Wash.}

Location.-Lat $48^{\circ} 43^{\prime} 00^{\prime \prime}$, long $121^{\circ} 08^{\prime} 00^{\prime \prime}$, in SE1/4 sec. 5, T. 37 N., R. 13 E. (unsurveyed), at Diablo Dam on Skagit River, 1 mile downstream from Thunder Creek, and 6 miles northeast of Newhalem.

Drainage area.-1,100 sq mi, approximately.

Gage.-Water-stage recorder. Datum of gage is at mean sea level, (City of Seattle bench mark). Prior to Oct. 12, 1931, staff gage at approximately same site and datum.

Remarks.-Reservoir is formed by concrete dam, completed in 1930; storage began in October 1929. Usable capacity, 76,220 acre-feet between elevations $1,040 \mathrm{ft}$ (bottom of outlet pipes) and 1,205 ft (top of taintor gates). Crest of spillway is at elevation 1,187 ft. Maximum contents prior to 1943 from capacity table dated Oct. 10, 1930; maximum content on July 14, 1933 from table used subsequent to 1943 is 90,600 acre-feet.

Annual maximum elevation and storage of Diablo Reservoir near Newhalem, Wash.

\begin{tabular}{|c|c|c|c|}
\hline Water year & Date & $\begin{array}{c}\text { Elevation } \\
\text { (feet, m.s.1.) }\end{array}$ & $\begin{array}{c}\text { Storage } \\
\text { (acre-feet) }\end{array}$ \\
\hline $\begin{array}{l}1932 \\
1933 \\
1935 \\
1938 \\
1939 \\
1940\end{array}$ & 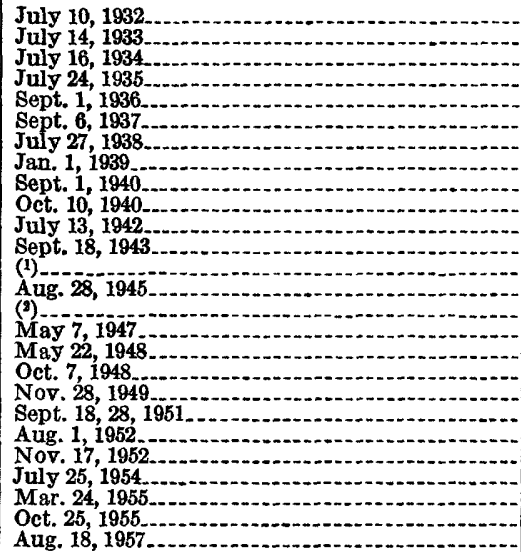 & $\begin{array}{l}1,205.76 \\
1,206.5 \\
1,206.02 \\
1,206.08 \\
1,206.20 \\
1,206.00 \\
1,206.30 \\
1,206.17 \\
1,206.16 \\
1,206.01 \\
1,206.2 \\
1,206.0 \\
1,205.1 \\
1,206.0 \\
1,206.0 \\
1,206.18 \\
1,206.1 \\
1,198.2 \\
1,205.0 \\
1,205.9 \\
1,205.6 \\
1,206.0 \\
1,205.89 \\
1,206.17 \\
1,205.85\end{array}$ & $\begin{array}{l}92,010 \\
92,720 \\
92,260 \\
92,230 \\
92, \mathbf{4 3 0} \\
92,240 \\
92, \mathbf{5 2 0} \\
92,400 \\
92,390 \\
92,340 \\
92,430 \\
90,050 \\
90,140 \\
89,310 \\
90,140 \\
90,140 \\
90,310 \\
90,230 \\
83,200 \\
89,220 \\
90,050 \\
89,770 \\
90,140 \\
90,040 \\
90,300 \\
90,000\end{array}$ \\
\hline
\end{tabular}

1 Oct. 2 and Dec. 14, 1943, Mar. 16, 27, July 26, and Aug. 3, 7, 24, 1944.

May 22 and June 14, 1946. 
10. Skagit River at Reflector Bar, near Newhalem, Wash.

[Published as "near Marblemount" 1913-22]

Location.-Lat $48^{\circ} 42^{\prime} 50^{\prime \prime}$, long $121^{\circ} 08^{\prime} 30^{\prime \prime}$, in N1/2 sec. 8, T. 37 N., R. 13 E. (unsurveyed), on right bank just downstream from Canyon Diablo, a quarter of a mile downstream from later site of Diablo Dam, three-quarters of a mile upstream from Stetattle Creek, 13/2 miles downstream from Thunder Creek, 6 miles northeast of Newhalem, and 19 miles northeast of Marblemount.

Drainage area.-1,100 sq mi, approximately, of which $400 \mathrm{sq} \mathrm{mi}$ is in Canada. Gage.-Water-stage recorder. Altitude of gage is $880 \mathrm{ft}$ (from river-profile map). Dec. 6, 1913 to Apr. 13, 1914, staff gage at same site and datum.

Stage-discharge relation.-Defined by current-meter measurements below 24,000 cfs and extended by logarithmic plotting.

Annual peak stages and discharges of Skagit River at Reflector Bar, near Newhalem, Wash.

\begin{tabular}{|c|c|c|c|}
\hline Water year & Date & $\begin{array}{c}\text { Gage height } \\
\text { (feet) }\end{array}$ & $\begin{array}{l}\text { Discharge } \\
\text { (cfs) }\end{array}$ \\
\hline 1815 & & 20.5 & 115,000 \\
\hline 1856 & & 18.5 & 95,000 \\
\hline 1898 & Nov. 18,1897 & 12.5 & 48,000 \\
\hline 1910 & Nov. 29,1909 & 15.4 & 70,000 \\
\hline 1918 & $\begin{array}{l}\text { Jan. 6, } 1914 \\
\text { Apr. } 3,1915 \\
\text { June } 17,1916, \\
\text { June } 16,1917 \\
\text { Dec. } 29,1917 \\
\text { May } 27,1919 \\
\text { July 1, 1920 } \\
\text { June } 7,1921 . \\
\text { Dec. } 12,1921\end{array}$ & $\begin{array}{r}7.8 \\
6.52 \\
10.5 \\
8.19 \\
12.0 \\
9.0 \\
7.0 \\
10.7 \\
14.1\end{array}$ & $\begin{array}{l}16,800 \\
11,800 \\
29,400 \\
19,700 \\
37,300 \\
24,200 \\
15,600 \\
30,800 \\
58,000\end{array}$ \\
\hline
\end{tabular}




\section{Stetattle Creek near Newhalem, Wash.}

[Published as "near Marblemount" 1913-15]

Location.-Lat $48^{\circ} 43^{\prime} 30^{\prime \prime}$, long $121^{\circ} 09^{\prime} 20^{\prime \prime}$, in NE1/4 sec. 6, T. 37 N., R. 13 E., on left bank three-quarters of a mile upstream from mouth, $5 \frac{1}{2} 2$ miles northeast of Newhalem, and 181/2 miles northeast of Marblemount.

Drainage area.-21.4 sq mi.

Gage.-Water-stage recorder Altitude of gage is $925 \mathrm{ft}$ (by barometer). Sept. 7, 1933, to Aug. 26, 1937, water-stage recorder $150 \mathrm{ft}$ upstream at datum $1.69 \mathrm{ft}$ higher.

Stage-discharge relation.-Defined by current-meter measurements below 1,500 cfs and extended on basis of slope-area determination of the Nov. 26, 1949 flood peak.

Annual peak stages and discharges of Stetattle Creek near Newhalem, Wash.

\begin{tabular}{|c|c|c|c|}
\hline Water year & Date & $\begin{array}{c}\text { Gage height } \\
\text { (feet) }\end{array}$ & $\begin{array}{c}\text { Discharge } \\
\text { (cfs) }\end{array}$ \\
\hline $1934 \ldots \ldots$ & $\begin{array}{l}\text { Oct. 23, } 1933 \\
\text { Nov. 5, 1934 } \\
\text { June 2, } 1936 \\
\text { June 18, } 1937\end{array}$ & $\begin{array}{c}7.17 \\
10.4 \\
4.78 \\
5.50\end{array}$ & $\begin{array}{l}\mathbf{2}, 020 \\
\mathbf{5}, 640 \\
1,010 \\
\mathbf{1}, 370\end{array}$ \\
\hline $\begin{array}{l}1938 \\
1939 \\
1941 \\
1942 \\
1943 \\
1948 \\
1949 \\
1950 \\
1951 \\
1952 \\
1954 \\
1955 \\
1956\end{array}$ & 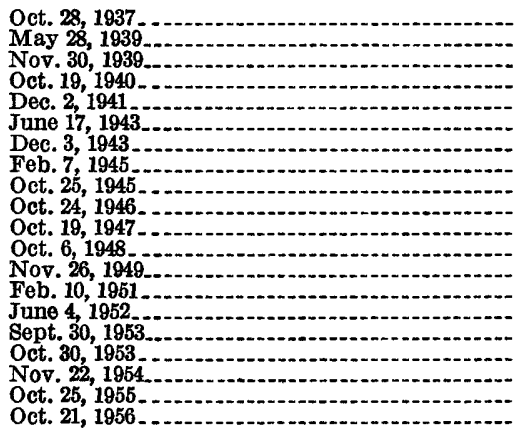 & $\begin{array}{l}7.34 \\
6.64 \\
5.10 \\
6.03 \\
6.77 \\
4.70 \\
5.62 \\
6.10 \\
7.16 \\
5.85 \\
6.80 \\
5.87 \\
9.70 \\
-4.76 \\
5.20 \\
5.08 \\
4.88 \\
7.34 \\
5.08\end{array}$ & $\begin{array}{r}3,220 \\
2,560 \\
1,130 \\
1,940 \\
2,680 \\
870 \\
1,510 \\
1,980 \\
3,210 \\
1,740 \\
2,730 \\
1,740 \\
\mathbf{8}, 580 \\
1,300 \\
1,480 \\
1,820 \\
1,710 \\
1,540 \\
4,330 \\
1,710\end{array}$ \\
\hline
\end{tabular}

1 Estimated. 


\section{Skagit River at Newhalem, Wash.}

[Published as "near Marblemount" 1909-14, 1921-31]

Location.-Lat $48^{\circ} 40^{\prime} 20^{\prime \prime}$, long $121^{\circ} 14^{\prime} 45^{\prime \prime}$, in SE1/4 sec. 21 , T. 37 N., R. 12 E., on right bank a quarter of a mile upstream from Newhalem Creek, half a mile downstream from city of Seattle powerplant at Newhalem, 11 miles upstream from Bacon Creek, and 13 miles northeast of Marblemount.

Drainage area.-1,160 sq mi, approximately, of which $400 \mathrm{sq} \mathrm{mi}$ is in Canada.

Gage.-Water-stage recorder. Datum of gage is $401.5 \mathrm{ft}$ above mean sea level (river-profile survey). Dec. 21, 1908, to May 23, 1914, staff gages half a mile upstream at datum $91 \mathrm{ft}$ higher, Nov. 15, 1920, to June 4, 1923, staff gage $500 \mathrm{ft}$ upstream at present datum.

Stage-discharge relation.-Defined by current-meter measurements below 26,500 cfs.

Remarks.-Flow partly regulated by Gorge Dam since August 1924, by Diablo Reservoir since October 1929, and by Ross Reservoir since March 1940.

Annual peak stages and discharges of Skagit River at Newhalem, Wash.

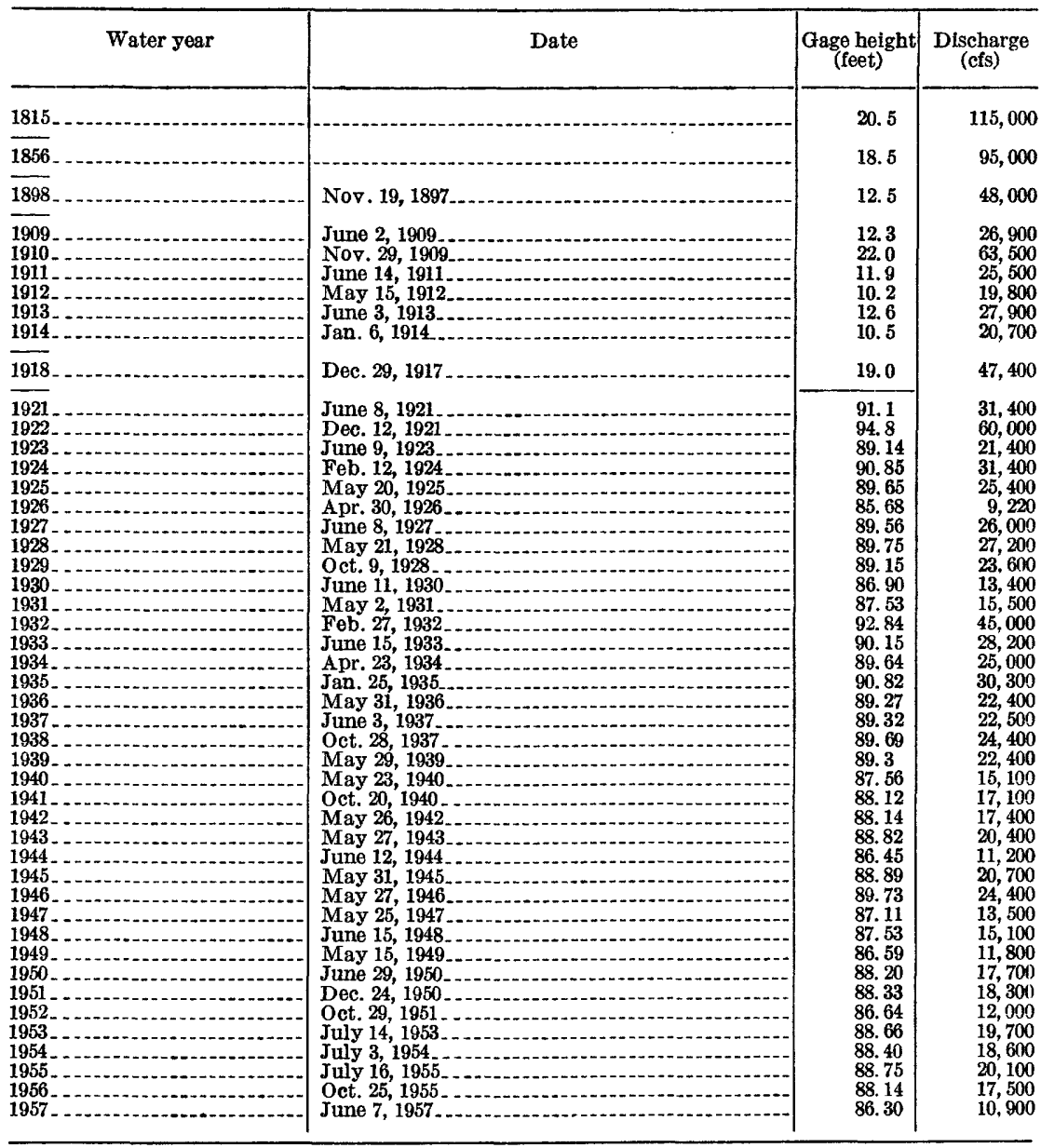


13. Skagit River above Alma Creek, near Marblemount, Wash.

Location.-Lat $48^{\circ} 36^{\prime} 25^{\prime \prime}$, long $121^{\circ} 21^{\prime} 35^{\prime \prime}$, in NE1/4 sec. 15 , T. 36 N., R. 11 E., on right bank three-quarters of a mile upstream from Alma Creek and 7 miles north of Marblemount.

Drainage area.-1,260 sq mi, approximately, of which $400 \mathrm{sq} \mathrm{mi}$ is in Canada.

Gage.-Water-stage recorder. Datum of gage is $358.8 \mathrm{ft}$ above mean sea level (from river-profile survey).

Stage-discharge relation.-Defined by current-meter measurements below 21,000 cfs and extended by logarithmic plotting.

Remarks.-Flow partly regulated by powerplants on upper Skagit River, and by Ross and Diablo Reservoirs.

Annual peak stages and discharges of Skagit River above Alma Creek, near Marblemount, Wash.

\begin{tabular}{|c|c|c|c|}
\hline Water year & Date & $\underset{\text { (feet) }}{\text { Gage height }}$ & $\begin{array}{c}\text { Discharge } \\
\text { (cfs) }\end{array}$ \\
\hline $\begin{array}{l}1951 \\
1952 \\
1954 \\
1956 \\
1957\end{array}$ & $\begin{array}{l}\text { Feb. 10, } 1951 \\
\text { Oct. } 29,1951 \\
\text { July 14, } 1953 \\
\text { July } 3,1954 \\
\text { July } 16,1955 \\
\text { Oct. } 25,1955 \\
\text { Oct. 17, } 1956\end{array}$ & $\begin{array}{l}14.40 \\
10.26 \\
12.44 \\
12.24 \\
13.44 \\
14.64 \\
11.37\end{array}$ & $\begin{array}{l}28,000 \\
12,900 \\
20,200 \\
19,400 \\
24,200 \\
29,400 \\
16,800\end{array}$ \\
\hline
\end{tabular}

14. Bacon Creek near Marblemount, Wash.

Location.-Lat $48^{\circ} 35^{\prime} 20^{\prime \prime}$, long $121^{\circ} 23^{\prime} 40^{\prime \prime}$, on line between secs. 20 and 21 , T. 36 N., R. 11 E., on highway bridge near right bank a quarter of a mile upstream from mouth and 41/2 miles north of Marblemount.

Drainage area.-50.9 sq mi.

Gage.-Wire-weight gage read twice daily. Gage heights are from graphs based on gage readings, except that for the 1950 water year, which is from a highwater mark. Altitude of gage is $350 \mathrm{ft}$ (from river-profile map).

Stage-discharge relation.-Defined by current-meter measurements below 2,000 cfs and extended on basis of slope-area determination of the Nov. 26, 1949 flood peak.

Annual peak stages and discharges of Bacon Creek near Marblemount, Wash.

\begin{tabular}{|c|c|c|c|}
\hline Water year & Date & $\underset{\text { (feet) }}{\text { Gage height }}$ & $\begin{array}{l}\text { Discharge } \\
\text { (cfs) }\end{array}$ \\
\hline 1944 & $\begin{array}{l}\text { Dec. } 3,1943 \\
\text { Feb. } 7,1945, \\
\text { Oct. } 25,1945, \\
\text { Oct. } 24,1946-19 \\
\text { Oct. } 19,1947 \\
\text { Oct. } 7,1948 \\
\text { Nov. } 26,1949\end{array}$ & $\begin{array}{l}4.25 \\
5.62 \\
6.20 \\
5.88 \\
5.67 \\
4.65 \\
7.13\end{array}$ & $\begin{array}{r}3,050 \\
5,510 \\
7,000 \\
6,480 \\
5,670 \\
3,300 \\
18,100\end{array}$ \\
\hline
\end{tabular}




\section{Skagit River at Marblemount, Wash.}

Location.-Lat $48^{\circ} 32^{\prime} 00^{\prime \prime}$, long $121^{\circ} 25^{\prime} 40^{\prime \prime}$, in NW1/4 sec. 7, T. 35 N., R. 11 E., on right bank half a mile north of Marblemount and 0.6 mile upstream from Cascade River.

Drainage area. $-1,360 \mathrm{sq} \mathrm{mi}$, approximately, of which $400 \mathrm{sq} \mathrm{mi}$ is in Canada.

Gage.-Water-stage recorder. Datum of gage is $305.1 \mathrm{ft}$ above mean sea level (river-profile survey).

Stage-discharge relation.-Defined by current-meter measurements below 20,000 cfs and extended by logarithmic plotting.

Remarks.-Flow partly regulated by powerplants on upper Skagit River, and by Diablo and Ross Reservoirs.

Annual peak stages and discharges of Skagit River at Marblemount, Wash.

\begin{tabular}{|c|c|c|c|}
\hline Water year & Date & $\underset{\text { (feet) }}{\text { Gage height }}$ & $\begin{array}{c}\text { Discharge } \\
\text { (cfs) }\end{array}$ \\
\hline 1944 & Dec. $3,1943 \ldots$ & 5. 66 & 16,800 \\
\hline $\begin{array}{l}1947 \\
1948 \\
1950 \\
1951 \\
1952 \\
1954\end{array}$ & 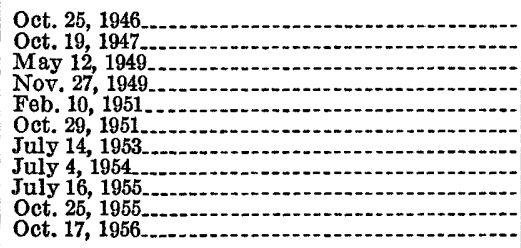 & \begin{tabular}{r|}
6.98 \\
8.52 \\
5.90 \\
11.37 \\
9.65 \\
5.40 \\
6.64 \\
6.69 \\
7.37 \\
9.25 \\
7.01
\end{tabular} & $\begin{array}{l}24,600 \\
35,400 \\
17,900 \\
59,300 \\
42,400 \\
14,000 \\
20,500 \\
21,100 \\
25,600 \\
38,900 \\
23,000\end{array}$ \\
\hline
\end{tabular}

16. Cascade River at Marblemount, Wash.

[Published as "near Marblemount" 1909-12]

Location.-Lat $48^{\circ} 31^{\prime} 25^{\prime \prime}$, long $121^{\circ} 23^{\prime} 00^{\prime}$, in N1/2 sec. 16, T. 35 N., R. 11 E., on right bank 11/2 miles downstream from Boulder Creek, 2 miles east of Marblemount, and 21/2 miles upstream from mouth.

Drainage area.-171 sq mi. $140 \mathrm{sq} \mathrm{mi,} \mathrm{approximately,} \mathrm{at} \mathrm{site} \mathrm{prior} \mathrm{to} \mathrm{May} 1,1913$. Gage.-Water-stage recorder. Datum of gage is $380.3 \mathrm{ft}$ above mean sea level (river-profile survey). April 1909 to May 1, 1913, staff gages at site 51/2 miles upstream from present site at different datums.

Stage-discharge relation.-Defined by current-meter measurements below 5,000 ofs and extended by logarithmic plotting.

Remarks.-Discharges for period 1909-12 at upper site were adjusted to lower site by 0.8 power of ratio of drainage areas. 
Annual peak stages and discharges of Cascade River at Marblemount, Wash.

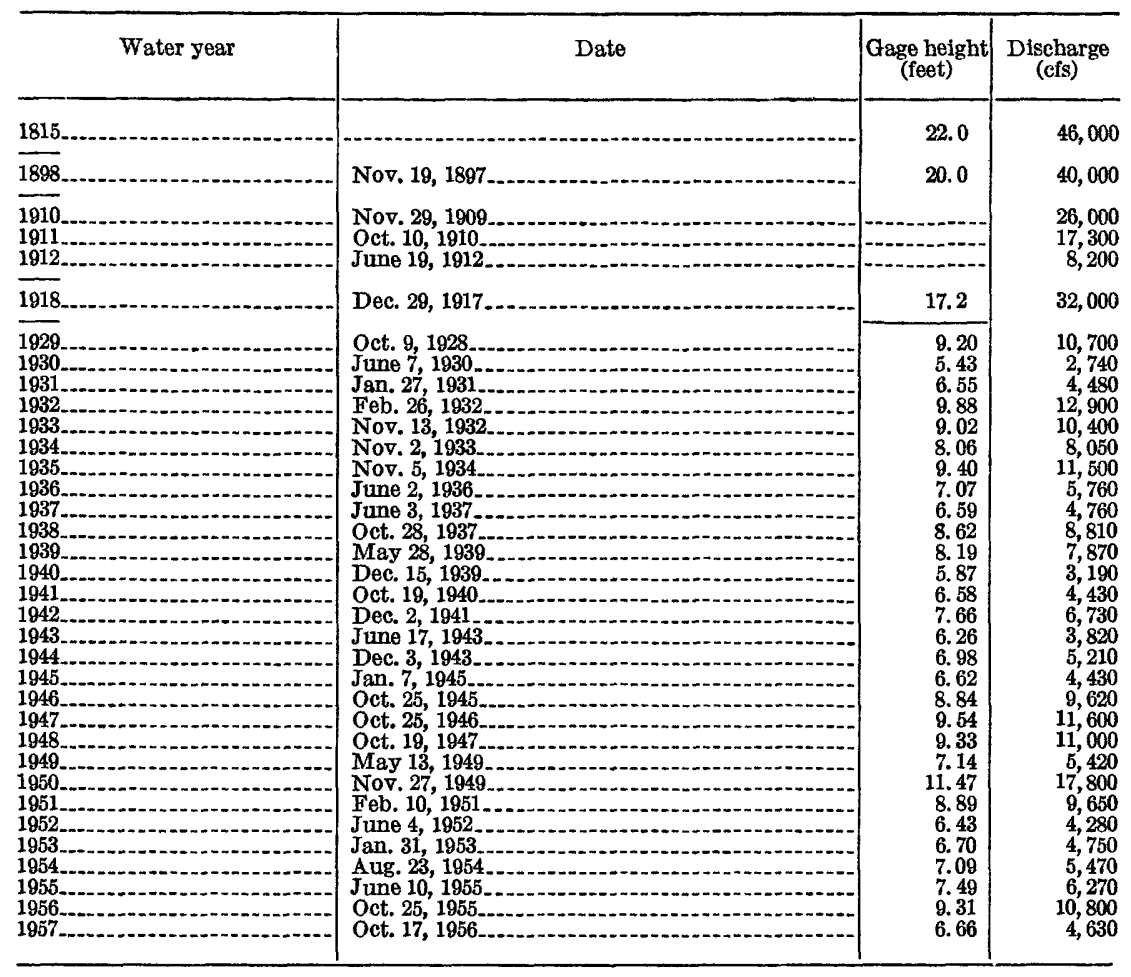

\section{South Fork Sauk River near Barlow Pass, Wash.}

Location.-Lat $48^{\circ} 03^{\prime} 45^{\prime \prime}$, long $121^{\circ} 24^{\prime} 20^{\prime \prime}$, in NE1/s sec. 29 , T. 30 N., R. 11 E. (unsurveyed), 23/4 miles upstream from North Fork, 31/2 miles northeast of Barlow Pass, and 16 miles southeast of Darrington.

Drainage area. $-32.7 \mathrm{sq} \mathrm{mi}$.

Gage.-Water-stage recorder. Altitude of gage is $1,550 \mathrm{ft}$ (from river-profile map).

Stage-discharge relation.-Defined by current-meter measurements below 1,400 cfs and extended by logarithmic plotting.

Annual peak stages and discharges of South Fork Sauk River near Barlow Pass, Wash.

\begin{tabular}{|c|c|c|c|}
\hline Water year & Date & $\underset{\text { (feet) }}{\text { Gage height }}$ & $\begin{array}{c}\text { Discharge } \\
\text { (cfs) }\end{array}$ \\
\hline 1918 & $\begin{array}{l}\text { Dec. } 29,1917 \ldots \\
\text { Dec. } 14,1918, \ldots \\
\text { Nov. } 15,1919\end{array}$ & $\begin{array}{l}9.1 \\
6.3 \\
7.7\end{array}$ & $\begin{array}{l}9,410 \\
3,350 \\
5,870\end{array}$ \\
\hline$\overline{1922 .}$ & Dec. 12,1921 & 9.5 & 10,500 \\
\hline $\begin{array}{l}1929 \\
1930 \\
1931\end{array}$ & $\begin{array}{l}\text { June 15, } 1929 \\
\text { Feb. 5, } 1930 \\
\text { Jan. 27, } 1931\end{array}$ & $\begin{array}{l}\mathbf{5 . 3 7} \\
\mathbf{6 . 3 7} \\
\mathbf{7 . 2 2}\end{array}$ & $\begin{array}{l}1,100 \\
2,080 \\
3,210\end{array}$ \\
\hline
\end{tabular}




\section{Sauk River above Whitechuck River, near Darrincton, Wash.}

Location.-Lat $48^{\circ} 10^{\prime} 00^{\prime \prime}$, long $121^{\circ} 27^{\prime} 45^{\prime \prime}$, in $\mathrm{NW}^{1 / 4}$ sec. 24, T. 31 N., R. 10 E., on right bank half a mile upstream from Whitechuck River and $9 \frac{1}{2}$ miles southeast of Darrington.

Drainage area.-152 sq mi.

Gage.-Water-stage recorder. Altitude of gage is $930 \mathrm{ft}$ (from river-profile map).

Stage-dischargc relation.-Defined by current-meter measurements below 6,200 cfs and extended by logarithmic plotting.

Remarks.-Discharge for 1951 estimated by correlation with record for Sauk River near Sauk, Wash.

Annual peak stages and discharges of Sauk River above Whitechuck River, near Darrington, Wash.

\begin{tabular}{|c|c|c|c|}
\hline Water year & Date & $\left|\begin{array}{c}\text { Gage height } \\
\text { (feet) }\end{array}\right|$ & $\begin{array}{l}\text { Discharge } \\
\text { (cfs) }\end{array}$ \\
\hline $\begin{array}{l}1918 \\
1919 \\
1920 \\
1921 \\
1922\end{array}$ & $\begin{array}{l}\text { Dec. } 29,1917 \\
\text { Dec. } 14,1918 \\
\text { Nov. } 15,1919 \\
\text { Oct. } 4,1920 \\
\text { Dec. } 12,1921\end{array}$ & $\begin{array}{r}13.3 \\
7.9 \\
9.0 \\
8.1 \\
14.65\end{array}$ & $\begin{array}{r}24,400 \\
8,430 \\
11,400 \\
8,960 \\
29,100\end{array}$ \\
\hline 1929 1930 & 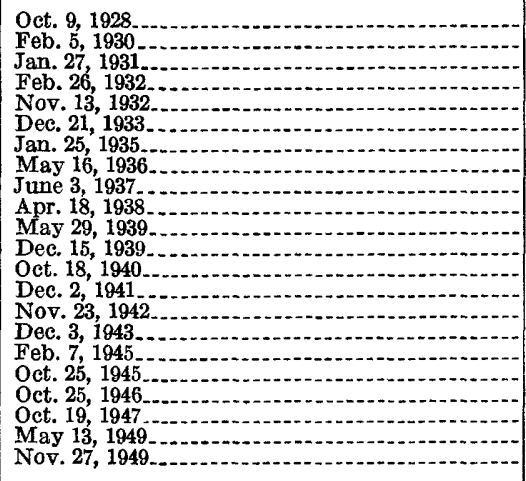 & $\begin{array}{r}7.50 \\
6.35 \\
7.72 \\
13.0 \\
10.3 \\
12.05 \\
10.41 \\
6.26 \\
6.19 \\
8.23 \\
7.60 \\
6.71 \\
5.94 \\
7.61 \\
7.06 \\
9.00 \\
8.40 \\
8.00 \\
8.50 \\
9.68 \\
6.52 \\
14.90\end{array}$ & $\begin{array}{r}7,030 \\
5,060 \\
7,410 \\
22,900 \\
13,000 \\
18,600 \\
13,200 \\
4,400 \\
4,310 \\
8,240 \\
7,010 \\
5,480 \\
4,180 \\
7,220 \\
6,230 \\
10,300 \\
8,940 \\
8,950 \\
10,200 \\
13,500 \\
5,660 \\
30,200 \\
20,800\end{array}$ \\
\hline 1950. & 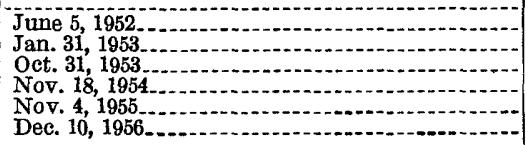 & $\begin{array}{l}6.41 \\
8.17 \\
6.56 \\
6.76 \\
9.86 \\
8.19\end{array}$ & $\begin{array}{r}20,800 \\
5,080 \\
9,360 \\
5,600 \\
5,990 \\
14,400 \\
9,650\end{array}$ \\
\hline
\end{tabular}

19. Sauk River at Darrington, Wash.

Location.-Lat $48^{\circ} 15^{\prime} 00^{\prime \prime}$, long $121^{\circ} 35^{\prime} 00^{\prime \prime}$, in SW1/4 sec. 24, T. 32 N., R. 9 E., on right bank half a mile southeast of Darrington and $21 / 4$ miles downstream from Clark Creek.

Drainage area. $-293 \mathrm{sq} \mathrm{mi}$.

Gage.-Staff gage read once or twice daily. Altitude of gage is $525 \mathrm{ft}$ (from riverprofile map). July 1914 to Apr. 14, 1922, staff gage $700 \mathrm{ft}$ upstream at different datum. Gage heights are from graphs based on gage readings.

Stage-discharge relation.-Defined by current-meter measurements below 7,700 efs and extended by velocity-area studies. 
Annual peak stages and discharges of Sauk River at Darrington, Wash.

\begin{tabular}{|c|c|c|c|}
\hline Water year & Date & $\begin{array}{c}\text { Gage height } \\
\text { (feet) }\end{array}$ & $\begin{array}{c}\text { Discharge } \\
\text { (cfs) }\end{array}$ \\
\hline 1815 & & 18.0 & 48,000 \\
\hline$\overline{1808}$ & Nov. 1897 & 17.0 & 44,000 \\
\hline 1010 & Nov, 29,1909 & 16.0 & 40,000 \\
\hline 1916 & $\begin{array}{l}\text { Apr. } 2,1915 \\
\text { Dec. } 8,1915 \\
\text { Nov. } 9,1916,19 \\
\text { Dec. } 29,1917 \\
\text { Dec. } 14,1918,19 \\
\text { Nov. } 15,1919 \\
\text { Oct. } 4,1920 \\
\text { Dec. } 12,1921 .\end{array}$ & $\begin{array}{r}8.8 \\
7.4 \\
6.2 \\
15.0 \\
9.7 \\
10.5 \\
10.1 \\
15.0\end{array}$ & $\begin{array}{r}16,500 \\
12,000 \\
8,260 \\
36,000 \\
15,100 \\
17,200 \\
16,200 \\
36,000\end{array}$ \\
\hline 1924.1925 & $\begin{array}{l}\text { Dec. } 24,1922 \\
\text { Feb. } 12,1924 \\
\text { Dec. } 11,1924 \\
\text { Jan. } 5,1926\end{array}$ & $\begin{array}{r}8.0 \\
12.1 \\
9.0 \\
7.5\end{array}$ & $\begin{array}{l}12,300 \\
27,200 \\
15,500 \\
10,800\end{array}$ \\
\hline 1929 & $\begin{array}{l}\text { Oct. 9, } 1928 \\
\text { Feb. 5, } 1930 \\
\text { Jan. 27-28, } 1931 . \\
\text { Feb. 26, } 1932 .\end{array}$ & \begin{tabular}{r|}
8.5 \\
7.1 \\
8.4 \\
16.0
\end{tabular} & $\begin{array}{r}13,900 \\
9,630 \\
13,600 \\
46,500\end{array}$ \\
\hline
\end{tabular}

20. Suiattle River near Mansford, Wash.

Location.-Lat $48^{\circ} 21^{\prime} 50^{\prime \prime}$, long $121^{\circ} 29^{\prime} 30^{\prime \prime}$, in N1/2 sec. 10, T. 33 N., R. 10 E., left bank 21/2 miles downstream from Big Creek and 4 miles north of Mansford. Drainage area. $-335 \mathrm{sq} \mathrm{mi}$.

Gage.-Water-stage recorder. Altitude of gage is $530 \mathrm{ft}$ (from river-profile map). Stage-discharge relation.-Defined by current-meter measurements below 15,000 cfs and extended by logarithmic plotting.

Annual peak stages and discharges of Suiattle River near Mansford, Wash.

\begin{tabular}{|c|c|c|c|}
\hline Water year & Date & $\begin{array}{c}\text { Gage height } \\
\text { (feet) }\end{array}$ & $\begin{array}{l}\text { Discharge } \\
\text { (cfs) }\end{array}$ \\
\hline 1940 & 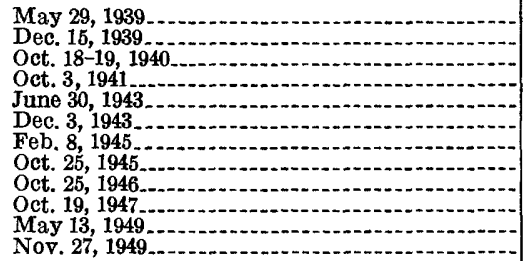 & $\begin{array}{r}9.79 \\
7.97 \\
7.83 \\
9.78 \\
8.82 \\
9.47 \\
9.70 \\
10.90 \\
12.86 \\
12.33 \\
9.89 \\
15.60\end{array}$ & $\begin{array}{r}9,680 \\
5,580 \\
4,980 \\
9,100 \\
7,200 \\
8,850 \\
9,520 \\
12,600 \\
19,200 \\
18,000 \\
9,900 \\
30,700\end{array}$ \\
\hline
\end{tabular}




\section{Sauk River near Sauk, Wash.}

Location.-Lat $48^{\circ} 25^{\prime} 15^{\prime \prime}$, long $121^{\circ} 34^{\prime} 00^{\prime \prime}$, in NW1/4 sec. 19 , T. 34 N., R. 10 E., on left bank 5 miles upstream from mouth, 5 miles southeast of Sauk, and 8 miles downstream from Suiattle River.

Drainage area. $-714 \mathrm{sq} \mathrm{mi}$.

Gage.-Water-stage recorder. Datum of gage is $266 \mathrm{ft}$ above mean sea level (river-profile survey).

Stage-discharge relation.-Defined by current-meter measurements below 40,000 efs and extended by logarithmic plotting.

Remarks.-Peak for 1912 from record obtained at several sites from 1 mile downstream to 5 miles upstream from present site during period 1910-12.

Annual peak stages and discharges of Sauk River near Sauk, Wash.

\begin{tabular}{|c|c|c|c|}
\hline Water year & Date & $\underset{\text { (fe日t) }}{\text { Gage height }}$ & $\begin{array}{c}\text { Discharge } \\
\text { (cis) }\end{array}$ \\
\hline 1912 & Nov, 19, 1911 & 8. 7 & 28,000 \\
\hline 929 & Oct. 9,1928 & 9.33 & 21,800 \\
\hline 1930 & $\mathrm{~F} \theta \mathrm{b} .5,1930$ & 7.99 & 15,200 \\
\hline 1931 & Jan. 28,1931 & 9.32 & 21,800 \\
\hline 1932 & Feb. 26, 1932 & 15. 83 & 68,500 \\
\hline 1933 & Nov. 13,1932 . & 12. 62 & 42,500 \\
\hline 1934 & Dec. 22, 1933. & 14.40 & 56,600 \\
\hline 1935 & Nov. 5, 1934 & 13. 54 & 49,400 \\
\hline 1936 & June 3, 1936. & 8. 33 & 16,600 \\
\hline $1937 \ldots$ & nen & 8.15 & 15,900 \\
\hline 1938 & 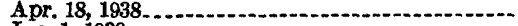 & 10.78 & 29,900 \\
\hline 939 & Jan. 1, 1939 & 9.96 & 25,200 \\
\hline $1940 \ldots \ldots$ & 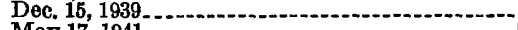 & 9.00 & 20,000 \\
\hline 1941 & May 17, 1941 & $\begin{array}{l}6.80 \\
8.85\end{array}$ & $\begin{array}{r}7,980 \\
19,000\end{array}$ \\
\hline 1943 & Nov. 23,1942 & $\stackrel{0.00}{9.02}$ & 19,500 \\
\hline $1944 \ldots \ldots$ & 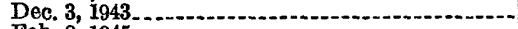 & 10.80 & 29,900 \\
\hline 1945 & 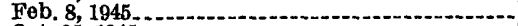 & 10.28 & 26,800 \\
\hline 1946 & Oct. 25,1945 & 9.96 & 25,000 \\
\hline 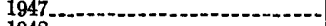 & Oct. 25,1946 & 11.41 & 33,200 \\
\hline 1948 & Oct. 19,1947 & 11.74 & 35,900 \\
\hline 1949 & $\begin{array}{l}\text { May } 13,1949 \\
\text { Nov, } 27,1949\end{array}$ & $\begin{array}{r}9.03 \\
16.93\end{array}$ & $\begin{array}{l}19,700 \\
82,400\end{array}$ \\
\hline 1951. & Feb. 10,1951 & 14. 97 & 62,700 \\
\hline $1952 \ldots$ & (n) & 7.65 & 13,600 \\
\hline 1953 & Jan. 31, 1953 & 10.56 & 28,400 \\
\hline 1954 & Dec. 20, 1953 & 8.17 & 15,600 \\
\hline 1955 & June 11, 1955 & 9.56 & 23,900 \\
\hline 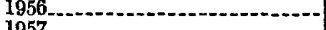 & Oct. 25, 1955 & 12.23 & 40,600 \\
\hline 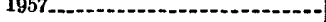 & Dec. 10,1956 & 10.41 & 28,500 \\
\hline
\end{tabular}


22. Baker River below Anderson Creek, near Concrete, Wash.

Location.-Lat $48^{\circ} 39^{\prime} 50^{\prime \prime}$, long $121^{\circ} 40^{\prime} 25^{\prime \prime}$, in SE1/4 sec. 30 , T. 37 N., R. 9 E., on right bank $100 \mathrm{ft}$ downstream from Anderson Creek and 91/2 miles northeast of Concrete.

Drainage area.-211 sq mi.

Gage.-Water-stage recorder. Altitude of gage is $560 \mathrm{ft}$ (from river-profile map). October 22, 1910, to Sept. 23, 1915, staff gage and Sept. 24, 1915, to Nov. 11, 1931, water-stage recorder, $250 \mathrm{ft}$ downstream from present site and at different datum.

Stage-discharge relation.-Defined by current-meter measurements below $8,000 \mathrm{cfs}$ and extended by velocity-area studies.

Annual peak stages and discharges of Baker River below Anderson Creek, near Concrete, Wash.

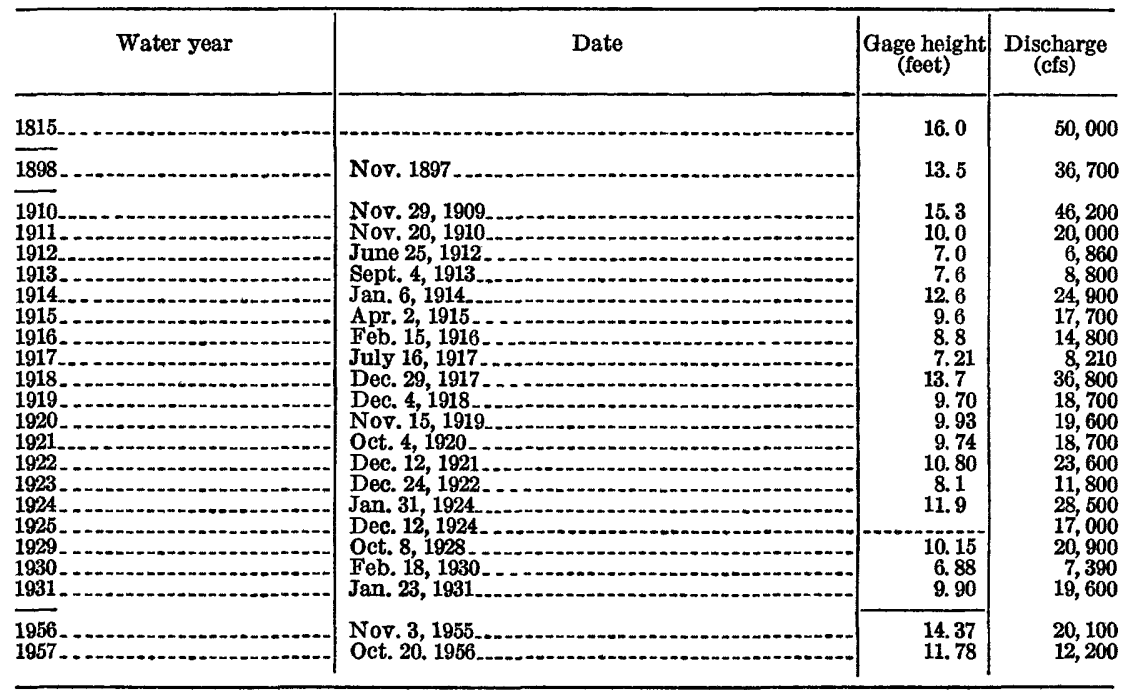




\section{Lake Shannon at Concrete, Wash.}

Location.-Lat $48^{\circ} 32^{\prime} 55^{\prime \prime}$, long $121^{\circ} 44^{\prime} 25^{\prime \prime}$, in SW1/4 sec. 2 , T. 35 N., R. 8 E., at Baker Dam on Baker River near left bank half a mile north of Concrete and 1 mile upstream from mouth of Baker River.

Drainage area. $-297 \mathrm{sq} \mathrm{mi}$.

Gage.-Staff gage or water-stage indicator. Datum of gage is at mean sea level, subject to adjustment to datum of 1929 .

Remarks.-Reservoir is formed by concrete dam completed to elevation 405.00 $\mathrm{ft}$ in November 1925 and to $435.00 \mathrm{ft}$ in June 1927. Storage began in November 1925. Capacity, 132,500 acre-feet between elevation $360 \mathrm{ft}$ (lowest elevation for capacity operation) and $435 \mathrm{ft}$ (spillway crest). Records furnished by Puget Sound Power and Light Co.

Annual peak stages and storage on last day of month of Lake Shannon at Concrete, Wash. 1

\begin{tabular}{|c|c|c|c|}
\hline Water year & Date & $\begin{array}{c}\text { Elevation } \\
\text { (feet, m.s.1.) }\end{array}$ & $\begin{array}{c}\text { Storage } \\
\text { (acre-feet) }\end{array}$ \\
\hline $\begin{array}{l}1926 \\
1927 \\
1929028 \\
1931 \\
1933 \\
1934 \\
1936 \\
1937 \\
1939 \\
19401 \\
1942 \\
1943 \\
1945 \\
1946 \\
1947 \\
1949 \\
1950 \\
1951 \\
1952 \\
1953 \\
1954 \\
1956\end{array}$ & $\begin{array}{l}\text { June } 1926 \\
\text { July } 1927 \\
\text { July } 1928 \\
\text { June } 1929 \\
\text { Jan. } 1931 \\
\text { July } 1932 \\
\text { Nov. } 1932 \\
\text { July } 1934 \\
\text { June } 1934 \\
\text { June } 1936 \\
\text { Nov. } 1937 \\
\text { July } 1939 \\
\text { May } 1940 \\
\text { Jay } 1941 \\
\text { June } 1942 \\
\text { June } 1943 \\
\text { June } 1945 \\
\text { Oct. } 1945 \\
\text { Nov. } 1946 \\
\text { Dec. } 1947 \\
\text { Nov. } 1948 \\
\text { Nov. } 1949 \\
\text { June } 1951 \\
\text { July } 1952 \\
\text { Sept. } 1953 \\
\text { June } 1954 \\
\text { Nov. } 1954 \\
\text { Oct. } 1955 \\
\text { Aug. } 1957\end{array}$ & $\begin{array}{l}404.64 \\
434.68 \\
434.44 \\
434.80 \\
434.95 \\
434.80 \\
434.90 \\
434.80 \\
435.00 \\
434.71 \\
434.97 \\
433.53 \\
434.93 \\
435.00 \\
434.12 \\
434.61 \\
435.60 \\
435.86 \\
435.60 \\
435.59 \\
435.26 \\
435.85 \\
435.88 \\
435.82 \\
435.83 \\
435.89 \\
436.16 \\
436.86 \\
436.55 \\
436.75 \\
436.72 \\
434.81\end{array}$ & $\begin{array}{r}93,350 \\
155,520 \\
154,980 \\
155,790 \\
156,130 \\
155,790 \\
156,020 \\
155,790 \\
156,240 \\
155,590 \\
156,170 \\
152,940 \\
156,080 \\
156,240 \\
154,260 \\
155,360 \\
157,600 \\
158,180 \\
157,600 \\
157,570 \\
156,830 \\
158,160 \\
158,230 \\
158,090 \\
158,120 \\
158,250 \\
158,860 \\
160,450 \\
159,750 \\
160,200 \\
160,130 \\
155,810\end{array}$ \\
\hline
\end{tabular}

1 Figures shown for each water year are maximums of 12 end of month figures. 


\section{Baker River at Concrete, Wash.}

Location.-Lat $48^{\circ} 32^{\prime} 35^{\prime \prime}$, long $121^{\circ} 44^{\prime} 35^{\prime \prime}$, on line between secs. 10 and 11 , T. 35 N., R. 8 E., on left bank $800 \mathrm{ft}$ downstream from Baker River powerplant, a quarter of a mile northeast of Concrete, and three-quarters of a mile upstream from mouth.

Drainage area.-297 sq mi.

Gage.-Water-stage recorder. Datum of gage is $172.6 \mathrm{ft}$ above mean sea level (from river-profile survey). Prior to 1915, staff gage at site half a mile downstream at different datum.

Stage-discharge relation.-Defined by current-meter measurements below 16,000 efs and extended on basis of computation of peak flow over dam and through power plant of $35,200 \mathrm{cfs}$, made by Puget Sound Power and Light Co. for flood of November 27, 1949.

Remarks.-Flow regulated since November 1925 by Baker River powerplant and Lake Shannon.

Annual peak stages and discharges of Baker River at Concrete, Wash.

\begin{tabular}{|c|c|c|c|}
\hline Water year & Date & $\underset{\text { (feet) }}{\text { Gage height }}$ & $\begin{array}{l}\text { Discharge } \\
\text { (cfs) }\end{array}$ \\
\hline 1913 & $\begin{array}{l}\text { Nov. } 21,1910 \\
\text { Nov. } 18,1911 \\
\text { Sept. } 4,1913 \\
\text { Jan. } 6,1914\end{array}$ & $\begin{array}{r}10.8 \\
8.7 \\
9.3 \\
12.2\end{array}$ & $\begin{array}{l}24,600 \\
14,800 \\
18,100 \\
\mathbf{3 1}, 000\end{array}$ \\
\hline $\begin{array}{l}1944 \\
1946 \\
1948 \\
1949 \\
1950 \\
1951 \\
1953 \\
19556\end{array}$ & $\begin{array}{l}\text { Dec. } 3,1943 \\
\text { Feb. } 8,1945 \\
\text { Oct. } 25,1945 \\
\text { Oct. } 24,1946 \\
\text { Oct. } 18,1947 \\
\text { May } 10,1949 \\
\text { Nov. } 27,1949 \\
\text { Feb. } 10,1951 \\
\text { Oct. } 19,1951 \\
\text { Jan. } 12,1953 \\
\text { Oct. } 31,1953 \\
\text { Nov. } 18,1954 \\
\text { Nov. } 4,1955 \\
\text { Oct. } 17,1956\end{array}$ & $\begin{array}{r}10.7 \\
12.45 \\
14.90 \\
12.40 \\
13.40 \\
10.30 \\
20.32 \\
16.20 \\
9.87 \\
11.22 \\
10.55 \\
11.99 \\
15.07 \\
12.67\end{array}$ & $\begin{array}{l}14,100 \\
20,000 \\
27,000 \\
20,000 \\
23,000 \\
12,600 \\
35,200 \\
29,700 \\
11,000 \\
16,200 \\
14,200 \\
18,500 \\
26,900 \\
20,400\end{array}$ \\
\hline
\end{tabular}




\section{Skagit River near Concrete, Wash.}

Location.-Lat $48^{\circ} 31^{\prime} 30^{\prime \prime}$, long $121^{\circ} 46^{\prime} 10^{\prime \prime}$, in NE1/4 sec. 16, T. 35 N., R. 8 E., on right bank at The Dalles $1 \frac{1}{2}$ miles southwest of Concrete and $2 \frac{1}{2}$ miles downstream from Baker River.

Drainage area.-2,700 sq mi, approximately, of which $400 \mathrm{sq} \mathrm{mi}$ is in Canada. Gage:-Water-stage recorder. Datum of gage is $130.0 \mathrm{ft}$ above mean sea level, datum of 1929. Dec. 10, 1924, to Oct. 27, 1937, water-stage recorder at present site, at datum $12.69 \mathrm{ft}$ higher. Gage heights given herein are to datum of present gage.

Stage-discharge relation.-Defined by current-meter measurements below 135,000 efs and extended by logarithmic plotting.

Remarks.-Flow partly regulated by powerplants on Baker and upper Skagit Rivers and by Lake Shannon Reservoir since 1926, Diablo Reservoir since 1930, and Ross Reservoir since 1940.

Annual peak stages and discharges of Skagit River near Concrete, Wash.

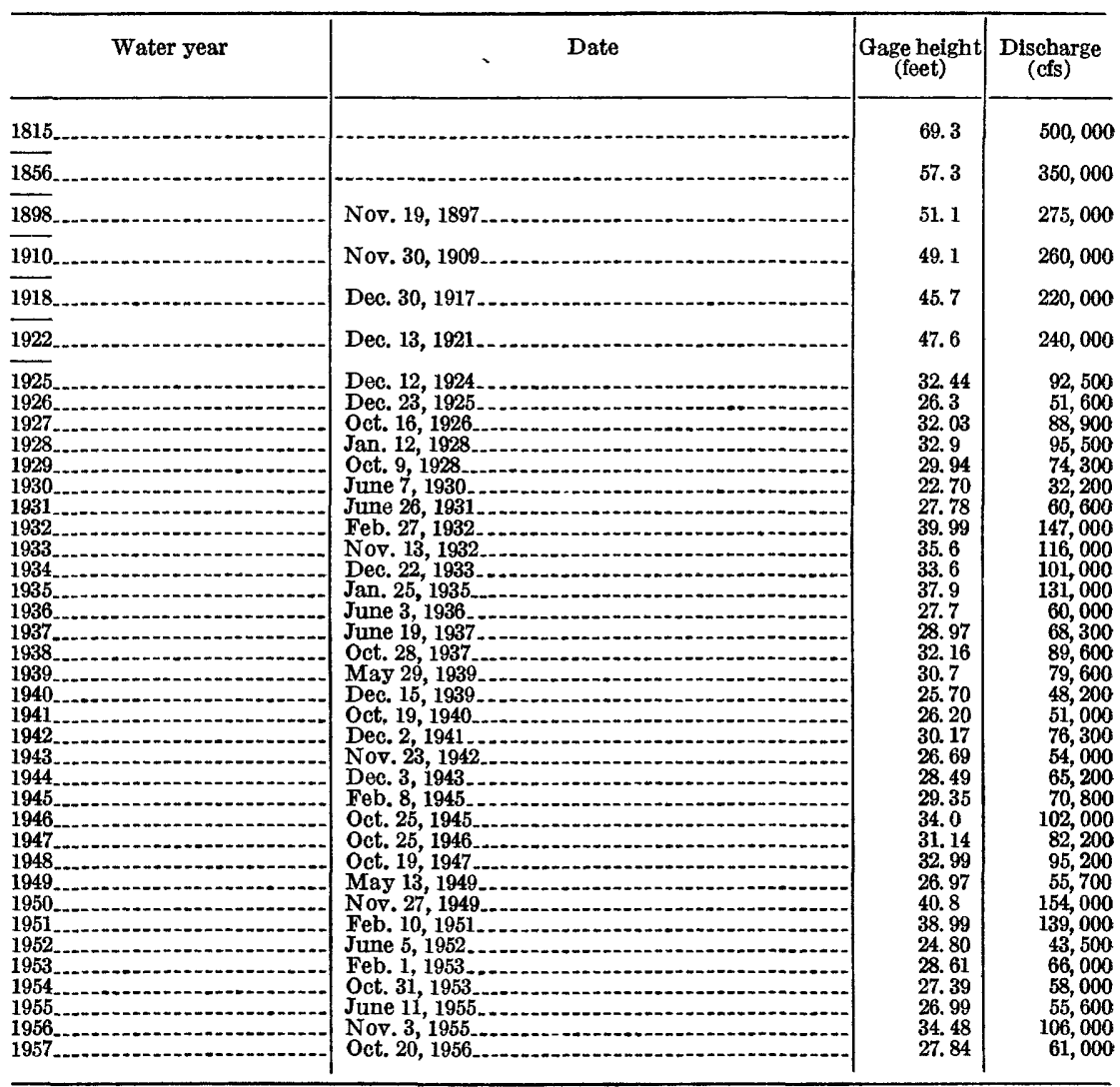


26. Alder Creek near Hamilton, Wash.

Location.-Lat $48^{\circ} 31^{\prime} 40^{\prime \prime}$, long $121^{\circ} 57^{\prime} 00^{\prime \prime}$, in NEY/4 sec. 18 , T. 35 N., R. 7 E., on left bank at railroad trestle a quarter of a mile upstream from highway bridge, three-quarters of a mile upstream from mouth, and 2 miles east of Hamilton.

Drainage area. $-10.7 \mathrm{sq} \mathrm{mi}$.

Gage.-Water-stage recorder. Altitude of gage is $125 \mathrm{ft}$ (by barometer). Prior to Nov. 15, 1945, water-stage recorder at site $80 \mathrm{ft}$ upstream at datum 2.46 ft higher. Nov. 15, 1945, to Jan. 7, 1947, water-stage recorder at present site at datum $2.56 \mathrm{ft}$ higher. Jan. 8, 1947, to Aug. 24, 1951, water-stage recorder at same site at datum $0.98 \mathrm{ft}$ higher. Gage heights given herein are to datum of present gage.

Stage-discharge relation.-Defined by current-meter measurements below $400 \mathrm{cfs}$ and extended by logarithmic plotting.

Annual peak stages and discharges of Alder Creek near Hamilton, Wash.

\begin{tabular}{|c|c|c|c|}
\hline Water year & Date & $\underset{\text { (feet) }}{\text { Gage height }}$ & $\begin{array}{c}\text { Discharge } \\
\text { (cfs) }\end{array}$ \\
\hline 1946 (1945 1946 & $\begin{array}{l}\text { Dec. } 3,1943 \\
\text { Jan. } 7,1945 \\
\text { Oct. } 25,1945 \\
\text { Dec. } 11,1946 . \\
\text { Oct. } 19,1947 \\
\text { Dec. } 1,1948 \\
\text { Dec. } 27,1949 \\
\text { Feb. } 10,1951 \\
\text { Feb. } 4,1952 \\
\text { Jan. } 31,1953 \\
\text { Dec. } 11,1953 . \\
\text { Feb. } 8,1955 \\
\text { Nov. } 3,1955 \\
\text { Dec. } 9,1956\end{array}$ & $\begin{array}{l}5.38 \\
6.74 \\
5.93 \\
5.17 \\
3.55 \\
3.75 \\
4.24 \\
4.90 \\
\text { 3. } 56 \\
4.23 \\
3.80 \\
3.84 \\
4.11 \\
5.38\end{array}$ & $\begin{array}{l}137 \\
670 \\
265 \\
450 \\
241 \\
256 \\
477 \\
654 \\
212 \\
364 \\
239 \\
295 \\
363 \\
360\end{array}$ \\
\hline
\end{tabular}

\section{Day Creek near Lyman, Wash.}

Location.-Lat $48^{\circ} 30^{\prime} 05^{\prime \prime}$, long $122^{\circ} 02^{\prime} 45^{\prime \prime}$, in NW1/4 sec. 28 , T. 35 N., R. 6 E., on left end of county highway bridge, 1 mile upstream from mouth, and $13 / 4$ miles southeast of Lyman.

Drainage area.-36.3 sq mi.

Gage.-Water-stage recorder. Altitude of gage is $90 \mathrm{ft}$ (from topographic map). Stage-discharge relation.-Defined by current-meter measurements below 3,000 cfs and extended by logarithmic plotting.

Annual peak stages and discharges of Day Creek near Lyman, Wash.

\begin{tabular}{|c|c|c|c|}
\hline Water year & Date & ${ }_{\text {(feet) }}^{\text {Gage height }}$ & $\begin{array}{c}\text { Discharge } \\
\text { (cfs) }\end{array}$ \\
\hline $\begin{array}{l}1944 \\
1945 \\
1948 \\
1949 \\
1950 \\
1951 \\
1953 \\
1954 \\
1956\end{array}$ & 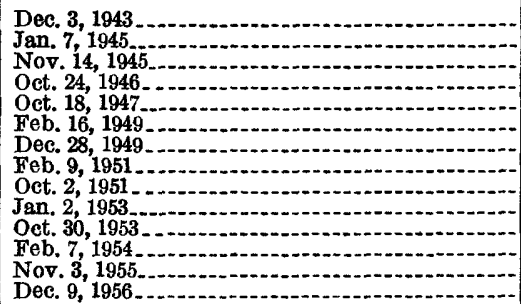 & $\begin{array}{l}7.60 \\
7.85 \\
7.77 \\
8.12 \\
7.94 \\
6.85 \\
8.35 \\
7.72 \\
6.55 \\
6.81 \\
7.07 \\
6.47 \\
8.27 \\
8.80\end{array}$ & $\begin{array}{l}4,370 \\
4,310 \\
4,310 \\
4,530 \\
4,420 \\
3,330 \\
5,570 \\
4,510 \\
3,350 \\
3,890 \\
4,180 \\
3,750 \\
4,750 \\
5,360\end{array}$ \\
\hline
\end{tabular}




\section{Skagit River near Sedro Woolley, Wash.}

Location.-Lat $48^{\circ} 29^{\prime} 05^{\prime \prime}$, long $122^{\circ} 14^{\prime} 30^{\prime \prime}$, in NW1/4 sec. 36, T. 35 N., R. 4 E.' at Northern Pacific Railway bridge, three-quarters of a mile downstream from entrance to Beatty Slough, and 1/1/2 miles south of Sedro Woolley.

Drainage area.- $3,000 \mathrm{sq} \mathrm{mi}$, approximately, of which $400 \mathrm{sq} \mathrm{mi}$ is in Canada. Gage.-Staff or chain gages. Datum of gage is extreme low sea level in Puget

Sound (levels by Corps of Engineers), which is $8.93 \mathrm{ft}$ below mean sea level, unadjusted.

Stage-discharge relation.-Defined by current-meter measurements below 91,000 cfs and extended by logarithmic plotting.

Remarks.-Flow in Beatty's slough is included in this record.

Annual peak stages and discharges of Skagit River near Sedro Woolley, Wash.

\begin{tabular}{|c|c|c|c|}
\hline Water year & Date & $\underset{\text { (feet) }}{\text { Gage height }}$ & $\underset{\text { (cfs) }}{\text { Discharge }}$ \\
\hline 1815 & & 63.5 & 400,000 \\
\hline$\overline{1856 .}$ & & 60.0 & 300,000 \\
\hline 1897 & $\begin{array}{l}\text { Nov. } 16,1896 \ldots \ldots \\
\text { Nov. } 19,1897 \ldots \ldots\end{array}$ & $\begin{array}{l}54.8 \\
54.9\end{array}$ & $\begin{array}{l}185,000 \\
190,000\end{array}$ \\
\hline 1907 & 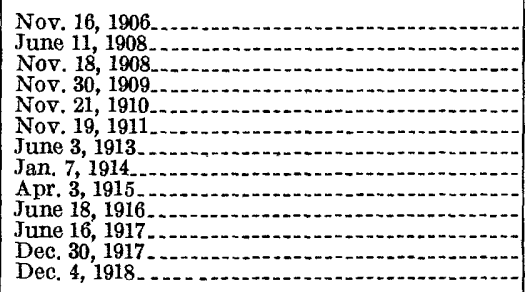 & $\begin{array}{l}54.7 \\
47.8 \\
52.0 \\
56.5 \\
52.1 \\
48.4 \\
46.4 \\
49.6 \\
45.4 \\
46.5 \\
44.4 \\
54.1 \\
47.0\end{array}$ & $\begin{array}{r}180,000 \\
48,200 \\
97,000 \\
220,000 \\
114,000 \\
66,600 \\
70,800 \\
104,000 \\
67,300 \\
75,800 \\
60,400 \\
195,000 \\
80,200\end{array}$ \\
\hline$\overline{1922}$ & $\begin{array}{l}\text { Dec. } 13,1921 \\
\text { Dec. } 25,1922, \ldots\end{array}$ & $\begin{array}{l}54.3 \\
45.2\end{array}$ & $\begin{array}{r}210,000 \\
71,000\end{array}$ \\
\hline
\end{tabular}

29. East Fork Nookachamps Creek near Clear Lake, Wash.

Location.-Lat $48^{\circ} 25^{\prime} 30^{\prime \prime}$, long $122^{\circ} 12^{\prime} 30^{\prime \prime}$, in NE1/4 sec. 19, T. 34 N., R. 5 E., at county road bridge, 3 miles southeast of Clear Lake, and $31 / 2$ miles upstream from mouth.

Drainage area.-20.5 sq mi.

Gage.-Staff gage. Gage heights are from graph based on gage readings. Altitude of gage is $70 \mathrm{ft}$ (from topographic map).

Stage-discharge relation.-Defined by current-meter measurements below 1,900 efs and extended by logarithmic plotting.

Annual peak stages and discharges of East Fork Nookachamps Creek near Clear Lake, Wash.

\begin{tabular}{|c|c|c|c|}
\hline Water year & Date & $\underset{\text { (feet) }}{\text { Gage height }}$ & $\begin{array}{c}\text { Discharge } \\
\text { (cfs) }\end{array}$ \\
\hline 1946 & $\begin{array}{l}\text { Jan. } 7,1945 \\
\text { Oct. } 25,1945 \\
\text { Oct. } 24,1946 \\
\text { Oct. } 19,1947 \\
\text { Feb. } 17,1949 \\
\text { Dec. } 28,1949\end{array}$ & $\begin{array}{l}8.59 \\
10.3 \\
110.0 \\
10.33 \\
10.05 \\
9.39\end{array}$ & $\begin{array}{r}2,000 \\
2,710 \\
12,120 \\
2,220 \\
2,130 \\
2,010\end{array}$ \\
\hline
\end{tabular}

1 Estimated. 
30. Skagit River near Mount Vernon, Wash.

Location.-Lat $48^{\circ} 26^{\prime} 40^{\prime \prime}$, long $122^{\circ} 20^{\prime} 00^{\prime \prime}$, in SE1/4 sec. 7, T. 34 N., R. 4 E., on drawrest of and $150 \mathrm{ft}$ downstream from bridge on U.S. Highway 99 and 1 mile north of Mount Vernon.

Drainage area.-3,060 sq mi, approximately, of which $400 \mathrm{sq} \mathrm{mi}$ is in Canada.

Gage.-Water-stage recorder and, since Sept. 28, 1951, a crest-stage indicator. Datum of gage is at mean sea level, datum of 1929.

Stage-discharge relation.-Defined by current meter measurements below 144,000 cfs.

Remarks.-Flow partly regulated by powerplants on Baker and upper Skagit Rivers, and by Lake Shannon, Diablo, and Ross Reservoirs.

Annual peak stages and discharges of Skagit River near Mount Vernon, Wash

\begin{tabular}{|c|c|c|c|}
\hline Water year & Date & $\underset{\text { (feet) }}{\text { Gage height }}$ & $\begin{array}{c}\text { Discharge } \\
\text { (cfs) }\end{array}$ \\
\hline 1907. & - & 37 & 180,000 \\
\hline 1941. & Oct. $20,1940$. & & 144,000 \\
\hline 1942. & Dec. 3,1941 & 25.99 & 65,300 \\
\hline 1943 & June 18,1943 & 22.92 & 47,000 \\
\hline (n) & Dec. 3,1943 & 24.40 & 55,700 \\
\hline 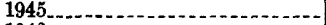 & Feb. 8,1945 & 25. 77 & 59,800 \\
\hline 1946 & Oct. 26,1945 & 30.25 & 94,300 \\
\hline $1947 \ldots \ldots+2$. & Oct. 25, 1946 & 27.8 & 64,900 \\
\hline 1948 & Oct. 19,1947 & 28. 68 & 69,400 \\
\hline 1949 & May 13,1949 & $\begin{array}{l}26.05 \\
34.21\end{array}$ & $\begin{array}{r}56,200 \\
114,000\end{array}$ \\
\hline 1951 & 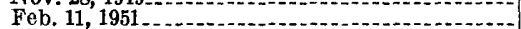 & 36.85 & 144,000 \\
\hline 1952 & June $5,1952 \ldots \ldots$ & 22. 43 & 41,400 \\
\hline $1953 \ldots$ & Feb. 1, 1953 & 27.76 & 65,700 \\
\hline $1954 \ldots$ & Nov. 1,1953 & 26. 37 & 57,900 \\
\hline 1955 & 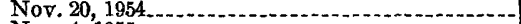 & 27.10 & 62,000 \\
\hline $1956 \ldots$ & Nov, 4, 1955 & 33. 52 & 107,000 \\
\hline $1957 \ldots$ & Oct. 21, 1956 & 27.47 & 64,000 \\
\hline
\end{tabular}

1 Maximum day.

\section{FREQUENCY OF FLOODS}

\section{SINGLE STATION FREQUENCY}

Studies made by Benson (1960), and others, indicate that a long record is necessary before a reliable flood-frequency curve can be drawn. In order to come within 10 percent of the correct value 95 percent of the time for a 50-year flood, a length of record of about 110 years is required. In fact, to obtain this accuracy for even a 10-year flood required 90 years of record. However, to come within 25 percent of the correct value 95 percent of the time only about 39 years are required. To obtain this accuracy for a 10-year flood required only 18 years. This study points out the undesirability of using a short record at a single station for constructing a frequency curve. For this reason historic data have been included whenever possible to lengthen the record. By using certain floods back to 1815 , a synthetic 143-year record was obtained. 


\section{FREQUENCY SERIES}

Two types of flood series are the partial-duration series, based upon all floods above a selected base discharge without regard to the number of floods that occur in any one year, and the annual-flood series, based upon the highest flood that occurs each year. There are objections to both types. The partial-duration series may include floods that are not independent events, that is, the first flood sets the stage for the one closely following. The annual-flood series, however, may omit a second independent flood in a year that may be greater than many annual floods of other years. Both series give essentially the same results for recurrence intervals greater than 10 years.

The following table, derived from the statistical relationship between the two series, shows comparative values of recurrence intervals by the two methods:

Recurrence intervals, in years

\begin{tabular}{|c|c|c|c|}
\hline Annual-flood series & $\begin{array}{c}\text { Partial-duration } \\
\text { series }\end{array}$ & Annual-flood series & $\begin{array}{l}\text { Partial-duration } \\
\text { series }\end{array}$ \\
\hline $\begin{array}{l}1.16 \\
1.58 \\
2.00 \\
5.52\end{array}$ & $\begin{array}{l}0.50 \\
1.00 \\
1.45 \\
2.0 \\
5.0\end{array}$ & $\begin{array}{l}10.5 \\
20.50 .5 \\
50.5 \\
100.5\end{array}$ & $\begin{array}{r}10.0 \\
20.0 \\
500 \\
100.0\end{array}$ \\
\hline
\end{tabular}

There is an important distinction between the recurrence intervals of the two series. In the annual-flood series the recurrence interval is the average interval of time in which a flood of given size will be equalled or exceeded as an annual maximum. In the partial-duration series the recurrence interval is the average interval of time in which a flood of given size will be equaled or exceeded without regard to its relation to any period of time.

The annual-flood series has been used in this study. When it is important to know how often, on the average, a stream will exceed a certain discharge (as when designing a low fill, which will be overflowed during high floods), the partial duration series must be used. In such a case the use of the relationship expressed in the preceding table for converting the annual-flood series to the partial-duration series recurrence intervals will be entirely adequate.

\section{PLotTing posimtons}

For plotting data based on the annual-flood series, the highest observed peak in each water year is listed in chronological order. Only complete years of stream-flow records should be used except in cases where a flood that occurs during a period of partial record is known to be the highest during the year. Also, historical flood data 
can often be used to advantage, and particularly to assist in defining the upper end of the frequency curve.

Numbers are assigned to each flood in the order of decreasing magnitude; the largest is designated as number one. Appropriate recurrence intervals are then assigned to each flood; they depend upon the order number, the period of record, and any additional historical information indicating the frequency recurrence.

Recurrence intervals, $T$ (time in years), are computed from the formula $(n+1) / m$, where $n$ equals the number of years of record and $m$ equals the order of relative magnitude of the flood beginning with the highest as one. This formula is simple to compute, is applicable both to the annual-flood series and the partial-duration series, and gives results that conform with some of the latest theories.

Annual floods are plotted on a special graph based on the theory of extreme values for analysis of flood frequencies. On this plot the discharge having a recurrence interval of 2.33 years is the same as the arithmetical mean of an infinitely long series of annual floods and is known as the "mean annual flood." With relatively short records, such as are treated here, the "mean annual flood" is determined graphically from the gaging-station flood-frequency curves as the value of the discharge at a recurrence interval of 2.33 years.

\section{HUSTORICAL DATA}

Historical data are of particular value where there is an account of all floods above a certain stage over a long period antedating the beginning of the stream-gaging record. The minimum or base stage covered by a historical account is generally high; more often it corresponds to flood stage, the stage where damage begins. Such a list of historical floods is in the nature of a partial-duration series above a high base; but, as there generally is only one flood of such magnitude in any one year, it may also be considered to be a partial list of annual floods. In either case the treatment is the same.

All floods, both historical and recorded, should be listed together and assigned recurrence intervals in the same manner as previously discussed, except that for individual historical floods the period of time for which they are known to be the highest must be considered.

In this report a 143-year base period (1815-1957) was used for the historical data because the flood of 1815 was known to have been higher than any since that date. It was assigned order number 1 . In some cases the flood of 1856 was known to be the second highest flood and was given the order number 2. All other floods were assigned order numbers based on the period of time they were known to be 1st, 2nd, 3rd, highest, and so on. 
In this report the historical floods were included in the data for the definition of frequency curves even though in some cases the natural regimen of the streams has been changed somewhat by the construction of dams to create storage reservoirs. As it has been stated previously, the Skagit River can now be almost completely controlled at Newhalem by Ross Reservoir.

The six stations where historic data are available for use are as follows:

Skagit River at Newhalem, Wash.

Cascade River at Marblemount, Wash.

Sauk River at Darrington, Wash.

Baker River below Anderson Creek, near Concrete, Wash.

Skagit River near Concrete, Wash.

Skagit River near Sedro Woolley, Wash.

Historic information was obtained for Skagit River at Reflector Bar, near Newhalem, but data for this station are for all practical purposes identical to that obtained at Newhalem so they were not used. Examples of the plotting of data for single station frequency curves, using historic information, are shown in the last part of this report. (See figs. 12 to 17 .)

\section{FTITING FREQUENCY GRAPHS}

A curve must be fitted to the data after a frequency diagram has been plotted. Many frequency curves tend to plot as straight lines on special plotting paper, which is a desirable feature if extrapolation can be justified. However, the use of the frequency graph for purposes of extrapolation may lead to fallacious results because the linear distance from 25 to 200 years is deceptively short on the plotting diagram and the error of a curve fitted by any method may be extremely great at its outer end. The data, not the functional theory, are used to define the graph so extrapolation can be justified only when the phenomena have proved to conform to the underlying law.

It is the practice of the Geological Survey to draw a visually-fitted line, either straight or curved, depending upon which best fits the plotted points. Sharp breaks in a curve are avoided by not giving full weight to the floods with the larger recurrence intervals because their true recurrence interval is seldom, if ever, accurately known. Thus it will be found that the curve as drawn may not pass through points that represent the one or two floods of largest magnitude.

\section{REGIONAL FREQUENCY}

A single-station frequency curve, particularly for the short records available, is a random sample and may not be truly representative of a region of like characteristics. For this reason a method of combining records for a number of stations has been developed to define a 
composite curve of median values to be applied to a basin or region as a whole.

\section{SELECTION OF BASE PERIOD}

In order that records of different lengths may be compared, it is necessary to select a common base period of record, either one that is common to all records or one to wbich such records may be extended. The base used herein is the 143-year period, 1815-1957; records for six stations were available. The 29-year period 1929-57 was also considered as a base for combining other station records in the basin, but it was not used because there was not enough record for the 1929-57 period at the six long-term stations to develop a reliable method of combining the results from the two base periods. The short-term period was used in the determination of mean annual floods.

\section{Comparatre MeANS}

The value of the mean annual flood will vary with the length of the record from which it is derived and will be dissimilar for different periods of record even though the same number of years is being considered. For example, the mean annual flood obtained for the 10-year period of record 1936-45 for Cascade River at Marblemount would be lower than the mean annual flood for the period 1946-55 because the peaks are of lesser magnitude during the earlier period. Also, the mean annual flood for the 20-year period 1936-55 would differ from both of the two 10-year period values and be somewhere between them. As the record increases in length, the mean annual flood can be determined more accurately.

The mean annual flood is the average of the maximum annual floods. It is determined graphically for each frequency distribution by the intersection of the visually best-fitting frequency curve and the mean line (the line corresponding to the 2.33-year recurrence interval).

For a flood record of length equal to that of the selected base period, the mean annual flood is obtained directly from the frequency graph. For stations where only a few years of record are missing, the mean annual flood is obtained for the base period in the following manner: peak discharges for the missing years of record are estimated by the correlation of floods at that station with those of nearby longterm stations. Order numbers may then be assigned to all peaks, but only those for actual years of record are plotted on the graph. The mean annual flood (adjusted) is then determined graphically in the usual manner. For short-term stations the method used is to compute the mean annual flood for the actual period of the shortterm station and then to adjust this value to the base period on the basis of the ratio of the mean annual flood for the same short period 
at a nearby long-term station to the mean annual flood of the base period for the long-term station.

\section{TEST FOR HOMOGENETTY}

A test for homogeneity of records is necessary before a group of stations are combined. The test is statistical and is applied to the slopes of the individual frequency graphs to determine whether deviations from an average slope are such as may be due to chance alone.

The test was based upon the slope of the frequency curve determined by the ratio of the flood with a 10-year recurrence interval to the mean annual flood (2.33-year recurrence interval) at each station. The ratios thus obtained were averaged and the mean annual flood at each station was multiplied by the average value. The recurrence interval for this flood discharge was then determined and tested by statistical methods to determine that it would fall between permissible limiting values 95 percent of the time.

The six stations considered were found to be within these limits which indicated that they were homogeneous and could be combined.

\section{COMBINING RECORDS}

In order to combine the records to get a single median frequency curve it was necessary to express the frequency curve data in dimensionless terms. This was done by dividing the discharge at certain recurrence intervals at each station by the adjusted mean annual flood. This provided, at each station, a list of ratios for the designated recurrence intervals.

Median values for each of these recurrence intervals were computed for the 143-year base period. The medians were plotted on the frequency chart to define a composite flood-frequency curve, based upon the combined records and applicable to all streams within the basin; this curve is presented as figure 7 . The composite curve is considered

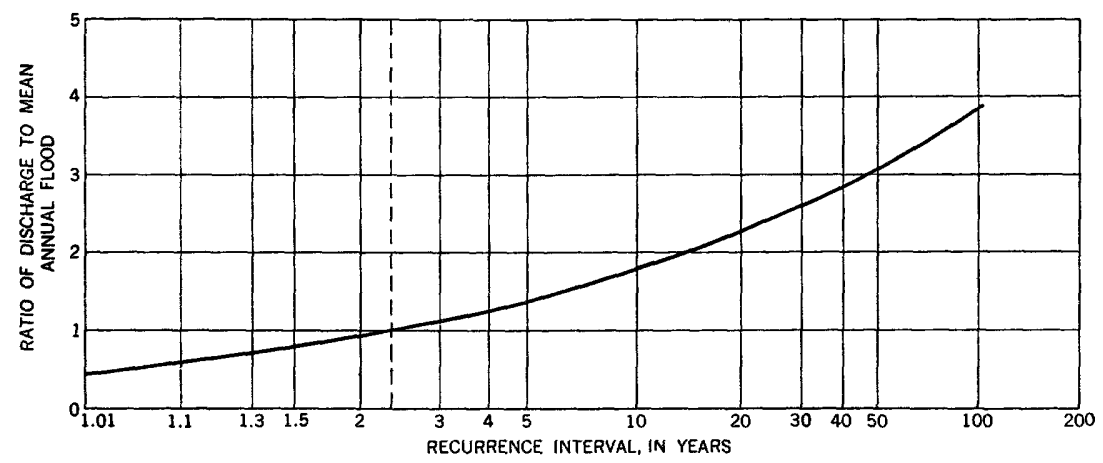

FIGURe 7.-Composite flood-frequency curve, Skagit River basin. 
reliable to 50 years and fairly reliable to 100 years, but it should be extended furtber only with extreme caution.

Bodhaine and Robinson (1952) developed a composite frequency curve from the combination of 131 records from western Washington. The curve was based on a 40-year base period and, therefore, is different from the curve in this report. The change in the curve results from the use of the historic data. The Skagit River basin is the only area in the State where data have been collected for the historic floods of 1815 and 1856; additional data were also obtained at several stations in the basin for unrecorded extreme floods of November 1897 and November 1909. These data could not be used in a statewide analysis because they were only known to have occurred in the Skagit River basin. Since the composite curve of this report varies considerably from the curves computed for other areas, its use should be confined to the Skagit River basin.

\section{FLOOD-FREQUENCY RELATIONSHAPS}

In order that the composite curve may be used anywhere within the Skagit River basin, it is necessary to correlate the mean annual flood with some readily determinable physical characteristic of the drainage areas. Many characteristics that affect runoff (and consequently the mean annual flood) have been found by other investigators. Among these characteristics are size of drainage area, topography, type of soil, vegetation, stream slopes, lakes, elevation, rainfall, shape of basin, and others. Of these, the major characteristic and the one most easily determined is the size of the drainage area. Lack of adequate topographic maps prevents the determination and, consequently, the use of some of the above characteristics in a statistical study. The effects of others, such as rainfall and shape of basin, show such poor relations that they are of no material value.

The values of the mean annual floods mentioned previously under "Comparable means" were plotted against drainage area, on logarithmic graph paper, for each of the stations used in this study. The plotted points scatter considerably but may be divided into groups in which the relations vary in accordance with a series of three curves, each defined by various combinations of main stem and tributary stations; these curves are presented as figure 8 , and areas to which each apply are shown on plate 1 . The fact that three curves, rather than one, are defined reflects the influence of drainage basin characteristics, other than size of area, that may or may not be definable.

Bodbaine and Robinson (1952) show the same general grouping of streams as does this study. Size of drainage area was considered the primary factor in the present study because it has the greatest effect on the mean annual floods. The other characteristics that were 


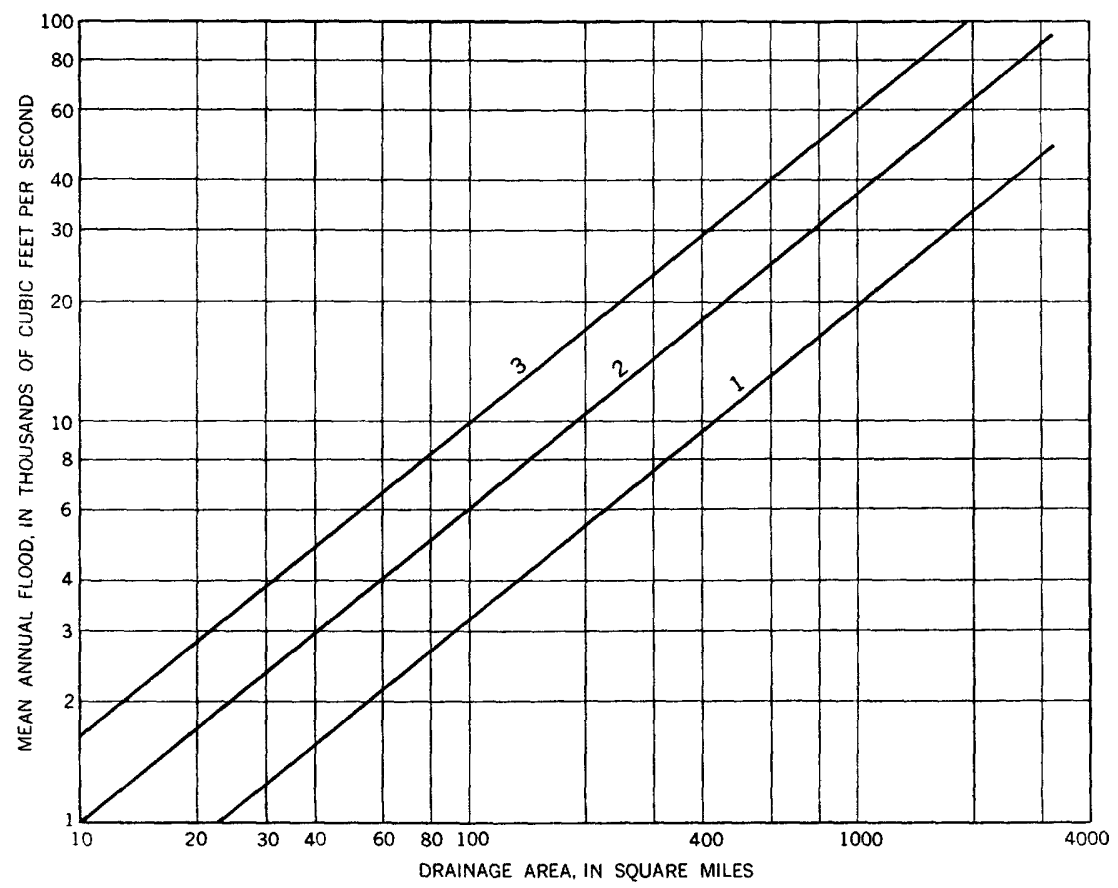

FIGURE 8.-Variation of mean annual flood with drainage area.

used-elevations of drainage basin, geographical factor, and area of lakes and ponds-also have an effect on the mean annual floods. The range in mean elevation of the drainage areas of the streams under consideration in the Skagit River basin is so small that a correlation with this factor cannot be made. The geographical factor is portrayed by the three curves shown in figure 8. The effect of lakes and ponds is small so this factor has not been considered.

The curves shown in figure 8 should not be extrapolated beyond the limits of the available data because to do so may lead to serious error. For additional study of drainage basin characteristics, see the publications listed in the bibliography.

\section{FLOOD-FREQUENCY CURVES}

To define a frequency curve at any place in the Skagit River basin: 1. Measure size of drainage basin, in square miles, above place where information is wanted.

2. Locate stream in one of the three mean annual flood areas (pl. 1).

3. Determine mean annual flood, in cubic feet per second, from proper curve of figure 8 . 
4. Determine discharge in ratio to mean annual flood for several recurrence intervals, from figure 7.

5. Multiply the mean annual flood determined in step 3, by the ratios determined in step 4 , to get the discharge corresponding to various recurrence intervals.

6. Plot discharges determined in step 5 and draw frequency curve.

Flood-frequency curves for six stations where historical data are available are presented in figures 9-14. The curves shown on each plot are computed from the composite frequency curve, shown on figure 7. The mean annual flood curve, shown on figure 8 , serves as a means of comparing the actual data for each station with the average or computed curve.

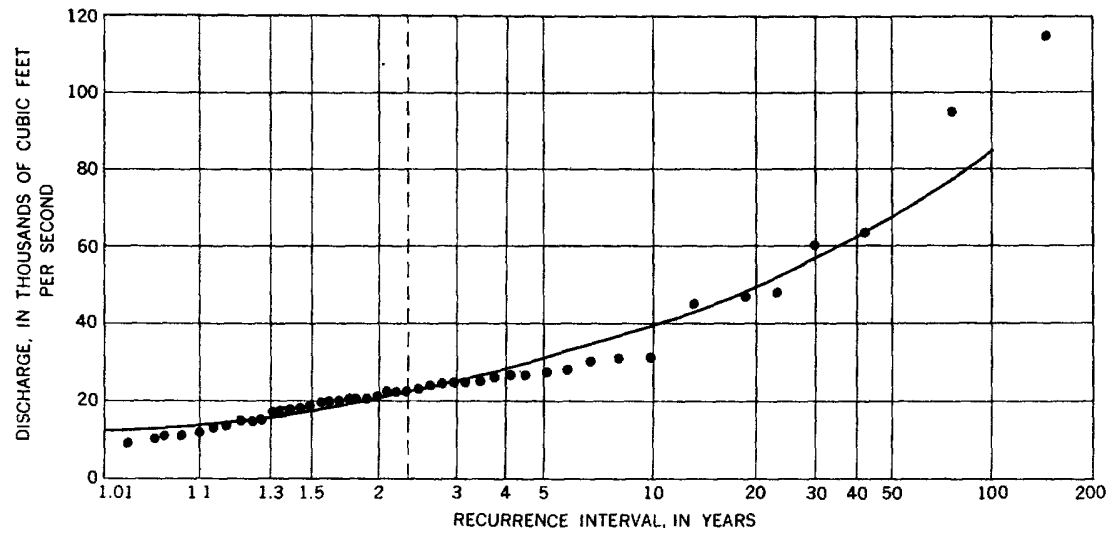

Fifire 9.-Frequency of annual floods, Skagit River at Newhalem, Wash.

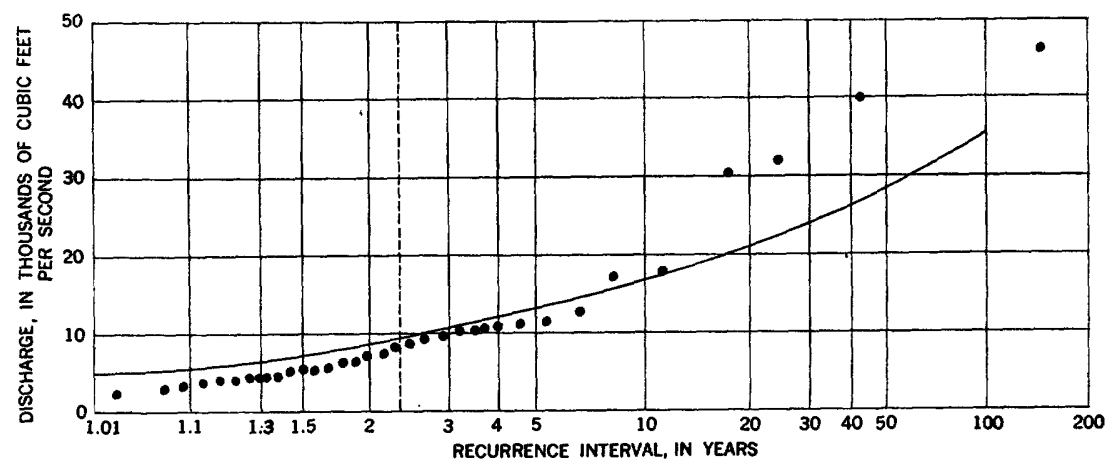

Figure 10.-Frequency of annual floods, Cascade River at Marblemount, Wash. 


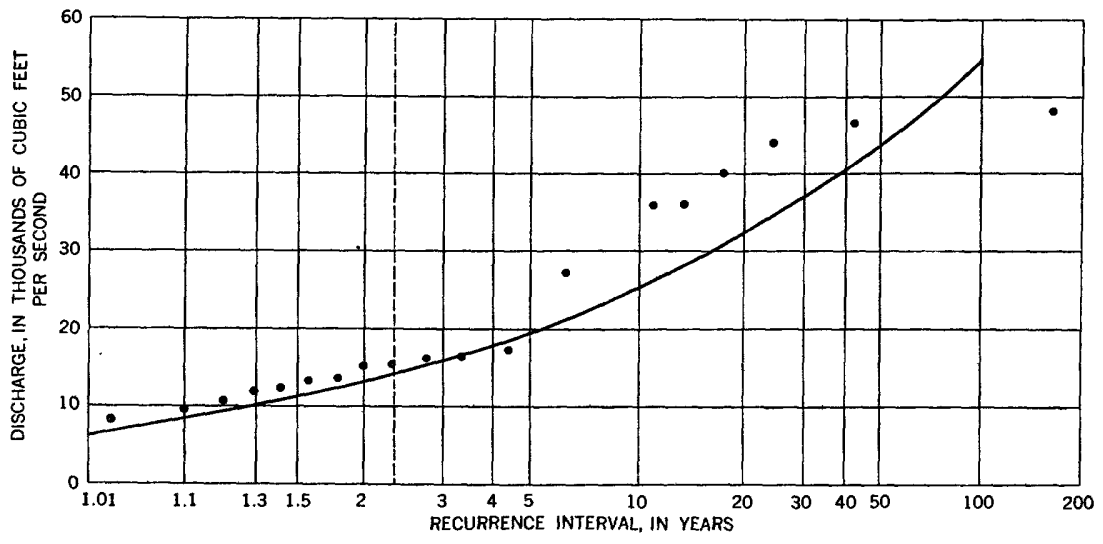

Figure 11,-Frequency of annual floods, Sauk River at Darrington, Wash.

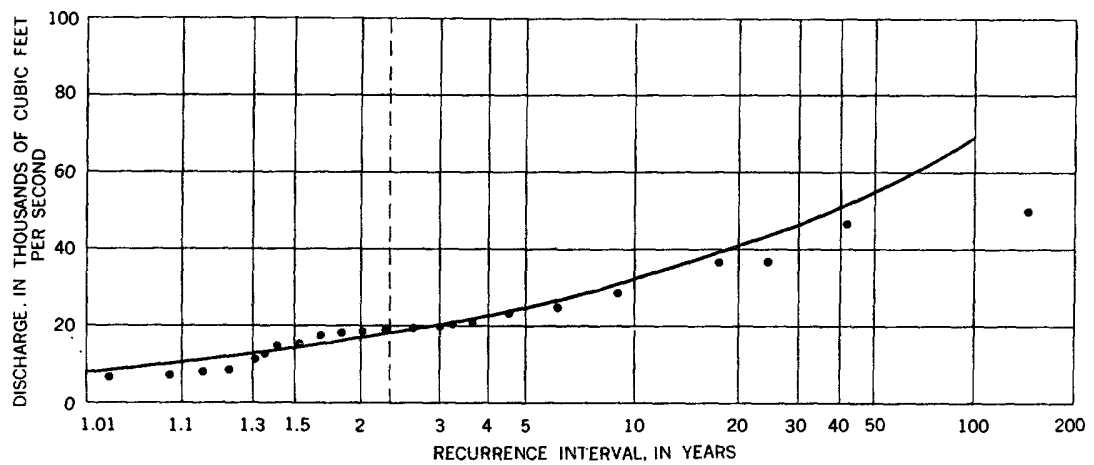

Figune 12.-Frequency of annual floods, Baker River below Anderson Creek, near Concrete, Wash.

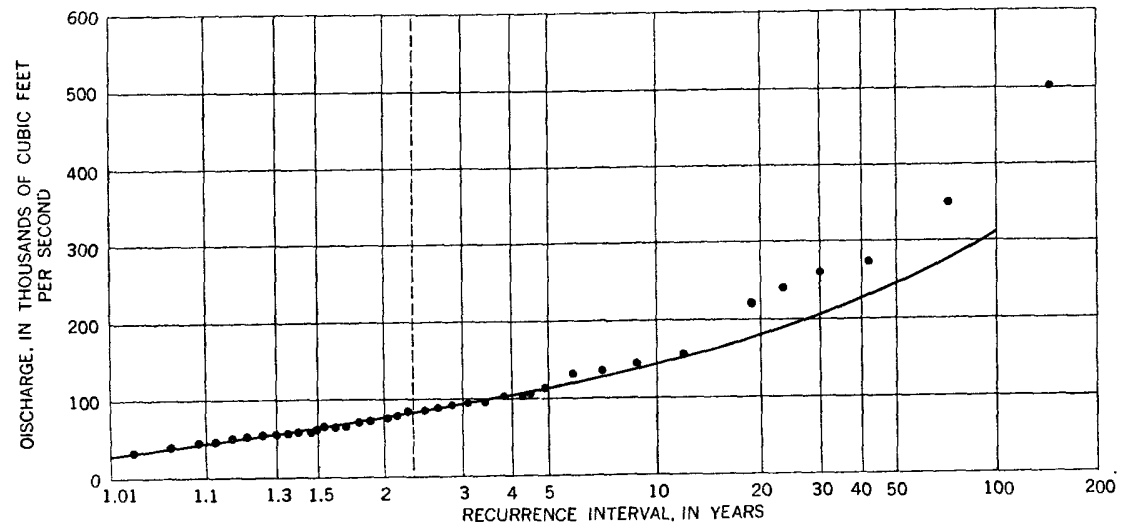

FigURE 13.-Frequency of annual floods, Skagit Rlver near Concrete, Wash. 


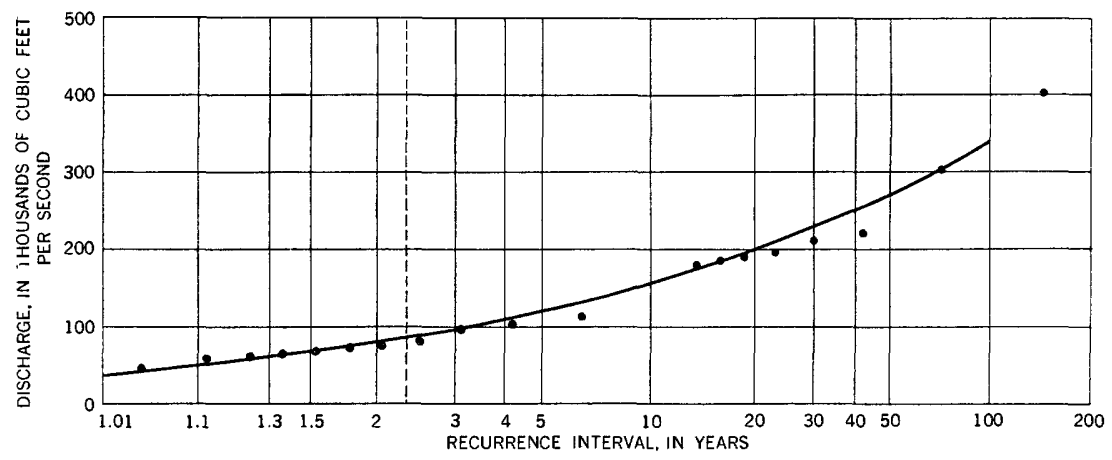

FIgURE 14.-Frequency of annual floods, Skagit River near Sedro Woolley, Wash.

\section{SELECTED BIBLIOGRAPHY}

Benson, M. A., 1960, Characteristics of frequency curves based on a theoretical 1,000-year record, in Flood-frequency analyses: U.S. Geol. Survey WaterSupply Paper 1543-A, p. 51-74.

Bodhaine, G. L., and Robinson, W. H., 1952, Floods in western Washington, frequency and magnitude in relation to drainage basin characteristics: U.S. Geol. Survey Circ. 191, 124 p.

Carter, R. W., 1951, Floods in Georgia, frequency and magnitude: U.S. Geol. Survey Circ. 100, $127 \mathrm{p}$.

Cragwall, J. S., Jr., 1952, Floods in Louisiana, magnitude and frequency: Louisiana Dept. Highways, 281 p.

Dalrymple, Tate, 1950, Regional flood frequency: Washington, D.C., Highway Research Board, Research Rept. no. 11-B, p. 4-20.

Daly, R. A., 1912, Canada Geol. Survey Dept.: Mines Mem. 38, map 15.

Gumbel, E. J., 1945, Floods estimated by probability method: Eng. News-Rec., v. 134 , no. 24, p. $833-837$.

Langbein, W. B., 1949, Annual floods and the partial-duration series: Am. Geophys. Union Trans., v. 30 , p. 879-881.

Schwob, H. H., 1953, Iowa floods, magnitude and frequency: Iowa Highway Comm., Iowa Highway Research Board Bull. 1, $171 \mathrm{p}$.

Stevens, J. C., LaRue, E. C., and Henshaw, F. F., 1911, Surface-water supply of the United States, pt. 12, North Pacific Coast: U.S. Geol. Survey WaterSupply Paper 272, p. 489.

U.S. Congress, House of Representatives, 1933, Report containing a general plan for the improvement of Skagit River, Washington, for the purposes of navigation and efficient development of its water power, the control of floods, and the needs of irrigation: U.S. 73d Cong., 2d sess., H. Doc. No. 187, 110 p. 



\section{INDEX}

\begin{abstract}
Alder Creek, gaging-station records

Altitude, effect on climate.
\end{abstract}

Bacon Creek, gaging-station records.

Baker, Mount.

Baker Dam

aker River, discharge data

gaging-station records. .....................

Beaver Creek, gaging station records...........

Bibliography, selected............................

Birdsview, Wash., floodmarks...............

Brooks, Dr. Charles F. quoted.

Cascade River, course.

discharge data. gaging-station records

Chinook.

Climate

Concrete, Wash., flood data

floodmarks precipitation records

Damage, flood.

$3,18-20$

Darrington, Wash., flood data.

temperature and precipitation.

Day Creek, gaging-station records for.

Delta of the Skagit River.

Diablo Dam.

Diablo Dam weather station, precipitation records.

13,14

Diablo Reservoir..................... 5, 14, 15-16, 37

Dikes_............................... 17, 18, 29, 30-31

Drainage, area............................... 1, 5-6

changes in

East Fork Nookachamps Creek, gaging-station records for

52

Flood data, historical

22-25

Flood-frequency curves

60-61

Flood peaks, duration of

11-14

effect of precipitation on

11-14

See also Gaging-station records.

Flood photographs. 4 , pls. 3,4

Flood plain

Flood profiles.

Flood records, combining records

kinds

mean annual.............................. 57-58

tests for homogeneity.

Floods, December 1917.

$2,22,29$

December 1921

$3,22,29$

description

9-18

February 1932,...................... 3, 22, 29-30

February 1951

13-14, 17, 22,30-31
Floods, December 1917-Continued

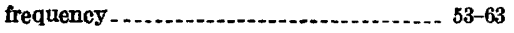
For detailed listings see under Frequency of floods.

Indian legend of 1815 . . . . . . .

long-duration............................... 13-14

November 1897. ....................... 2, 21, 27

November 1896..................... 2, 21

November 1906........................ 2,22

November 1909..................... 2, 22, 28-29

November 1949................... 3, 11-13, 22, 30

short-duration.............................. 11-13

summer.................................... 11, 27

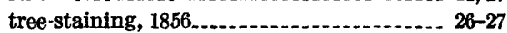

types........................................ 9

Frequency of floods, annual flood series....... 54

partial-duration series....................... 54

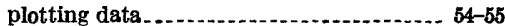

plotting the frequency curve.............. 56

recurrence intervals....................... 54,55

regional ................................ $56-57$

relationships................................... $59-60$

selecting base period....................... $\quad 57$

undesirable use of single station record.... 63

Gaging-station records......................... 31-53

Geography...................... 4-6

Glacier Peak. . . .

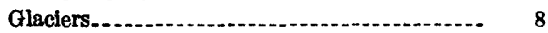

Gorge dam and powerplant.................. 5

Historical data, value.......................... 55-56

History, geologic . ........... 8

of floods............................. 2-3, 20-22

of settlement................................ 2,20

Hydroelectric-power project................. 5

Introduction................................... 1-4

Marblemount, Wash., flood data.............. 23 precipitation records....................... 13, 14

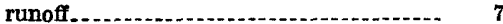

Mean annual flood, comparison of means.... $\quad 57$ defined................ 55

Newhalem, flood of 1909................... 29, 30

Powerplants

Precipitation............................. 6-8, 10,11-14

Precipitation records...................... 7, 13, 14, 21

Previous investigations........................ 3-4, 10

Purpose of this report .......... 3

Reflector Bar, flood data ....................... 23

floodmarks........................ 25-26, 27, 28

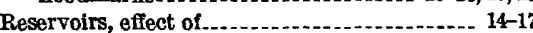


Winter floods, cause

dates of occurrence . . ..................... 10

runoff....................................... 10

shape of profile.......................... 11, 12, 13 